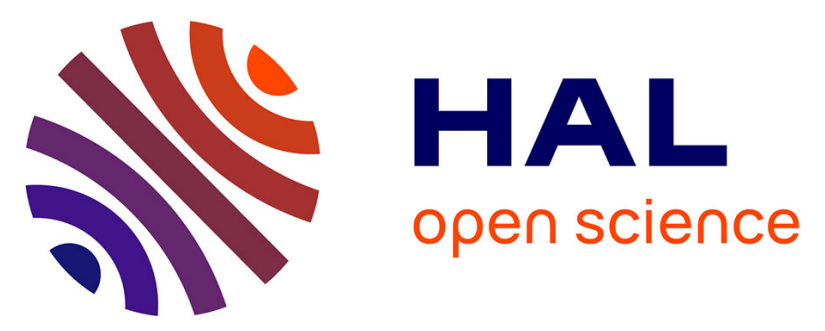

\title{
Exhumation history of the deepest central Himalayan rocks, Ama Drime range: Key pressure-temperature-deformation-time constraints on orogenic models
}

E. Kali, P.H. Leloup, Nicolas Arnaud, G. Maheo, Dunyi Liu, E. Boutonnet, J. van Der Woerd, Xiaohan Liu, Jing Liu-Zeng, Haibing Li

\section{To cite this version:}

E. Kali, P.H. Leloup, Nicolas Arnaud, G. Maheo, Dunyi Liu, et al.. Exhumation history of the deepest central Himalayan rocks, Ama Drime range: Key pressure-temperature-deformation-time constraints on orogenic models. Tectonics, 2010, 29, pp.TC2014. 10.1029/2009TC002551 . hal-00486405

\section{HAL Id: hal-00486405 https://hal.science/hal-00486405}

Submitted on 30 Apr 2021

HAL is a multi-disciplinary open access archive for the deposit and dissemination of scientific research documents, whether they are published or not. The documents may come from teaching and research institutions in France or abroad, or from public or private research centers.
L'archive ouverte pluridisciplinaire HAL, est destinée au dépôt et à la diffusion de documents scientifiques de niveau recherche, publiés ou non, émanant des établissements d'enseignement et de recherche français ou étrangers, des laboratoires publics ou privés. 


\title{
Exhumation history of the deepest central Himalayan rocks, Ama Drime range: Key pressure-temperature-deformation-time constraints on orogenic models
}

\author{
E. Kali, ${ }^{1}$ P. H. Leloup, ${ }^{2}$ N. Arnaud, ${ }^{3}$ G. Mahéo, ${ }^{2}$ Dunyi Liu, ${ }^{4}$ E. Boutonnet, ${ }^{2}$ \\ J. Van der Woerd, ${ }^{1}$ Xiaohan Liu, ${ }^{5}$ Jing Liu-Zeng, ${ }^{5}$ and Haibing $\mathrm{Li}^{4}$ \\ Received 8 June 2009; revised 26 September 2009; accepted 21 October 2009; published 14 April 2010.
}

[1] The Ama Drime range located at the transition between the high Himalayan range and south Tibet is a $\mathrm{N}-\mathrm{S}$ active horst that offsets the South Tibetan Detachment System (STDS). Within the horst, a paragneissic unit, possibly attributed to the upper Himalayan crystalline series, overly the lower Himalayan crystalline series Ama Drime orthogneissic unit containing large metabasite layers and pods that have experienced pressure $\geq 1.4 \mathrm{GPa}$. Combining structural analysis with new and published pressure-temperature $(\mathrm{P}-\mathrm{T})$ estimates as well as $\mathrm{U}-\mathrm{Th} / \mathrm{Pb},{ }^{39} \mathrm{Ar} /{ }^{40} \mathrm{Ar}$ and $(\mathrm{U}-\mathrm{Th}) / \mathrm{He}$ ages, the P-T-deformation-time (P-T-D-t) paths of the main units within and on both sides of the horst are reconstructed. They imply that $\mathrm{N}-\mathrm{S}$ normal faults initiated prior to $11 \mathrm{Ma}$ and have accounted for a total exhumation $\leq 0.6 \mathrm{GPa}(22 \mathrm{~km})$ that probably occurred in two phases: the first one until $\sim 9 \mathrm{Ma}$ and the second one since 6 to $4 \mathrm{Ma}$ at a rate of $\sim 1 \mathrm{~mm} / \mathrm{yr}$. In the Ama Drime unit, 1 to $1.3 \mathrm{GPa}$ ( 37 to $48 \mathrm{~km}$ ) of exhumation occurred after partial melting since $\sim 30 \mathrm{Ma}$ until $\sim 13 \mathrm{Ma}$, above the Main Central Trust (MCT) and below the STDS when these two fault systems were active together. The switch from E-W (STDS) to N-S (Ama Drime horst) normal faulting between 13 and $12 \mathrm{Ma}$ occurs at the time of propagation of thrusting from the MCT to the Main Boundary Thrust. These data are in favor of a wedge extrusion or thrust system rather than a crustal flow model for the building of the Himalaya. We propose that the kinematics of south Tibet Cenozoic extension phases is fundamentally driven by the direction and rate of India underthrusting. Citation: Kali, E., P. H. Leloup, N. Arnaud, G. Mahéo, D. Liu, E. Boutonnet, J. Van der Woerd, X. Liu, J. Liu-Zeng, and H. Li

\footnotetext{
${ }^{1}$ Institut de Physique du Globe de Strasbourg, UMR 7516, UDS, EOST, CNRS, Strasbourg, France.

${ }^{2}$ LST, UMR 5570, Université de Lyon, ENS Lyon, UCB Lyon1, CNRS, Villeurbanne, France.

${ }^{3}$ Géosciences Montpellier, Université de Montpellier 2, Montpellier, France.

${ }^{4}$ Laboratory of Continental Dynamics, Institute of Geology, CAGS, Beijing, China.

${ }^{5}$ Institute of Tibetan Plateau Research, Chinese Academy of Sciences, Beijing, China.
}

Copyright 2010 by the American Geophysical Union. 0278-7407/10/2009TC002551
(2010), Exhumation history of the deepest central Himalayan rocks, Ama Drime range: Key pressure-temperature-deformationtime constraints on orogenic models, Tectonics, 29, TC2014, doi:10.1029/2009TC002551.

\section{Introduction}

[2] Synconvergence arc-parallel and arc-perpendicular extension phases have taken place in mountain ranges such as the Himalaya-Tibet and the Alps, focusing the attention of many scientists that discuss their rheological and/or kinematics significance. In the Himalaya-Tibet orogen, arcperpendicular extension is mostly related to Miocene top-tothe-north normal faulting along the South Tibetan Detachment System (STDS) [Burg et al., 1984; Burchfiel et al., 1992]. This structure has been linked either to gravitational collapse of the range [Dewey, 1988], or thrusting of Himalayan crystalline slab (HCS) above the Main Central Trust (MCT). Some authors consider that the HCS was extruded in a thrust wedge [i.e., Burchfiel and Royden, 1985; Grujic et al., 1996; Guillot and Allemand, 2002, Webb et al., 2007], while other make it a result of ductile channel flow [Nelson et al., 1996; Beaumont et al., 2001; Jamieson et al., 2004]. Arc parallel extension is accommodated by numerous $\mathrm{N}-\mathrm{S}$ trending normal faults that affect south Tibet with few of them extending across the high Himalayan chain [Molnar and Tapponnier, 1978; Tapponnier et al., 1981; Armijo et al., 1986]. Such extension has been attributed either to dissipation of excess potential energy accumulated, either during the thickening of the Asian margin [Molnar and Tapponnier, 1978] or during uplift of the plateau following detachment of the upper mantle part of the Asian lithosphere [e.g., England and Houseman, 1989], or to accommodation of boundary forces and displacements [e.g., Armijo et al., 1986; Yin, 2000; Tapponnier et al., 2001].

[3] In a few localities, such as the Nyainqentanglha graben [Pan and Kidd, 1992], the Gurla-Mandata dome [Murphy et al., 2002], the Lunggar rift [Kapp et al., 2008], and Dinggye rift [e.g., Burchfiel et al., 1992] ductile deformation related to $\mathrm{N}-\mathrm{S}$ active normal faults has been observed. Most authors consider that ductile and brittle structures are related to the same, continuous extension phase [Harrison et al., 1995; Kapp et al., 2008; Cottle et al., 2009]. However, initiation of normal faulting in the KungCo graben has been dated at $\leq 4 \mathrm{Ma}$, implying that two successive arc-perpendicular extension episodes may have taken place in south Tibet, one around 10-12 Ma and another since 4-6 Ma [Mahéo et al., 2007]. 


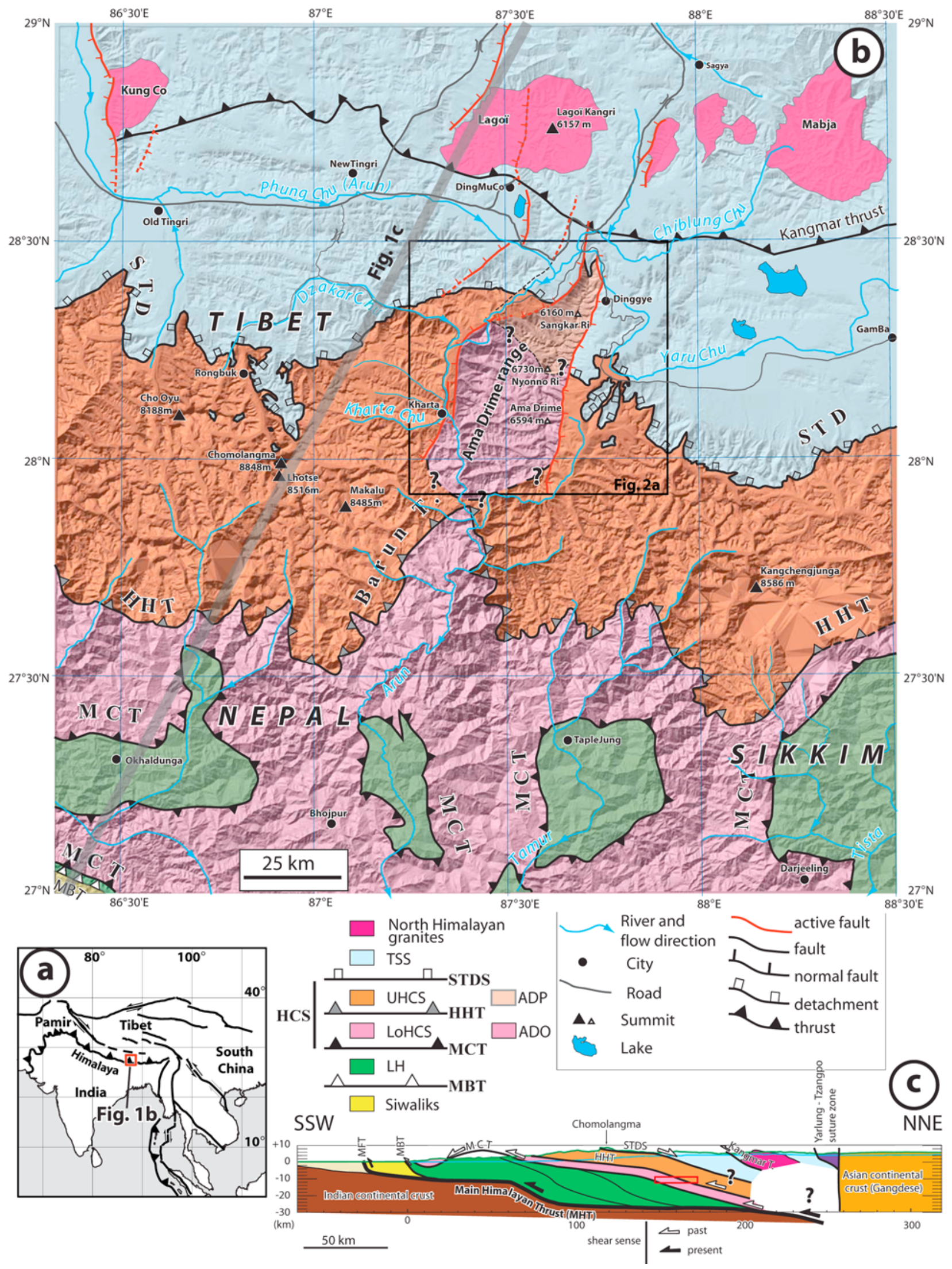

Figure 1 
[4] In order to quantify the amount and clarify the mechanisms of rock exhumation in the HCS and to constrain the timing of arc-perpendicular and arc-parallel extensions in south Tibet, we performed a detailed structural, petrologic and thermochronologic study of the Ama Drime range located at the southern end of the Xainza-Dinggye rift. The targeted area is located northeast of the ChomolangmaMakalu massif of the Himalayan range (Figure 1). The Ama Drime range is a key area for at least four reasons. (1) The Ama Drime is located at the transition between the high chain and the Tibetan Plateau, where the STDS is crosscut by $\mathrm{N}-\mathrm{S}$ active normal faults (Figure 1b), allowing assessment of the relative and absolute timing of these structures. (2) Arc-parallel extension is in brittle and ductile domains so that the continuity of the deformation can be addressed. (3) The Ama Drime range contains the only eclogite found so far in the central Himalayas [Lombardo and Rolfo, 2000; Groppo et al., 2007] implying exhumation of deep-seated rocks that can be used to quantify the magnitudes of vertical and horizontal movements between the MCT and the STDS. (4) The Arun-Phung Chu river that flows along the Ama Drime, is one of the few rivers that leaves the Tibetan Plateau by crossing the central Himalayan chain in between the syntaxes, bringing up the issue of the relation between erosion and exhumation.

[5] Our integrated approach combining structural geology, geomorphology, petrography and multimethod geochronology aims at deciphering and quantifying the structural history of the Ama Drime area and the pressure-temperaturetime $(\mathrm{P}-\mathrm{T}-\mathrm{t})$ evolution of the continental crust, to bring important constraints on orogenic lithospheric deformation models.

\section{Geological Setting}

[6] Near the Tibet-Nepal-Sikkim borders a $\sim 150 \mathrm{~km}$ stretch of the Himalayan range encompass 4 of the 5 highest summits on Earth, including the Chomolangma (Everest) (8848 $\mathrm{m}$ above sea level (asl), Figure 1b). The Arun-Phung Chu river, flowing toward the south from Tibet, has cut down to $\sim 2200 \mathrm{~m}$ asl across the range, less than $30 \mathrm{~km}$ away from the Makalu summit ( $8485 \mathrm{~m}$ asl) (Figure 1b). Headward, the Arun River is flowing along the western flank of the Ama Drime range, the only significant topographic range protruding from the Himalaya to the north (Figure 1b).

[7] The north-south Arun valley provides a complete geological cross section across the central Himalayas. The main lithotectonic units define stripes, more or less parallel to the range, dipping to the north and separated by major tectonic contacts (Figure 1b). The central unit, the Himalayan crystalline series (HCS) is a sliver of gneiss and granites, sandwiched between less metamorphosed rocks (Figures 1b and 1c). To the bottom (south) the HCS rests on the phyllites and quartzites of the Lesser Himalaya (LH, Tumlingtar unit of Lombardo et al. [1993]). To the top (north) the HCS is separated from the weakly metamorphosed Tethyan sedimentary series (TSS) by the South Tibetan Detachment (STD).

[8] There has been debate on the internal lithotectonic subdivision of the HCS. Within the Arun area two main lithotectonic units have been distinguished within the HCS [e.g., Bordet, 1961; Brunel, 1983; Groppo et al. 2007]: the Lesser and Greater Himalayan crystalline sequences (LHCS and GHCS, respectively). The base of the GHCS corresponds to a thrust zone, locally termed "Barun thrust" whose hanging wall is marked by discontinuous exposure of the Barun orthogneiss [Brunel, 1983]. That thrust zone has been considered by some as the main central thrust (MCT of Brunel [1983] and Goscombe and Hand [2000]). Goscombe et al. [2006] also consider it as the main structure of the belt and termed it "High Himal Thrust" (HHT) (Figure 1b). Most of the GHCS consists of paragneiss and amphibolites, often migmatitic [Brunel, 1983; Lombardo et al., 1993], intruded by Miocene leucogranites including huge laccolithes such as the Makalu-Cho Oyu leucogranite [e.g., Borghi et al., 2003]. Toward the top of the GHCS all rocks, except very few late dikes, are affected by top-to-the-northeast, ductile shearing in the STD shear zone [Burg et al., 1984; Burchfiel et al., 1992; Carosi et al., 1998; Cottle et al., 2007].

[9] Below the GHCS, the LHCS is mostly composed of metapelites overlying the Num/Ulleri orthogneiss [Bordet, 1961; Brunel, 1983; Goscombe et al., 2006]. The LHCS series belong in fact to two distinct basinal sequences deposited on the Indian passive margin, the Mesoproterozoic

Figure 1. Structure of the central high Himalayas. (a) Simplified geological frame of the India-Asia continental collision. (b) Simplified structural map of the Himalayas between the Cho Oyu and the Kangchengjunga. Shaded SRTM DEM is shown in background by transparency. The South Tibet Detachment (STD) and the north Himalayan domes have been mapped from the interpretation of Landsat 7 satellite data checked against personal field observations and published maps [e.g., Burchfiel et al., 1992; Carosi et al., 1998; Searle, 2007]. The HHT (Barun thrust) and MCT are from Goscombe et al. [2006] and Harris et al. [2004]. Active faults appear in red and are from Armijo et al. [1986], Landsat 7 satellite data interpretation, and field observations. Projection is UTM 45. The gray thick line corresponds to the trace of Figure 1c cross section. (c) Simplified generalized cross section of the Himalayas. NNE-SSW interpretative cross section at $\sim 87^{\circ} \mathrm{E}$, few kilometers west of the Ama Drime range. Main geological units are as in Figure 1b, and main structures geometry is from Bollinger et al. [2004]. The green line corresponds to the upper relief (i.e., Chomolangma), and the blue line corresponds to the lower relief (i.e., Arun valley); no vertical exaggeration. The box indicates the approximate location of the Ama Drime rock before their exhumation in the horst (see Figure 12b). TSS, Tethyan sedimentary series; HCS, Himalayan crystalline series, UHCS, upper Himalayan crystalline series; LoHCS, lower Himalayan crystalline series; LH Lesser Himalaya series; ADP, Ama Drime paragneisses; ADO, Ama Drime orthogneisses; STDS, South Tibet Detachment System; HHT, High Himal Thrust; MCT, Main Central Thrust; MBT, Main Boundary Thrust; see section 2 for definitions. 
Lesser Himalayan Sequence and the NeoproterozoicCambrian Greater Himalayan Sequence, separated by the Himalayan unconformity (HU) [Goscombe et al., 2006]. The LHCS is strongly deformed, is bounded at its base by mylonites and thrust sheets [Bordet, 1961; Meier and Hiltner, 1993], and has often been referred as the MCT zone. The basal contact of the LHCS will be referred here as the Main Central Thrust or MCT (MCT2 of Arita [1983], MCT of Heim and Gansser [1939], Le Fort [1975], DeCelles et al. [2001], and Goscombe et al. [2006]).

[10] In order to avoid the ambiguities resulting from various definitions of the MCT and of the GHCS and LHCS series we use in the following a structural terminology: the upper Himalayan crystalline series (UHCS) corresponds to the series bounded at their top by the STDS and at their bottom by the HHT as mapped by Goscombe et al. [2006] (Figure 1b). The lower Himalayan crystalline series (LoHCS) are bounded at their top by the HHT and are their bottom by the MCT as mapped by Goscombe et al. [2006] (Figure 1b).

[11] In map view, the range-parallel orientation of the MCT and parallel thrusts are locally sinuous, particularly around the main rivers flowing down from the Himalayas (Figure 1b). Along the Arun River, such map pattern is attributed to the Arun anticline with a $\sim \mathrm{N}-\mathrm{S}$ axis [Bordet, 1961], and some [e.g., Borghi et al., 2003; Liu et al., 2007] have interpreted the Ama Drime range as the northern prong of the Arun anticline. There is still considerable debate whether the main structures can be traced at the scale of the whole orogen but one possible interpretation is that two main thrusts can be traced for several hundreds of kilometers: the upper MCT (MCTu, joining the Vaikrita, Mahbharat, Chomrong, Barun, HHT and Kakhtang thrusts) and the lower MCT (MCTl joining the Ramgarh and Munsiari thrusts).

\section{Geology and Structure of the Ama Drime Range and the Dinggye-Kharta Area}

\subsection{Topography, Morphology, and Active Tectonics}

[12] The Ama Drime range exhibits a double-crested horst morphology that is mostly controlled by active normal faults [Armijo et al., 1986]. The range displays several peaks over $6000 \mathrm{~m}$ asl, the highest being the Nyonno Ri (6730 m asl) (Figures $2 \mathrm{a}$ and $\mathrm{S} 1$ in the auxiliary material). ${ }^{1}$ To the east, the range shows for more than $50 \mathrm{~km}$ a very steep linear

\footnotetext{
${ }^{1}$ Auxiliary materials are available in the HTML. doi:10.1029/ 2009TC002551.
}

NNE-SSW crest at 5000 to $6700 \mathrm{~m}$ asl. This 500 to $1000 \mathrm{~m}$ high wall is bounded by a $\sim 50^{\circ}$ east dipping active normal fault, the Dinggye fault, whose recent activity is attested by spectacular triangular facets and offset moraine ridges [Armijo et al., 1986; Zhang and Guo, 2007] (Figure 3a). To the west, the Arun River flows parallel to the west dipping Kharta active normal fault (Figure 2a). The active fault length is shorter $(\sim 30 \mathrm{~km})$ than the Dinggye fault and the elevation of the western Ama Drime crest is slightly lower than to the east, but the flank is steeper and the activity of the fault attested by $\sim 1500 \mathrm{~m}$ high triangular facets, fluvial terraces and moraines offsets (Figures $3 \mathrm{~b}$ and $3 \mathrm{c}$ ).

[13] On both sides of the range, quartz cataclasite outcrops on the topographic scarps (Figures $3 \mathrm{a}$ and $3 \mathrm{c}$ ). Brittle faults strike almost $\mathrm{N}-\mathrm{S}$ and generally dip steeply $\left(\sim 45\right.$ to $55^{\circ}$ on average) to the west on the western side of the range and to the east on the eastern one, in good accordance with the geometry of the active faults deduced from the morphology (Figures 2a, 4e, 4f, 4g, 4h, 4k, and 4m). Slickensides when present indicate almost pure dip slip motions (Figure 4). On the eastern side of the range, normal faults parallel to the Dinggye fault slice the foothills to at least $5 \mathrm{~km}$ away from the topographic front and have tilted to the west the metamorphic series of the STD shear zone (Figure 2b, top).

[14] At the northern end of the range, the Sangkar fault exhibits clear evidences for recent activity with triangular facets and fault scarps (Figure 3d). It is probable that the Sangkar and Kharta active faults are linked by an $\sim \mathrm{E}-\mathrm{W}$ active fault [Armijo et al., 1986]. At the northern end of the Kharta fault, the Arun-Phung Chu river has a very peculiar course: it enters within the footwall of the active fault, where it carves deep gorges and turns around the Yo Ri promontory before exiting in the Kharta basin (Figure 2a). This fact was already noticed by Wager [1937], who interpreted the river to be antecedent to the building of the high relief of the Ama Drime, while Armijo et al. [1986] interpreted that pattern as resulting from the capture of the Phung Chu by the Arun River.

[15] While the eastern and western crest of the Ama Drime have almost the same altitude, the water divide is located along the eastern one (Figure 2a), highlighting a profound asymmetry in recent tectonics and/or erosion that may be in part induced by the Arun River down cutting.

[16] The Ama Drime area shows a relatively high microseismic level documented both by the seismic network of Nepal [Pandey et al., 1995; Cattin and Avouac, 2000] and by temporary seismic networks in Nepal and southern Tibet [Monsalve et al., 2006]. In the south of the Ama Drime area, all instrumental $M \geq 5$ and part of the $2 \leq M \leq 4$ earthquakes occur at depths $\geq 50 \mathrm{~km}$, and are thought to take place in the lower Indian crust and upper mantle as a result of continuous

Figure 2. Structure of the Ama Drime Range. (a) Structural map of the Dinggye-Kharta area corresponding to the frame on Figure 1b. Drawn from satellite image interpretation and fieldwork. Projection is UTM45. The Kartha-Saer unit is attributed to the upper Himalayan crystalline series while the Ama Drime orthogneisses are attributed to the lower Himalayan crystalline series (see text). Structural observations are reported as well as samples discussed in this study. For other sample locations, see Figure S1. Each lettered black box corresponds to a stereonet (Figure 4). Sections A-B and C-D (Figure 2b) are located. (b) Geological schematic cross sections of both flanks of the Ama Drime range. Cross sections located on Figure 2a. Drawn from field observations (see text and Figure 3). No vertical exaggeration. 


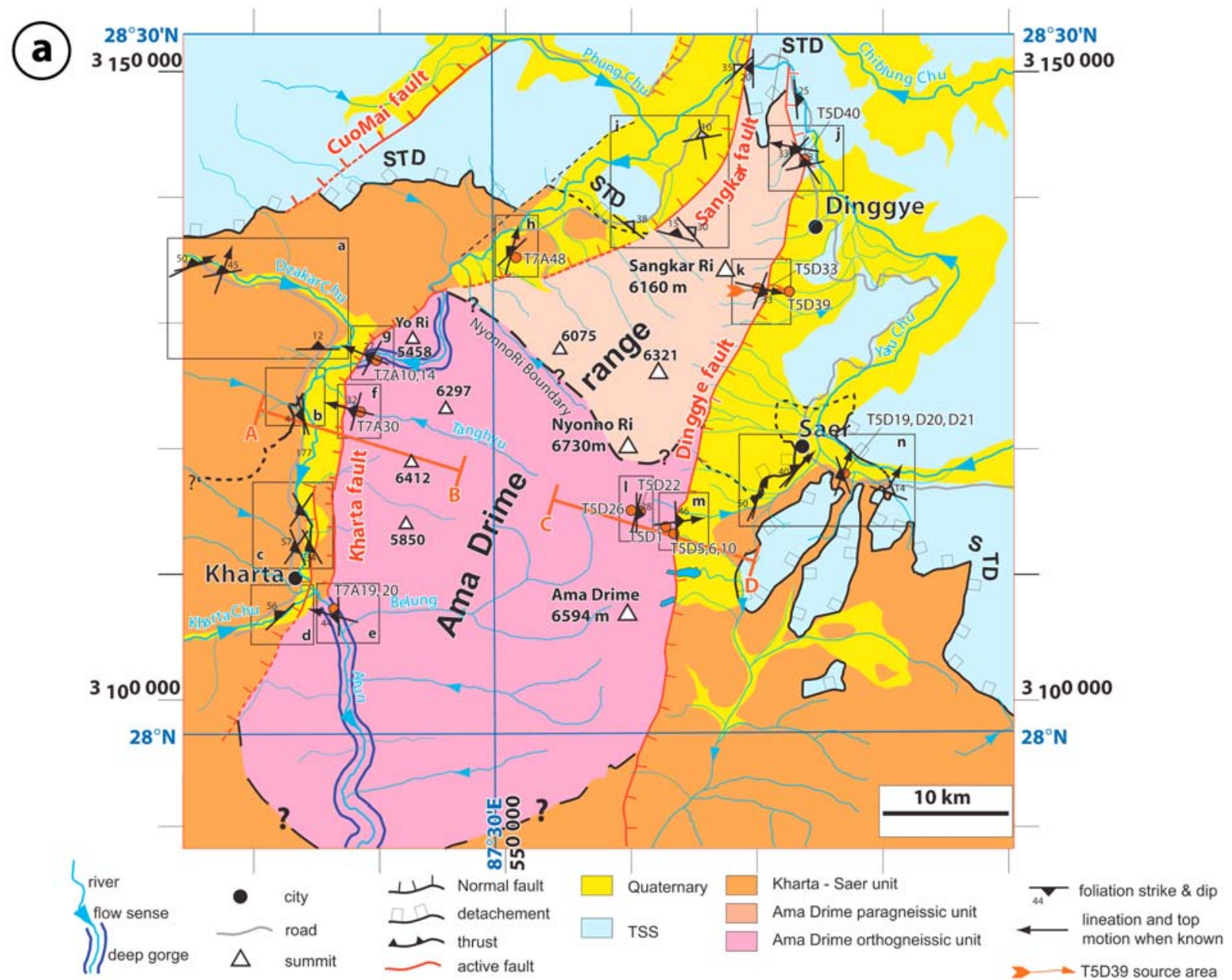

(b)
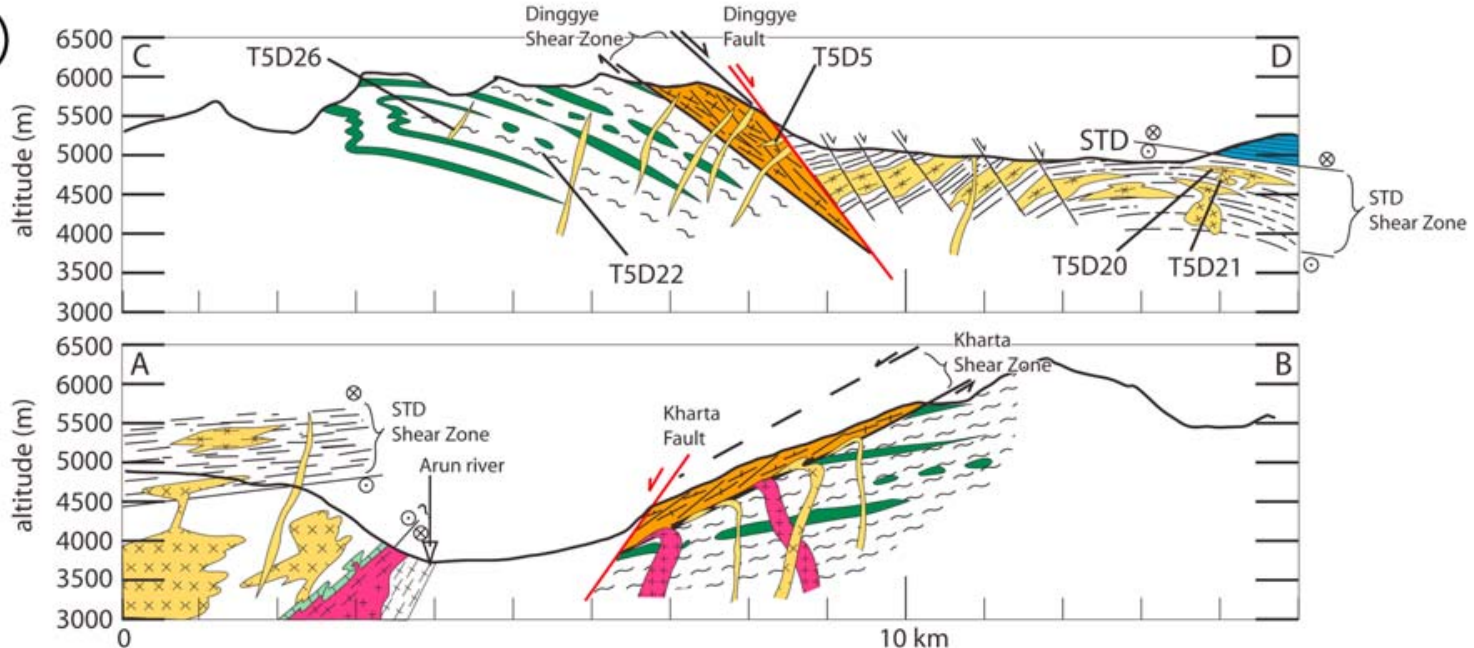

E - Migmatitic orthogneiss $x \times x$ Mylonites

ETID Grey granite

XXX Kharta gneiss

Amphibolite/Biotitite
Tethyan series

$\square$ Late leucogranite dyke
$\square \times x$ Miocene leucogranite
3 Deformed Miocene leucogranite

Figure 2 
subduction and eclogitization [Monsalve et al., 2006; Schulte-Pelkum et al., 2005; Baur, 2007]. In the north, earthquakes are much shallower (depth $\leq 25 \mathrm{~km}$ ) and have focal mechanisms compatible with north-south trending normal faulting. This seismic activity occurs on active normal faults that connect the Ama Drime horst to the Xainza rift located north of the Yarlung-Tsanpo suture zone [Pandey et al., 1999; Monsalve et al., 2006].

[17] The Ama Drime range is thus an active horst bounded by two conjugate active normal fault systems, at the southern end of the Xainza-Dinggye fault system [e.g., Armijo et al., 1986].

\subsection{Rock Lithology, Structures, and Microstructures}

[18] Three main lithologic units can be distinguished in the study area. (1) The Kharta-Saer unit, mostly composed of metasedimentary rocks and rare amphibolites intruded by numerous leucogranites. This unit includes the STD shear zone and the Kharta gneiss. (2) The Ama Drime orthogneissic unit, which mainly consists in granitic gneisses and migmatites embedding numerous metabasic layers and pods. (3) The Ama Drime paragneissic unit localized above the Ama Drime orthogneissic unit, which is mostly represented by paragneisses and pelitic schists. Leucogranite dikes crosscut all units (Figures $2 \mathrm{a}$ and $2 \mathrm{~b}$ ).

\subsubsection{South Tibetan Detachment and Shear Zone}

[19] Near the Ama Drime range, the STD has been described across the Dzakar river [Burg et al., 1984; Cottle et al., 2007], and south of Dinggye [Burchfiel et al., 1992; Leloup et al., 2009, 2010]. The STD separates deformed garnet-micaschists and leucogranites of the UHCS characterized in the STD shear zone (STDSZ) by $\sim \mathrm{E}-\mathrm{W}$ foliations gently dipping to the north, NE trending lineation and normal (top-to-the-north) sense of shear, from weakly metamorphosed Tethyan sedimentary series above. In the STDSZ, few undeformed leucogranites postdating deformation have also been observed [Leloup et al., 2009, 2010]. As the foliation dips gently, there is no access to a complete section of the STDSZ near Saer and its total thickness cannot be assessed. However, along other sections, as near Rongbuk or at the top of the Kula Kangri leucogranite, the STDSZ is typically 200 to $300 \mathrm{~m}$ thick [Murphy and Harrison, 1999; Edwards et al., 1996]. $100 \mathrm{~m}$ below the STD, garnet-micaschists of the STDSZ are characterized by the transition from a staurolite-garnet paragenesis (prekynematic?) to sillimanite-garnet (synkinematic) assemblage [Leloup et al., 2009, 2010]. The corresponding P-T evolution constrained by pseudosections and garnet isopleths, is characterized by a peak pressure of $\sim 0.6 \mathrm{GPa}$ $(\sim 22 \mathrm{~km})$ and $550^{\circ} \mathrm{C}$ followed by a slight heating and decompression until $\sim 0.45 \mathrm{GPa}(\sim 27 \mathrm{~km})$ and $\sim 625^{\circ} \mathrm{C}$, preceding a phase of decompression and cooling (Figure 5c) [Leloup et al., 2009, 2010].

[20] Combining published observations, fieldwork, and Landsat satellite image interpretation, Leloup et al. [2010] propose a map of the STD (Figure 2a). This mapping confirms that the STD dipping $\sim 10 \pm 5^{\circ}$ to the NNE, is deflected to the north around the Ama Drime range, and is cut and offset by the N-S active normal faults. The apparent horizontal offsets of the STD are of $35 \pm 5 \mathrm{~km}$ along the

Figure 3. Figures 3a-3d are field pictures of active faults bounding the Ama Drime Range. (a) Triangular facets along the Dinggye active normal fault. View toward west. The closest facet is $\sim 500 \mathrm{~m}$ high. The two converging black arrows indicate the fault trace. White arrow points to quartz cataclasites whose fault surface strikes N06 49E. Nyonno Ri summit (6730 m) in the background. (b) Triangular facets along the Kharta active normal fault. View toward east. In the background, black arrows indicate the trace of the east branch of the Kharta active fault. Facets are $\sim 1300 \mathrm{~m}$ high above the arrows. In the foreground, white arrows indicate the trace of the west branch of the Kharta fault offsetting alluvial terraces of the Kharta Chu. (c) Along-strike view of the north Kharta active normal fault. View toward the SSW from north of the outlet of the upper Arun gorges. White arrows point to a $100 \mathrm{~m}$ high offset of an alluvial terrace. Outcrop in the foreground is a fault surface striking N15 55W at the top of quartz cataclasites. (d) Sangkar active normal fault. View toward the SE. Trace of the STD on the northern Ama Drime crest is drawn. The two converging black arrows indicate the fault trace. The Sangkar Ri summit $(6160 \mathrm{~m})$ sticks out in the background. An enlargement of this summit from a different point of view shows UHCS series gently dipping to the north. Figures $3 \mathrm{e}-3 \mathrm{~h}$ are field pictures orthogneisss of the Ama Drime south of the Nyonno Ri. (e) Folded basic layers within migmatites south of the Nyonno Ri. The cliff is $\sim 400 \mathrm{~m}$ high. The fold axes trend $\sim \mathrm{N}-\mathrm{S}$. (f) Cliff north of the Ama Drime summit showing leucocratic dikes cutting across previous foliation including boudinaged basic layers (inset with dikes highlighted in white). The visible part of the cliff is $\sim 500 \mathrm{~m}$ high. View toward the south. (g) Basic enclave within migmatite. Hammer for scale. Note centimeter-scale garnets in basic level (inset). Migmatitic sample T5D22 comes from this outcrop. (h) Basic layer within migmatites crosscut by a leucocratic pegmatitic dike (LD, sample T5D26). Figures $3 \mathrm{e}, 3 \mathrm{~g}$, and $3 \mathrm{~h}$ are from a glacial valley south of the Nyonno Ri (zone 1 , Figure 2a). Figures 3i-3m are field pictures normal shear zones on both side of the Ama Drime range. (i) Chlorite-grade C/S deformation in orthogneiss showing top-to-the-east normal motion. Footwall of Dinggye normal fault. Glacial valley south of the Nyonno Ri summit (zone m, Figure 2a). See Figure $4 \mathrm{~m}$ for foliation and lineation attitude. (j) Late leucocratic dike (LD, sample T5D5) crosscutting mylonitic orthogneiss (sample T5D6). Footwall of Dinggye normal fault. Hammer gives scale. Glacial valley south of the Nyonno Ri summit (zone m, Figure 2a). (k) Close-up of Figure 3j mylonitic orthogneiss, showing top-to-the-east (normal) shear sense. Hammer gives scale. See Figure $4 \mathrm{~m}$ for foliation and lineation attitude. (l) Mylonitic orthogneiss and biotite-rich enclave. Knife gives scale. Footwall of Kharta normal fault in Arun-Phung Chu gorges (zone g, Figure 2a). Shear planes indicate top-to-the-west (normal) shear sense. See Figure 4g for foliation and lineation attitude. $(\mathrm{m})$ Stretched remnants of tourmaline bearing leucocratic dikes. Hammer gives scale. Footwall of Kharta normal fault in Arun-Phung Chu gorges (zone g, Figure 2a). 
Dinggye active normal fault, and of $\sim 15 \mathrm{~km}$ across the Sangkar fault (Figure 2a), which correspond to vertical offsets of 4.4 to 9.4 and 1.3 to $4 \mathrm{~km}$, respectively [Leloup et al., 2009, 2010].

[21] At the scale of the orogen the STD is broadly located at the transition between the Tibetan Plateau and the high Himalayan chain. However, it has no clear morphological expression, it is crosscut by active N-S normal faults and no crustal earthquake indicative of $\sim \mathrm{E}-\mathrm{W}$ normal faulting has been reported. The STD is thus a fossil structure.

\subsubsection{Kharta Area}

[22] Along the Dzakar-Phung Chu valley, $\sim 12 \mathrm{~km}$ south of the STD $(\sim 8 \mathrm{~km}$ below), foliations dip to the west (Figures 2a, 4b, 4c, and 4d). In this area the main lithologies are garnet bearing metapelites, often migmatitic, associated with minor orthogneiss, metabasite and calcsilicate rocks.
These lithologies are named the Kartha gneiss and attributed to the GHCS (our UHCS) by Borghi et al. [2003] that document an adiabatic decompression from $\sim 0.8 \mathrm{GPa}$ and $\sim 700^{\circ} \mathrm{C}$, prior to a roughly isobaric cooling at $\sim 0.2 \mathrm{GPa}$ (Figure 5a). Several generations of leucosomes are conspicuous, ranging from concordant leucogranitic Gt-Sill orthogneiss to discordant cordierite bearing leucogranite veins and pods [Borghi et al., 2003]. All these rocks are crosscut by Miocene tourmaline leucogranitic dikes [Visonà and Lombardo, 2002]. North of Kharta a large granite body that crosscuts the gneiss is overlaid by a west dipping shear zone with N-S lineations (Figure 4b). The Kharta gneiss exhibits either no lineation or $\mathrm{N}-\mathrm{S}$ to $\mathrm{NE}-\mathrm{SW}$ trending lineations (Figures 2a, 4c, and 4d). In the absence of clear shear criteria it is difficult to relate this deformation to a precise tectonic episode.
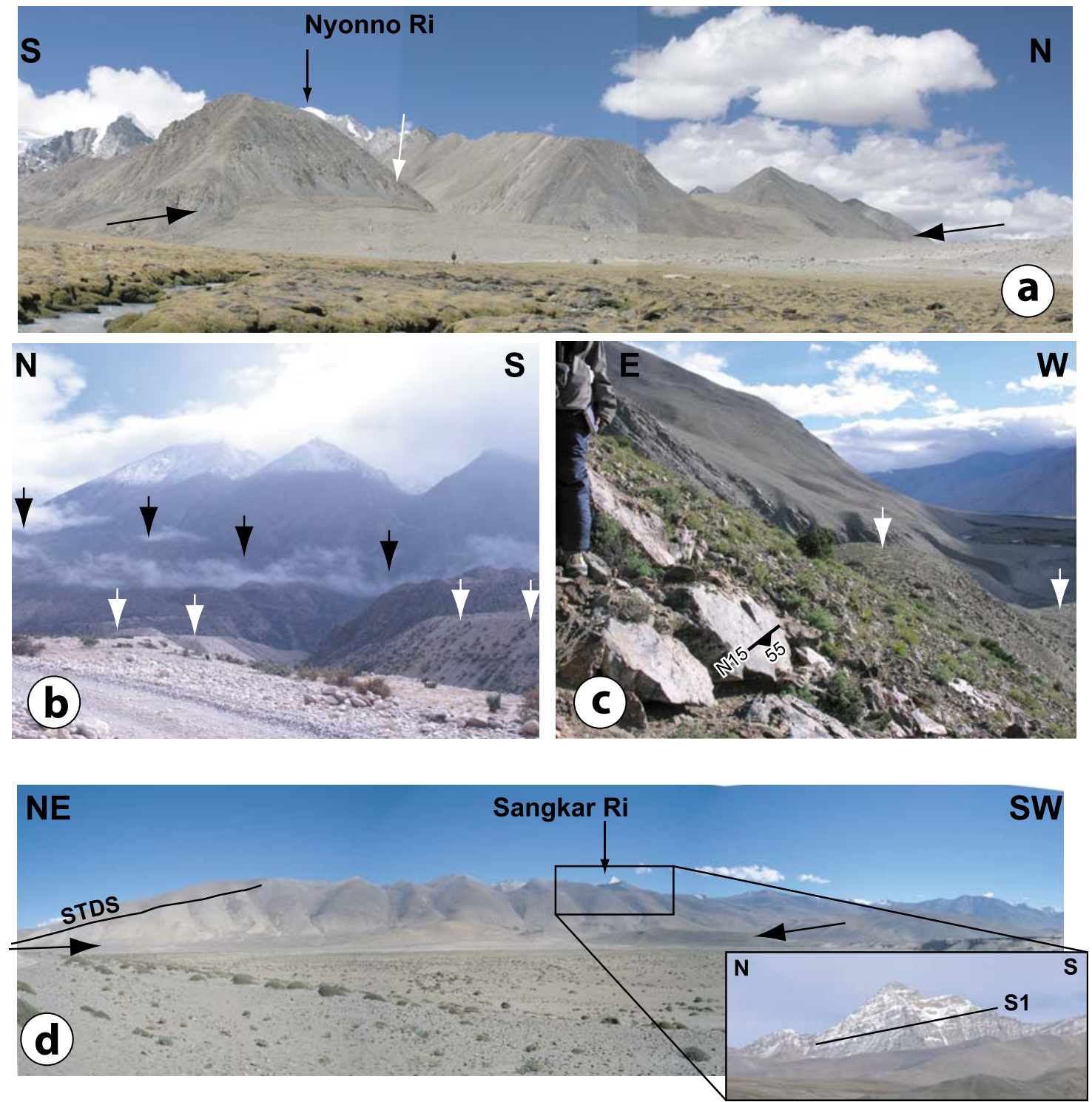

Figure 3 


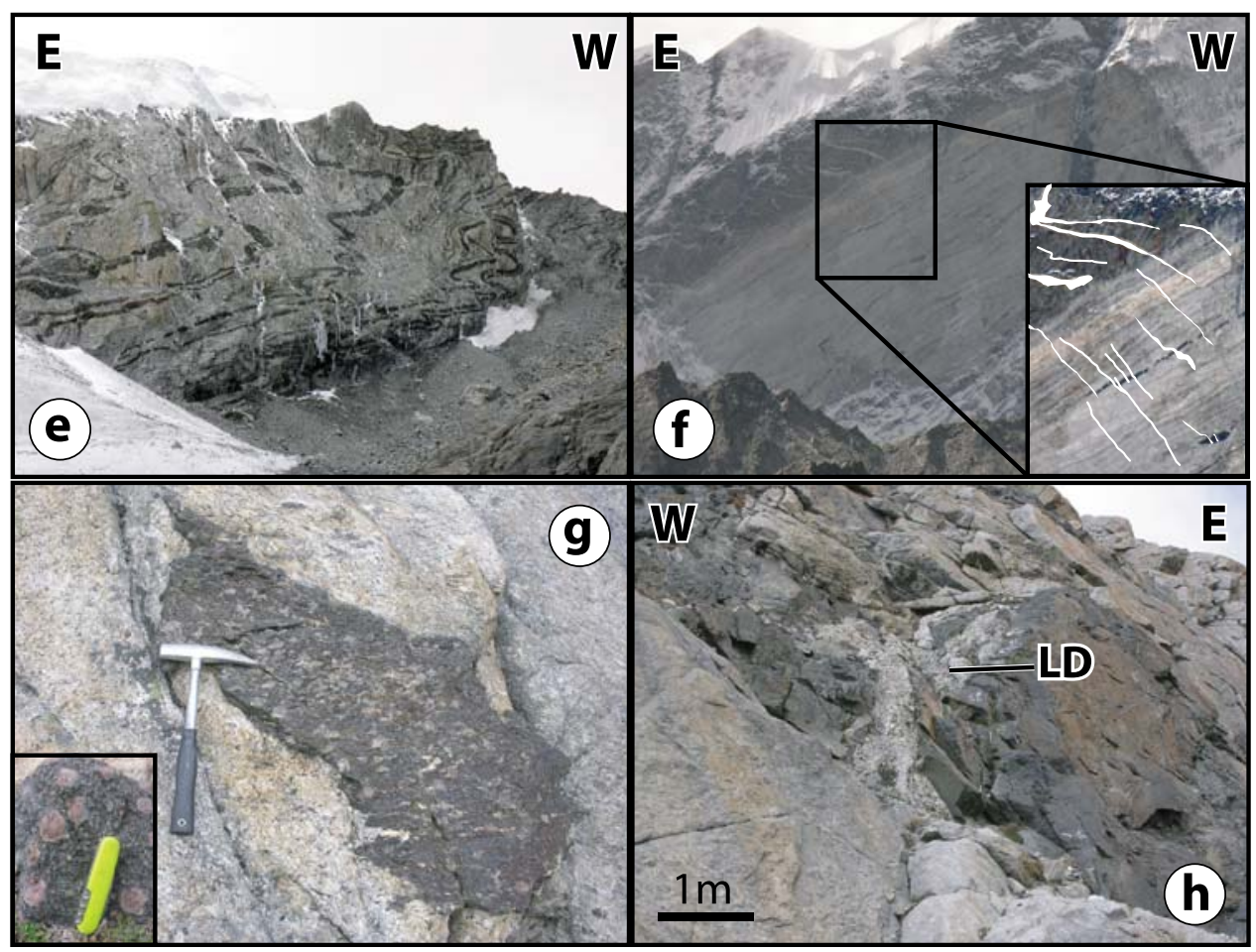

Figure 3. (continued)

\subsubsection{Ama Drime Range}

[23] Except at the very northern tip of the range, above the STD, all rocks comprised between the Kharta-Sangkar and Dinggye active faults are crystalline rocks belonging to the HCS. Along the Belung and Tanghyu valleys most rocks are migmatitic orthogneiss containing large layers and boudins of metabasites that have recorded eclogite facies metamorphism, and that have been attributed to the LHCS (our LoHCS) because of similar rock types [Groppo et al., 2007]. Inherited $\mathrm{U}-\mathrm{Pb}$ zircon and monazite ages from these orthogneisses provide similar 1.7-1.8 Ga age than in the Uleri orthogneisses of the LoHCS [Robinson et al., 2001; Liu et al., 2007; Cottle et al., 2009] confirming the possible correlation. Similar rocks outcrop in the core of the range and south of the Nyonno Ri on the eastern side of the Ama Drime (Figures 2a and 3b). These lithologies constitute the Ama Drime orthogneissic unit (ADO).

[24] Deformed rocks outcropping east of Kharta in the footwall of the Kharta fault have been interpreted by Groppo et al. [2007] as corresponding to the main thrust between the LHCS (LoHCS) and the GHCS (UHCS) (MCTu). In that area, rocks indeed show a strong deformation, with foliations dipping N179 44W on average and lineations striking ESE-WNW to NW-SE (Figures $2 \mathrm{a}$ and 4e). However, analysis of the deformation in rocks that show a clear downdip lineation reveals top-to-the-west shear senses and thus a normal ductile shear zone. That ductile shear zone is in the direct prolongation of the eastern branch of the Kharta active fault (Figure 2a). The relative dispersion of the lineations (Figure 4e) suggests that a pre- vious deformation lineation has been affected by the ductile normal fault. Ductile mylonites with $\sim \mathrm{N}-\mathrm{S}$ foliation and top-to-the-west motion (Figure 31) are observed everywhere in the footwall of the Kharta fault and constitute the Kharta shear zone (Figure 2a). The mylonites trend N15 32W with lineations striking N284 on average in Tanghyu valley (Figure 4f). In the upper Arun gorges the foliations strike N29 27W and the lineations N290 (Figures 2a and 4g).

[25] Similarly, east dipping mylonites have been described on the eastern side of the range in the footwall of the Dinggye fault defining the Dinggye shear zone (Figures 2b, $3 \mathrm{i}, 3 \mathrm{j}$, and 3k) [Zhang and Guo, 2007]. The mylonites trend N178 46E SE of the Nyonno Ri and N21 33E east of the Sangkar Ri, with lineations trending N82 and N103, respectively (Figures $2 \mathrm{a}, 4 \mathrm{k}$, and $4 \mathrm{~m}$ ).

[26] On both sides of the Ama Drime, normal deformation is observed to occur at various temperatures from ductile mylonites to cataclasites with the temperature of deformation decreasing toward the active fault. This pattern is classically interpreted as the progressive uplift of the deep part of the fault in its footwall [e.g., Leloup et al., 1993]. All leucocratic dikes appear to be affected by the normal ductile deformation along the western flank (Figures $2 \mathrm{~b}$ and $3 \mathrm{~m}$ ) while several dikes crosscut the mylonitic foliation along the eastern flank (Figures $2 \mathrm{~b}$ and $3 \mathrm{j}$ ). This could indicate that the western shear zone was active until more recent times than its eastern counterpart.

[27] In the northern part of the Ama Drime range, north of the Nyonno Ri, lithology change to paragneisses and pelitic schists crosscut by leucogranites here defined as the Ama 


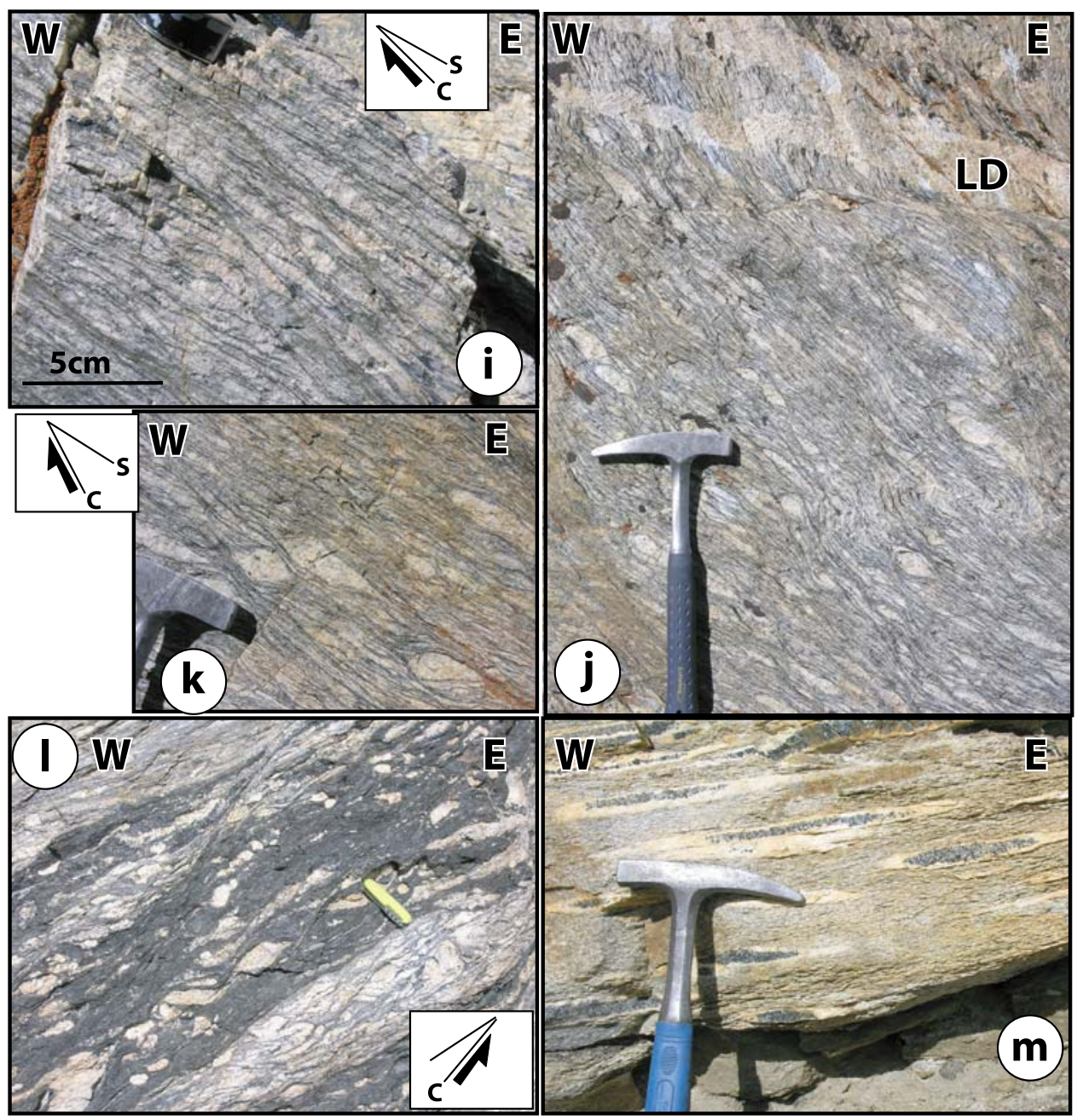

Figure 3. (continued)

Drime paragneissic unit (ADP). The top of this lithologic unit, just bellow the STD is mostly composed of highly sheared pelitic schists and leucogranites similar to those found in the Kharta-Saer unit within the STD SZ. Such rocks are visible dipping to the north below the Sangkar Ri summit (Figure 3d). Paragneiss also outcrop farther south on the eastern flank of the range where they are affected by the Dinggye shear zone (zone k, Figure 2a). Given their structural position, above the ADO attributed to the LoHCS and just below the STD shear zone within the UHCS, such gneisses could be the equivalent of the Kharta gneiss. However, the lack of observation and detailed fieldwork between the Sangkar Ri and the Nyonno Ri leave open other interpretations, as for example a correlation with the LoHCS paragneisses overlying the Uleri Gneiss [Goscombe et al., 2006]. We propose a possible map for the boundary between the Ama Drime paragneissic and orthogneissic units (Figure 2a), although precise mapping and characterization would require further fieldwork. We named this boundary the Nyonno Ri boundary.
[28] There are no precise descriptions of the deformation of the orthogneiss in the core of the Ama Drime. Away from the bounding normal faults, however, the metabasic rocks, when they have not been disrupted in the surrounding migmatites (Figure 3g), define kilometer long layers that are affected by folds with approximately horizontal axial planes and $\sim \mathrm{N}-\mathrm{S}$ trending axis (Figure $3 \mathrm{e}$ ). South of the Nyonno $\mathrm{Ri}$, deformation at the contact between a $\sim 3 \mathrm{~m}$ thick metabasic layer (Figure $3 \mathrm{~h}$ ) and the migmatites is characterized by foliation gently dipping to the east and $\mathrm{N}-\mathrm{S}$ lineations (Figure 4l).

[29] North of the Ama Drime range, quartzites very similar to those outcropping on the active normal fault scarps farther south outcrop $\sim 1 \mathrm{~km}$ north of the Kharta-Sangkar fault (Figure 2a). Foliation in the quartzites trends N24 38W (Figure 4h) parallel to normal faults that affect and tilt the surrounding micaschists and gneiss. When back-tilted the gneiss show a $\sim$ N15 striking lineation parallel to STD shear zone lineations in the area (Figure $4 \mathrm{~h}$ ).

[30] Some authors [e.g., Borghi et al., 2003; Liu et al., 2007] have proposed that the Ama Drime is the northern 
continuation of the Arun anticline described by Bordet [1961]. The Ama Drime is bounded on both sides not only by active normal faults, but also by ductile ones. In that context it appears more as a horst than a fold. Because lowangle ductile normal faults outcrop in the footwall of the steeper active normal faults it is very tempting to interpret these structures as resulting from a single continuous metamorphic core complex type of deformation [e.g., Zhang and Guo, 2007; Jessup et al., 2008; Cottle et al., 2009].

\section{P-T-D-t Path of the Crystalline Rocks of the Ama Drime}

\subsection{P-T Paths}

[31] The petrologic and thermobarometric studies of Lombardo and Rolfo [2000], Liu et al. [2005], Groppo et al. [2007], and Liu et al. [2007] have established that the Ama Drime orthogneissic unit contains the only eclogite found so far in the central Himalayas. These rocks have recorded pressure of at least $1.4 \mathrm{GPa}(\sim 52 \mathrm{~km}$ depth) and have been granulitized at high temperature $\left(\sim 800^{\circ} \mathrm{C}\right)$ during their exhumation (Figure $5 b$ ).

[32] In the following, we present the first petrologic data of the Ama Drime paragneissic unit within the Ama Drime range. Until now such data were restricted to Kharta-Saer unit in the hanging wall of the Kharta fault [Borghi et al., 2003] (Figure 5a) or the Dinggye fault [Leloup et al., 2009, 2010] (Figure 5c). This study is based on the combination of thin section analyses, measurement of mineral chemical composition (punctual and mapping) on a SX100 Cameca CAMEBAX Microprobe at the University of Montpellier operating at $15 \mathrm{kV}$ and $15 \mathrm{nA}$ with a counting time of $10 \mathrm{~s}$ per element, and pseudosection and isopleth calculation using Perple_X software [Connolly, 1990] (detailed procedure available in Text S1, Appendix I) at fixed bulk-rock composition (see Text S1, Appendix I).

4.1.1. P-T Path of the Ama Drime Paragneissic Unit in the Footwall of the Dinggye Active Fault

[33] West of Dinggye, in the footwall of the Dinggye active fault, paragneiss and intruding leucogranites are both affected by top-to-the-east (N103) normal ductile shear (k, Figures $2 \mathrm{a}$ and 4). Sample T5D33 from such paragneisses was collected at an elevation of $5125 \mathrm{~m}$ east of the Sangkar $\mathrm{Ri}$, while T5D39b is a boulder collected from the downstream river fan (Table 1 and Figure 2a). Despite not having sampled in situ, T5D39b was selected because it comes unambiguously from the Sangkar Ri eastern flank and is much fresher than T5D33.
[34] The paragneiss contains biotite, sillimanite, garnet (with biotite, plagioclase, quartz, oxyde and muscovite inclusions), quartz, plagioclase, muscovite, and accessory zircon, apatite and oxides. This paragneiss is locally migmatitic and contains $\mathrm{K}$-feldspar within millimeter-scale unconnected pods. The foliation is defined by biotite, and rare late muscovite while the lineation is outlined by sillimanite. Sample T5D33 is strongly retrogressed and garnet is mostly replaced by chlorite. T5D39b does not show any evidence of such late retrogression and few kyanite relicts have been preserved in the foliation.

[35] Synkinematic biotite, sillimanite and muscovite as well as prekinematic to synkinematic garnets indicate topto-the-east high-temperature ductile normal shearing (Figure 6a).

[36] Four successive paragenesis are recognized in the paragneiss: (P1) biotite + plagioclase + quartz + muscovite as inclusions in large garnets + garnet core; (P2) kyanite or sillimanite + biotite + plagioclase + quartz (including myrmekites) + garnet rim (inclusion-poor zone) $+\mathrm{K}$-feldspar + melt with kyanite predating sillimanite. Note that locally kyanite is included in the garnet rim. This paragenesis is found in the main foliation and in the shear planes (Figure 6a). This implies that a top-to-the-east normal ductile shearing occurred under granulite facies conditions, contemporaneously with partial melting; (P3) biotite + plagioclase + quartz; (P4) The medium- to low-temperature evolution is characterized by replacement of aluminosilicates by muscovite, growth of andalusite replacing kyanite and destabilization of garnet replaced by chlorite, muscovite and chlorobiotite. Continuation of top-to-the-east normal motion during medium temperature evolution is evidenced by the truncation of sillimanite with fractures filled by muscovite and the rare occurrence of synkinematic muscovite in the foliation (Figure 6a). The low-temperature evolution is associated with the garnet fracturation and chloritization.

[37] Biotites (P1 and P3) show high $\mathrm{X}_{\mathrm{Fe}}[(\mathrm{Fe} /(\mathrm{Fe}+\mathrm{Mg})]$ of 0.57 to 0.62 in both samples (Table S2, section 1). In sample T5D39b, the Si(IV) amount in muscovite is significantly higher in garnet inclusions (6.4-6.6 atoms per formula unit (apfu) on the basis of 22 oxygens) than in the matrix (6.1-6.3 apfu) (Table S2, section 2). This suggests that the muscovite in inclusions $(\mathrm{P} 1)$ crystallized at higher pressure than muscovite in the matrix (P4) [Powell and Evans, 1983].

[38] X-ray map and microprobe traverse of T5D39b garnet show complex zoning, with a high-calcium and inclusion-

Figure 4. Structure geometry in the Ama Drime area. Lower hemisphere, equal-area stereonet diagrams. Corresponding areas are located on Figure 2a. All data are listed in Table S1. Foliations and lineations and brittle faults (in gray) are plotted. (a) South Tibetan shear zone of the Dzakar Chu valley. (b) Arun valley below the STDSZ (Kharta-Saer unit). (c) Kharta gneiss immediately north of Kharta. (d) Kharta gneiss SE of Kharta. (e) Arun gorges south of Kharta (Kharta SZ) (here gray corresponds to low-grade deformations). (f) Western part of the Tanghyu valley (Ama Drime orthogneisses, Kharta SZ). (g) SW part of the upper Arun-Phung Chu gorge (Ama Drime orthogneisses, Kharta SZ). (h) Kharta-Saer unit north of the Ama Drime. (i) Foliations in the Ama Drime paragneisses and schistosity (dashed) in the Tethyan Sedimentary Sequence (TSS) NW of the Sangkar Ri. (j) North of Dinggye (Ama Drime paragneisses). (k) SE of the Sangkar Ri (Ama Drime paragneisses, Dinggye SZ). (1) South of the Nyonno Ri (Ama Drime orthogneisses). (m) SE of the Nyonno Ri (Ama Drime orthogneisses, Dinggye SZ). (n) STDSZ south of Dinggye (east of Saer) and S0/S1 and lineation in TSS. 


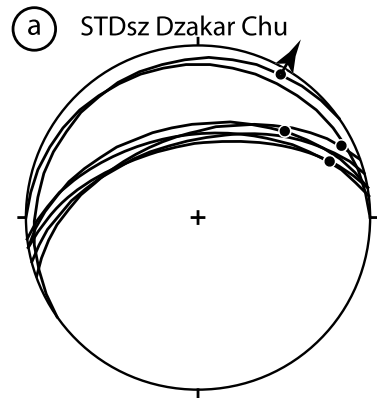

(d) South Kharta

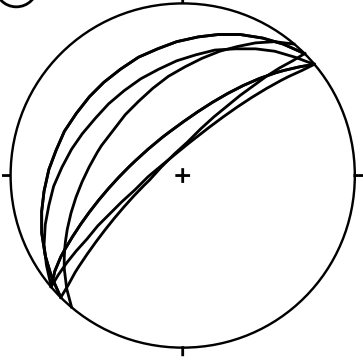

(9) Upper Arun gorges

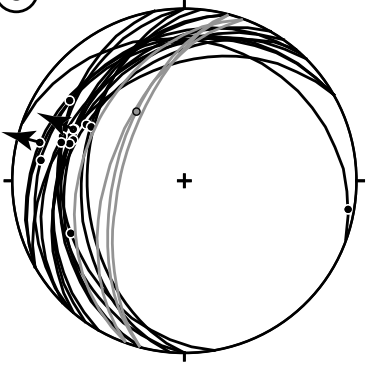

(j) Dinggye

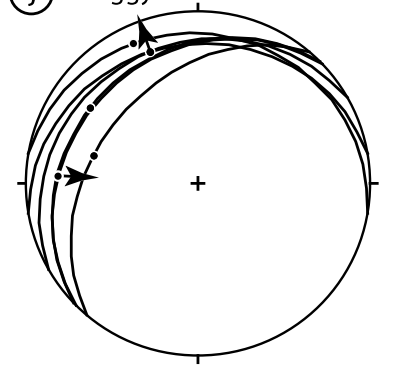

(m) SE Nyonno Ri

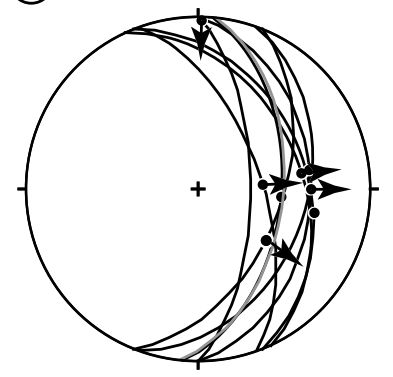

(b) N Kharta basin

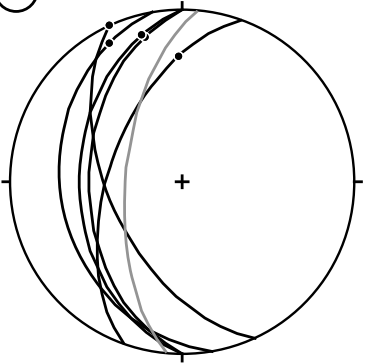

(e) Arun South gorges

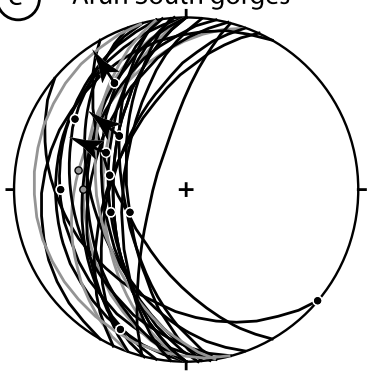

(h) North Flank

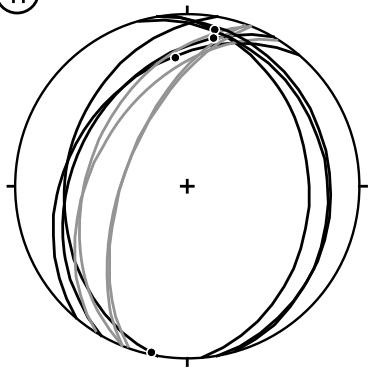

(k) East Sangkar $\mathrm{Ri}$

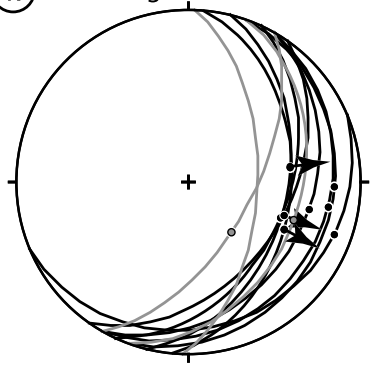

(n) STDsz S Dingyye

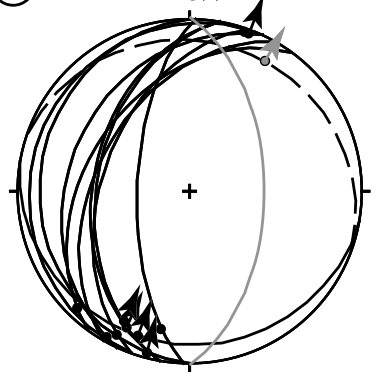

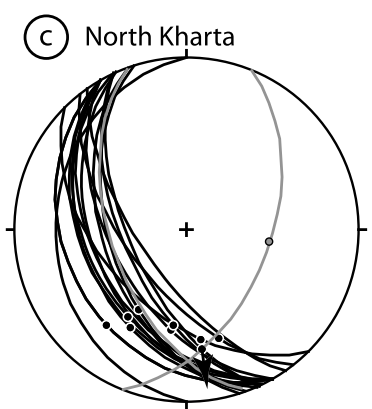

(f) West Tanghyu valley

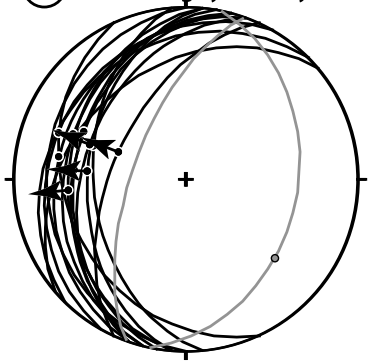

(i) NW Sangkar

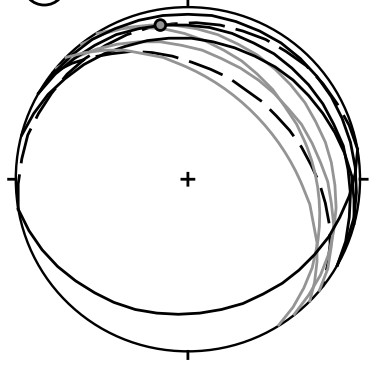

(I) South Nyonno Ri

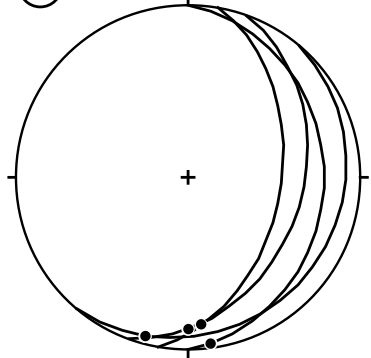

Figure 4

11 of 31 


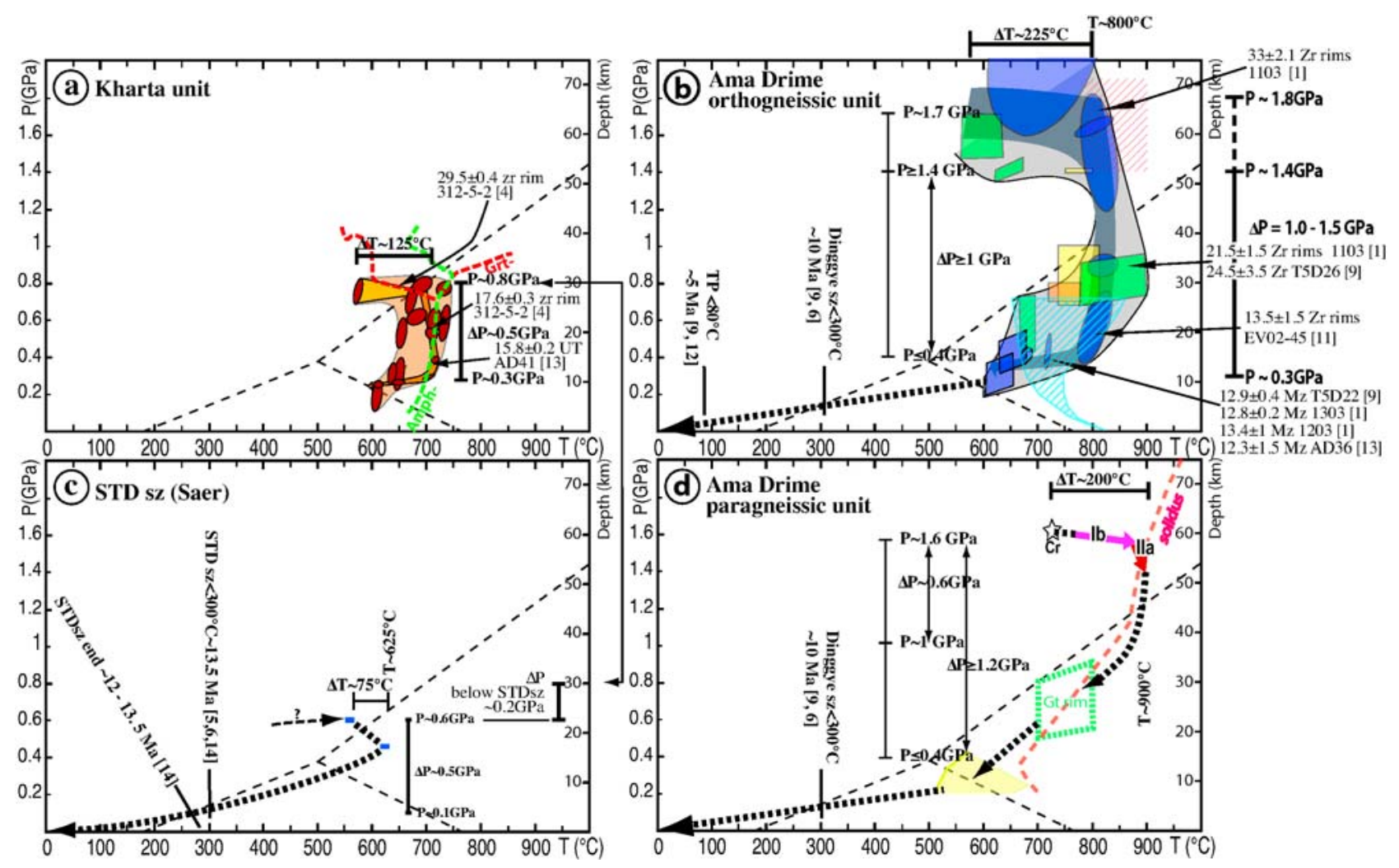

Figure 5. P-T paths and corresponding timing constraints. Aluminosilicates fields are plotted for reference. Samples are located on Figures $2 \mathrm{~b}$ and S1. Numbers without units are ages in Ma. See text for details. (a) Kharta gneiss (Kharta-Saer unit west of the Kharta fault). P-T constraints from Borghi et al. [2003] for samples Ev8, Ev13, Ev16, Ev21, Ev45, Ev70, Ev80, and TB25. Ellipses correspond to individual sample and paragenesis P-T determinations. The narrow dark path corresponds to P-T conditions constrained from isopleths. The lighter path connects the largest documented pressure (M2, sample Ev45) with the earliest paragenesis (M1, sample Ev45). The stability fields of amphibole and garnet are drawn for metabasite chemistry [Groppo et al., 2007] in order to discuss the ages of zircons overgrowths within sample 312-5-2. Age constraints from Li et al. [2003] [4] (sample 312-5-2) and Cottle et al. [2009] [13] (sample AD41). (b) Ama Drime orthogneisses. P-T data from Liu et al. [2005] (green, samples T01-T386 and T01-T389); Liu et al. [2007] [1] (yellow, samples 1103 and 1303); Groppo et al. [2007] (blue, samples Ev02-Ev42 and Ev45, Ev97-Ev60), and Cottle et al. [2009] [13] (orange, sample AD43). All samples are amphibolite boudins unless the ones dark framed that correspond to embedding gneiss. Range of initial vapor-absent melting by mica breakdown between 1.4 and 1.8 GPa (red hatching) compiled from Vielzeuf and Holloway [1988], Vielzeuf and Clemens [1992], Vielzeuf and Montel [1994], PatiñoDouce and Beard [1996], Castro et al. [2000], Harris et al. [2004], Auzanneau et al. [2006], and Indares et al. [2008]. Range of monazite crystallization below $0.7 \mathrm{GPa}$ (blue hatching) from Kelsey et al. [2008]. Timing constraints from Liu et al. [2007] [1] (samples 1103 and 1303), Rolfo et al. [2005] [11] (Ev0245), Cottle et al. [2009] [13] and this study [9] (sample T5D22). (c) STD shear zone near Saer. P-T constraints from Leloup et al. [2010] [14]. The $\sim 300^{\circ} \mathrm{C}$ timing constraint comes from micas argon dating [Leloup et al., 2009, 2010] [14]; Hodges et al. [1994] [5]; Zhang and Guo [2007] [6]). (d) Ama Drime paragneisses. P-T constraints from this study [9] (T5D33 and T5D39b, see Figure 6). The $\sim 300^{\circ} \mathrm{C}$ timing constraint comes from micas argon dating (this study [9] and Zhang and Guo [2007] [6]).

rich core (garnet I, P1) and a late, low-calcium, inclusionpoor rim (garnet II, P2) (Table S2, section 3, and Figures 6b and $6 c)$.

[39] In more detail, garnet I (P1) can be separated into two zones. The innermost zone (Ia, Figure 6c) is rich in muscovite and plagioclase inclusions, and does not present clear composition zoning (Alm 0.662-0.685, Pyr 0.180-0.192, Gros 0.104-0.124, Spes 0.031-0.034) (Table S2, section 3, and Figure 6c). Detailed analysis of zone Ia X-ray map shows that grossular and pyrope contents decrease and almandine content increases concentrically around the inclusions (Figure 6b). Such pattern suggests that chemical 


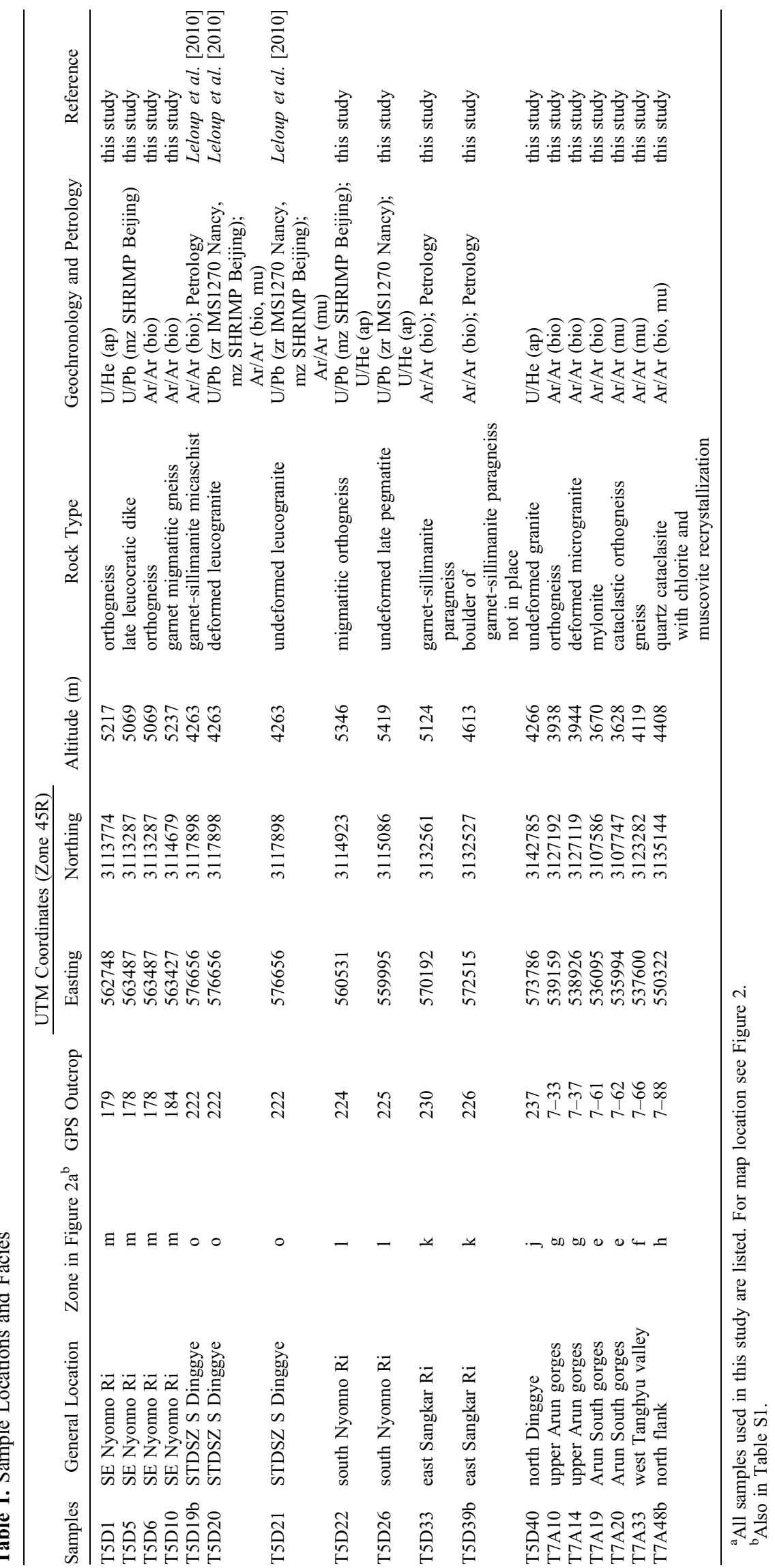



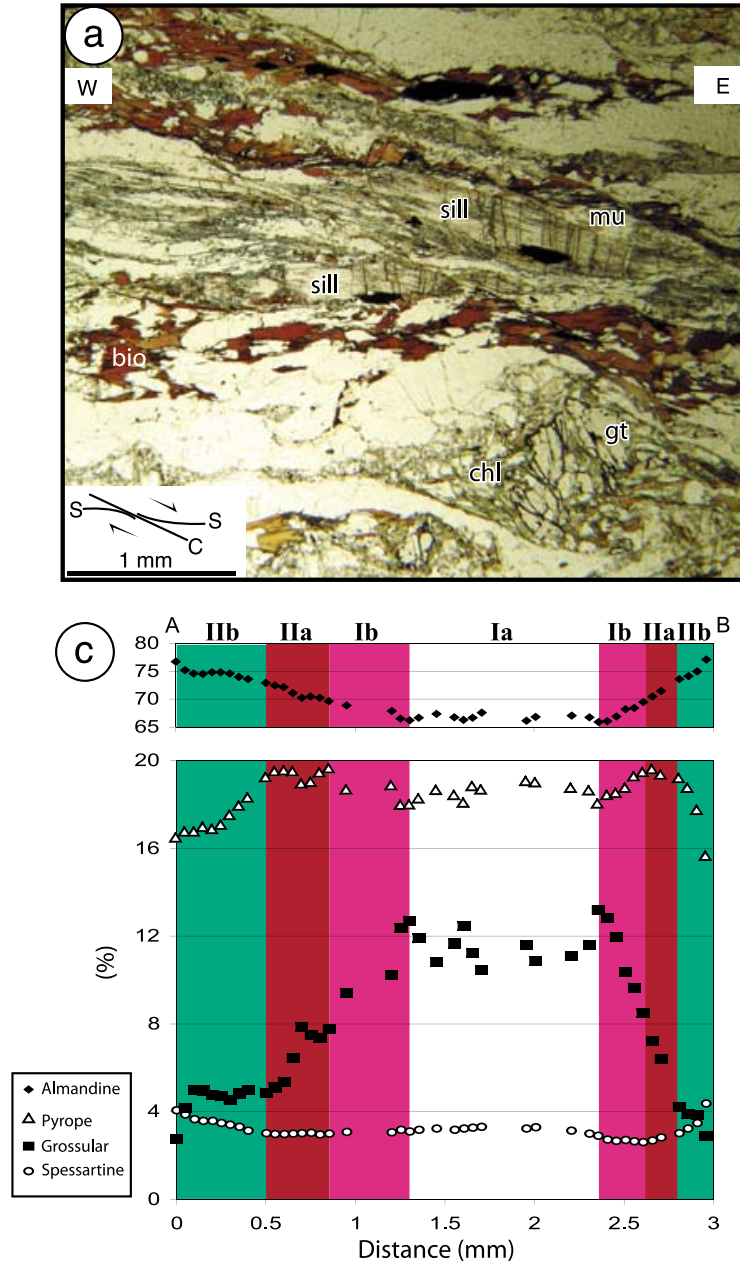
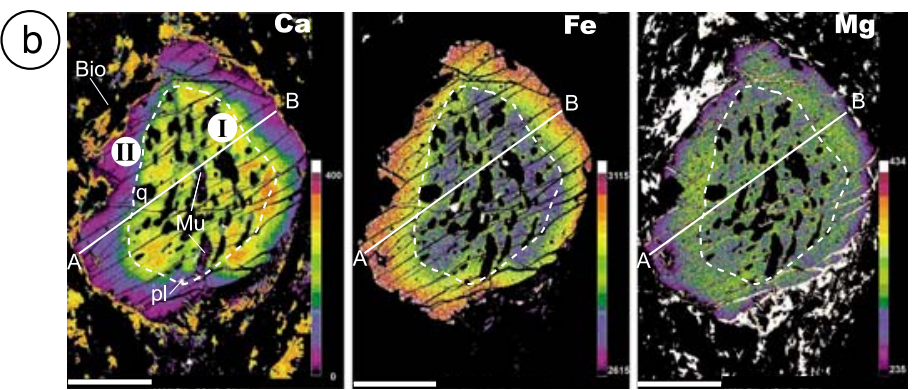

\section{(d)}

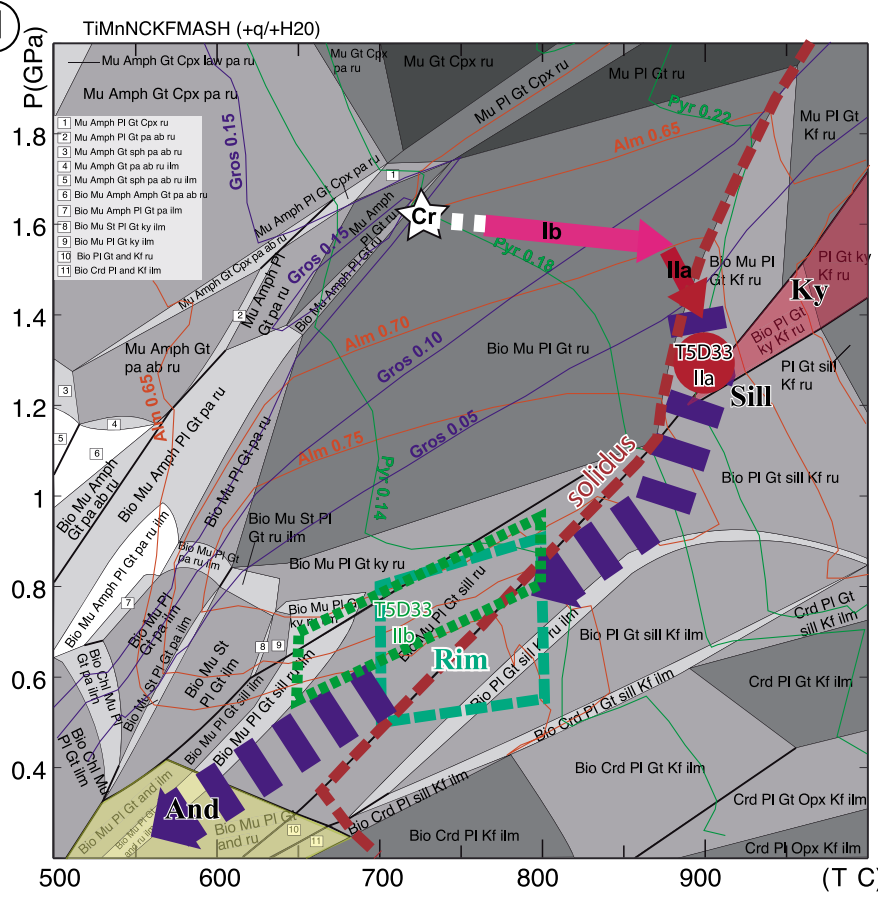

Figure 6. P-T path of the Ama Drime paragneisses in the footwall of the Dinggye normal fault. (a) T5D33 thin section picture microphoto showing synsillimanite-bearing top-to-the-east shear planes. Optical microscope, section parallel to lineation and perpendicular to foliation. (b) X-ray maps showing $\mathrm{Ca}, \mathrm{Fe}$, and $\mathrm{Mg}$ compositional zoning of garnets in sample T5D39b. (c) Garnet composition along the profile (white line) shown in Figure 6b. (d) $\mathrm{H}_{2} \mathrm{O}$ saturated NCKFMASMnTi pseudosection for garnet-biotite-sillimanite micaschist T5D39b (Perple_X2007) for the corresponding whole-rock composition. White, light gray, medium gray, and dark gray fields are divariant, trivariant, quadrivariant, and quintivariant fields, respectively. Mineral abbreviations follow Holland and Powell [1998]. Red, green, and blue lines are almandine, pyrope, and grossular isopleths, respectively. T5D39b P-T path is constrained by the white star ( $\mathrm{Cr}$, garnet core), pink and red arrows and the green long-dashed box (garnet outer rim). Constraints on T5D33 P-T path are plotted for comparison. In Figures 6b, 6c, and $6 \mathrm{~d}$, I and II indicate garnet core (paragenesis 1) and rim (paragenesis 2), respectively.

diffusion occurred around the inclusions after their incorporation, modifying garnet composition. Garnet initial chemistry is only preserved away from the inclusions, and is not present along the Figure $6 \mathrm{c}$ transect. It is characterized by relatively high grossular content (0.124), low almandine and pyrope contents (0.662 and 0.180 , respectively) and intermediate spessartine content (0.032) (Table S2, section 3). Zone $\mathrm{Ib}$ is characterized by pyrope and almandine increase from 0.66 and 0.18 to 0.70 and 0.20 , respectively, by grossular content decrease from 0.13 to 0.08 (Table S2, section 3, and Figure 2c) and almost constant spessartine content $(\sim 0.03)$.

[40] Within garnet rims (zone II, P2), which contain few biotite, quartz, kyanite, and plagioclase inclusions, two zones can be distinguished (Figure 6c). Zone IIa shows continuous grossular decrease from 0.08 to 0.05 and almandine increase from 0.70 to 0.73 but constant pyrope and spessartine $(\sim 0.19$ and $\sim 0.03$, respectively) (Table S2, section 3, and Figure 6c). In zone IIb, grossular is constant $(0.05)$ as almandine and spessartine slightly increase $(0.73$ 
to 0.75 and 0.04 to 0.03 , respectively) and pyrope decrease from 0.19 to 0.17 . Outermost rim is characterized by high almandine (up to 0.79$)$ and spessartine $(>0.05)$ and relatively low grossular and pyrope content $(0.03$ and 0.13 , respectively) (Table S2, section 3, and Figure 6c).

[41] In sample T5D33 no garnet with muscovite and plagioclase inclusions (P1, garnet zone I) were observed. Only small porphyroclasts are still visible with zone II compositions (P2).

[42] In sample T5D39b, plagioclases have higher $\mathrm{Ca}$ content when included within or in contact with garnet (An 0.25-0.46) than in the matrix (An 0.29-0.24) (Table S2, section 4). In sample T5D33 the Ca content of the matrix plagioclase are even higher (An 0.40-0.43) probably because T5D33 is highly retrogressed as evidenced by the replacement of garnet by chlorite. K-feldspar (P2) are similar in both samples (Or 0.88-0.89).

[43] T5D39b P-T path was obtained using pseudosections, calculations of garnet isopleths and classical thermobarometry (Figure 6d). Despite some evidences for partial melting, constant chemistry is assumed as melts are only restricted to small unconnected pods at the microscopic scale, and because there are no evidences for local melt escape nor intrusion on macroscopic samples or outcrops.

[44] The garnet chemical zoning presented above yields to the interpretation that high temperatures following paragenesis 1 have induced chemical reequilibration of plagioclase and biotite inclusions with the surrounding garnet in garnet cores. Garnet composition corresponding to initial garnet growth has thus to be found in garnet cores but away from inclusions, while early plagioclase composition would be preserved in the matrix away from garnets. These compositions correspond to high-pressure $(\sim 1.6 \mathrm{GPa})$ and temperature around $775^{\circ} \mathrm{C}$ (star $\mathrm{Cr}$ on Figure 6d). Garnet compositions and evolution in zone Ib (pyrope and almandine increase and grossular decrease) reflect P-T conditions during the garnet core growth. They correspond to heating up to $\sim 850^{\circ} \mathrm{C}$, at almost constant pressure $(\sim 1.6 \mathrm{GPa})$ (Ib arrow on Figure 6d). Inner part of zone II (IIa, P2) is compatible with late high-temperature growth or reequilibration at $\sim 875^{\circ} \mathrm{C}$ during decompression from 1.6 to $1.4 \mathrm{GPa}$ (IIc arrow on Figure 6d). This high-temperature event induced the reequilibration in garnet cores around biotite and plagioclase inclusions. Based on Figure $6 \mathrm{~d}$ pseudosection, presence of kyanite during the $\mathrm{P} 2$ implies that $\mathrm{T}$ was still at least at $875^{\circ} \mathrm{C}$ when decompression reached $1.2 \mathrm{GPa}$ (Ky zone on Figure 6d). The outer part of zone II most likely corresponds with late diffusion at garnet rim. This late reequilibration was constrained coupling garnet-biotite thermometry and garnet-sillimanite-plagioclase barometry from the GTP compilation [Reche and Martinez, 1996] for mineral in close contact (plagioclase, biotite, and garnet rim). Only calibration based on $\mathrm{Fe}, \mathrm{Mg}, \mathrm{Ca}, \mathrm{Mn}$, and $\mathrm{Ti}$ exchange were used. Results indicate that this late diffusion occurred at 700 $800^{\circ} \mathrm{C}$ and $0.9-0.5 \mathrm{GPa}$ (green dashed box on Figure $6 \mathrm{~d}$ ).

[45] These latter P-T estimates, compared with the ones obtained for garnet zone IIa, imply that an important decompression event took place from $\sim 1.6 \mathrm{GPa}$ to $\sim 0.7 \pm$ $0.2 \mathrm{GPa}$ and during a small decrease of temperature from $\sim 875$ to $750 \pm 50^{\circ} \mathrm{C}$. This episode was associated with partial melting by muscovite breakdown and successive growth of kyanite and sillimanite (P2, Figure 6d). The late retrograde evolution is only constrained by the presence of andalusite and the absence of cordierite suggesting pressures comprised between 0.4 and $0.2 \mathrm{GPa}$ and temperature lower than $675^{\circ} \mathrm{C}$ (yellow area on Figure 6d).

[46] T5D33 provides similar P-T evolution, but starting at 1.3 $\mathrm{GPa}$ and $900^{\circ} \mathrm{C}$ (Figure 6d) based on pseudosection since only $\mathrm{P} 2$ garnets have been preserved. Late diffusion at T5D33 garnet rim is constrained to occur at $0.75 \pm 0.2 \mathrm{GPa}$ and $725 \pm 75^{\circ} \mathrm{C}$ (Figure 6d) based on garnet-biotite thermometry and garnet-sillimanite-plagioclase barometry. The retrograde evolution yielded to the crystallization of $\mathrm{Ca}$-rich plagioclases in T5D33.

4.1.2. P-T Path of the Ama Drime Orthogneissic Unit: Comparison With the Paragneissic Unit

[47] Lombardo and Rolfo [2000] were the first to suggest that the rocks now outcropping in the heart of the Ama Drime, here referred as the Ama Drime orthogneissic unit, were among the deepest in the Himalayan belt. Since then, the P-T path of the Ama Drime unit, has been documented by the studies of Liu et al. [2005], Groppo et al. [2007], Liu et al. [2007], and Cottle et al. [2009]. These studies appear to document a common P-T path (Figure $5 \mathrm{~b}$ ). The path starts with an isobaric heating $\left(\Delta \mathrm{T} \sim 225^{\circ} \mathrm{C}\right)$ at pressures above $1.4 \mathrm{GPa}$, most probably between 1.6 and $1.8 \mathrm{GPa}$, prior to reach conditions compatible with partial melting at $\sim 800^{\circ} \mathrm{C}$ of metapelitic and metagranitic rocks. This is followed by a large nearly adiabatic decompression $(\Delta \mathrm{P}=1.0$ to $1.5 \mathrm{GPa}$ corresponding to 37 to $56 \mathrm{~km}$ ) at $\sim 800^{\circ} \mathrm{C}$, ending around $0.3 \mathrm{GPa}(\sim 11 \mathrm{~km}$ depth). From this point, cooling starts and the path entered the field were vapor-absent melting for metapelite and metagranite may initiate (Figure 5b). The end of the P-T path is still poorly constrained.

[48] Such P-T path is broadly similar to the one obtained in the overlying Ama Drime paragneissic unit (see section 4.1.1), but with a peak temperature $\sim 100^{\circ} \mathrm{C}$ cooler (Figure $5 \mathrm{~d}$ ). From these data the Ama Drime paragneissic unit could simply correspond to the metamorphosed sedimentary cover of the Ama Drime orthogneissic unit, the two units being exhumed together. However, the two units can also be separated by a tectonic contact along the postulated Nyonno Ri boundary, which finite offset would be small.

\subsection{Geochronology}

\subsection{1. $\mathrm{U}-\mathrm{Th} / \mathrm{Pb}$}

[49] T5D22 is a sample from the migmatitic gneisses, which constitute most of the Ama Drime orthogneissic unit, sampled south of the Nyonno $\mathrm{Ri}$ in the footwall of the Dinggye normal fault (Figure 2b).

[50] Monazites selected for SHRIMP dating are fairly big (100 $\mu \mathrm{m}$ in average) and well crystallized. In thin section, they are observed as inclusion within micas and quartz. No significant relationship appears between the age and the spot locations (Table S4, section 2). T5D22 monazite ages show scatter, with ${ }^{208} \mathrm{~Pb} /{ }^{232} \mathrm{Th}$ ages ranging from 11.6 to $14.4 \mathrm{Ma}$, for an average at $12.85 \pm 0.39 \mathrm{Ma}(\mathrm{n}=15, \mathrm{MSWD}=3.3)$ (Figure 7a). On a Tera-Wasserburg isochron most data concentrate just above the Concordia (Figure $7 \mathrm{~b}$ ). If one excludes the youngest and the three oldest data points, 
regression forced through present-day common lead and the 11 remaining data, gives an age of $13.54 \pm 0.14 \mathrm{Ma}$ (MSWD 1.9) (Figure 7b). Keeping all points would not change the age $(13.59 \pm 0.27 \mathrm{Ma})$ but would significantly alter the MSWD (10.8). The TW regression age is $1 \mathrm{Ma}$ older than the ${ }^{208} \mathrm{~Pb} /{ }^{232} \mathrm{Th}$ average one. In the absence of any clue for lead overcorrection, the average age is preferred.

[51] As monazite is easily dissolved into the melt during partial melting and appears during final melt crystallization [Kelsey et al., 2008], the $12.9 \mathrm{Ma}$ age most likely represent final melt crystallization.

[52] This age of $\sim 12.9 \mathrm{Ma}$ is close to other monazite ages found in the Ama Drime orthogneisses west of the range: $12.8 \pm 0.2$ (sample 1303 [Liu et al., 2007]), $13.4 \pm 1 \mathrm{Ma}$ (sample 1203 [Liu et al., 2007]), and 12.3 $\pm 1.5 \mathrm{Ma}$ (sample AD36 [Cottle et al., 2009]), confirming crystallization of the Ama Drime migmatites at that time (Figure 9). In such rocks, however, zircon rims yield older Cenozoic ages of $33 \pm 2.1$ and $22.9 \pm 2.1 \mathrm{Ma}$ in sample 1103 , and between 30 and $23 \mathrm{Ma}$ in sample 1303 [Liu et al., 2007] that could correspond to previous magmatic evolution (Figure 9).

[53] T5D5 is a small ( $\sim 10 \mathrm{~cm}$ wide) leucocratic dike crosscutting the ductile foliation in the footwall of the Dinggye fault in the Ama Drime orthogneissic unit (Figures $3 \mathrm{j}$ and $2 \mathrm{~b}$ ). Monazites are well crystallized and fairly big (100 $\mu \mathrm{m}$ in average). In thin section, they are observed as inclusion within micas and quartz. Some grains were systematically avoided for dating because CL images revealed they were patchy, or had zircon inclusions. Corrected ${ }^{208} \mathrm{~Pb} /{ }^{232} \mathrm{Th}$ ages range from 10.4 to $13.9 \mathrm{Ma}$ (Table S4, section 1, and Figure 7a). The average of the whole population is $12.52 \pm 0.54 \mathrm{Ma}$ with a fairly large MSWD at 6 . A cumulative probability plot exhibits two maxima at $\sim 11$ and $\sim 13$ Ma suggesting two age populations (Figure $7 \mathrm{c}$ ). Average ${ }^{208} \mathrm{~Pb} /{ }^{232} \mathrm{Th}$ ages of the two subpopulations are $13.09 \pm 0.32 \mathrm{Ma}(\mathrm{MSWD}=1.5)$ and $10.98 \pm 0.39 \mathrm{Ma}(\mathrm{MSWD}=1.13)$, respectively (Figure 7a and Table S4, section 1). When plotted in a Tera-Wasserburg diagram, the data display again two statistically different populations, whose ages do not overlap within uncertainties. Regressions forced though present-day common lead give intercepts at $13.96 \pm 0.27 \mathrm{Ma}(13$ points, MSWD = 1.9) and $12.54 \pm 0.47 \mathrm{Ma}(5$ points, MSWD = 1.5) for these two populations (Figure 7d and Table S4, section 1).

[54] We interpret these results as indicating a long period of monazite crystallization with final dike emplacement at the time of the youngest monazite crystallization: $10.98 \pm$ $0.39 \mathrm{Ma}$. This suggests that down to the east ductile normal faulting was over, at least locally, at $\sim 11 \mathrm{Ma}$. Note that the oldest monazite population in T5D5 is very similar to the monazites from T5D22 (Figure 9) and thus probably corresponds to inheritance from this main crystallization event.

[55] T5D26 is a pegmatite dike that cuts across an amphibolite-rich layer (Figure $3 \mathrm{~h}$ ) of the Ama Drime orthogneissic unit $\sim 4 \mathrm{~km}$ west of the Dinggye active fault (Figure 2). The dike is restricted to the basic layer and does not appear to cut the migmatites. However, observation of similar dikes in the high cliff north of the Ama Drime summit reveals that the dikes cut across all facies of the Ama Drime orthogneissic unit even if they are locally restricted to the basic layers probably because of rheology contrasts (Figure 3f).

[56] The sample yielded clear elongated zircons with well develop facets and no zoning. In thin section, they are observed as inclusion within micas and quartz. All the analyzed points are concordant but show a wide range in age from 7 to $27 \mathrm{Ma}$ (Figure 7e and Table S3), thus yielding the youngest concordant ages from this study. The distribution of ${ }^{206} \mathrm{~Pb} /{ }^{238} \mathrm{U}$ ages, which suffer the least from ${ }^{204} \mathrm{~Pb}$ correction shows 9 ages out of 12 ages younger than $12 \mathrm{Ma}$. The average of these ages $(9.8 \pm 1.2 \mathrm{Ma}, \mathrm{MSWD}=126)$ is interpreted as the best estimate for the pegmatite crystallization. The few older ages, between 21 and $27 \mathrm{Ma}$, suggest zircons inherited from the surrounding Ama Drime orthogneissic unit (Figure 9). One cannot exclude, however, that the data correspond to a discordia chord between $\sim 7$ and $\sim 27 \mathrm{Ma}$. In that case the crystallization age of T5D26 would be $7.3 \pm 0.2 \mathrm{Ma}$.

[57] The $9.8 \pm 1.2 \mathrm{Ma}$ age is close to the crystallization age of T5D5 (10.98 $\pm 0.39 \mathrm{Ma}$, see above) that seems to belong to the same dike generation from field observation (Figure 2b). On the western side of the range, six monazites of a leucocratic dike crosscutting a large amphibolite boudin (A.D. 35, Figure S1) yield an age of $11.6 \pm 0.4 \mathrm{Ma}$ [Cottle et al., 2009] very close to the final crystallization age we propose for T5D26 and T5D5.

\subsubsection{Argon Results}

[58] Argon results are summarized in Table 3, and all data are listed in Table S5.

\subsubsection{Dinggye Shear Zone}

[59] New argon ages from the Ama Drime paragneissic unit in the footwall of the Dinggye normal fault were obtained from T5D33 and T5D39. Biotites from paragneiss T5D33 show a saddle shaped age spectra with minimum ages at circa 11.8 Ma (Figure 8a), suggesting excess, which is correctly resolved by the inverse isochron approach yielding an age of $10.8 \pm 0.4 \mathrm{Ma}$ (MSWD = 7.1) (Figure 8b). Biotites from sample T5D39 also display a rugged age spectra, with a minimum age close to $11.5 \mathrm{Ma}$ (Figure S2g). Excess argon is not completely resolved on the inverse isochron, which age of $13.1 \pm 0.8 \mathrm{Ma}$ is probably a maximum (Figure S2h). That range of biotite ages in the paragneisses compares well with that obtained by Zhang and Guo [2007] on similar facies, ranging from 10.2 to 13.2 Ma.

[60] Within the Ama Drime orthogneissic unit, sample T5D6 corresponds to an orthogneiss showing down to the east ductile normal faulting and crosscut by T5D5 leucogranite (Figure 3j). Biotites yield a saddle age spectra with a pseudoplateau at $10.8 \pm 0.1 \mathrm{Ma}$ and an inverse isochron age of $10.7 \pm 0.3 \mathrm{Ma}$ (Figures $8 \mathrm{a}$ and $8 \mathrm{~b}$ ). Cooling of T5D6 below $\sim 300^{\circ} \mathrm{C}$ thus happened immediately after the emplacement of T5D5. In the same unit, T5D10 biotites show a strong excess argon effect (Figure S2g). The inverse isochron is tied up close to the ${ }^{36} \mathrm{Ar} /{ }^{40} \mathrm{Ar}$ axis and points to an old age of $18.6 \pm 1.2 \mathrm{Ma}$, which must be regarded with great care (Figure S2h).

[61] Six muscovite and biotite ${ }^{39} \mathrm{Ar} /{ }^{40} \mathrm{Ar}$ ages from the footwall of the Dinggye fault were published by Zhang and Guo [2007] (samples T01-17, T01-24, T01-25, T01-26, 

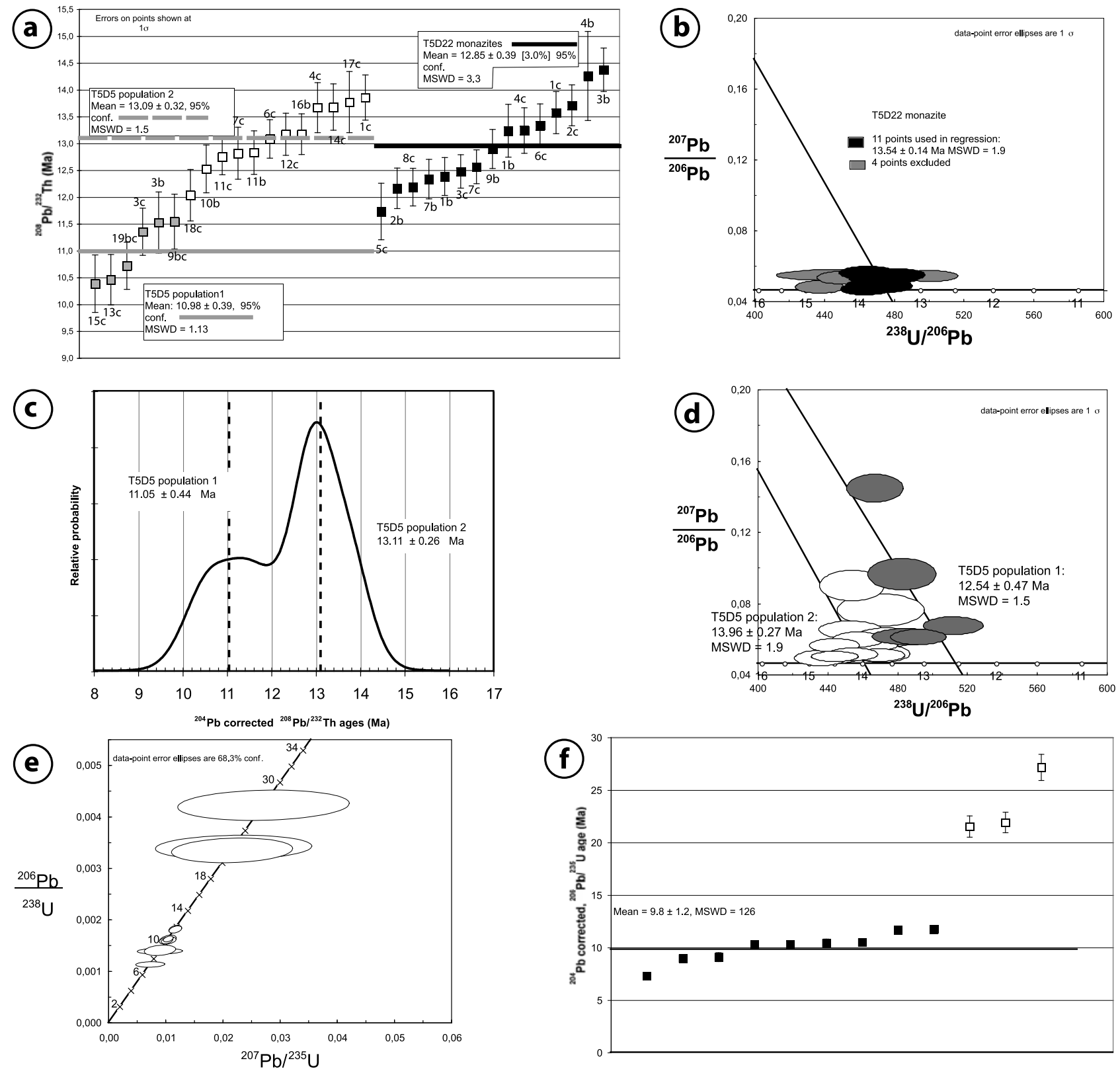

Figure 7. U- $\mathrm{Th} / \mathrm{Pb}$ data. Corresponding data are listed in Tables $\mathrm{S} 3$ and $\mathrm{S} 4$. (a) Averages of ${ }^{208} \mathrm{~Pb} /{ }^{232} \mathrm{Th}$ monazite ages corrected for common lead via 204Pb for T5D5 (2 populations) and T5D22. Spot numbers are indicated. (b) T5D22 monazite Tera-Wasserburg diagram, with regression forced through presentday common lead. (c) Cumulative probability plot of T5D5 monazite ${ }^{208} \mathrm{~Pb} /{ }^{232} \mathrm{Th}$ ages from which isoplot software [Ludwig, 2003] extracts two subpopulations. (d) T5D5 monazites Tera-Wasserburg diagram, with regressions forced through present-day common lead (two populations are distinguished). (e) Concordia diagram for zircons from pegmatite dike (T5D26). All points are concordant but show a wide age range. (f) T5D26 zircon ${ }^{206} \mathrm{~Pb} /{ }^{238} \mathrm{U}$ corrected for common lead via ${ }^{204} \mathrm{~Pb}$ ages. A crude average (with a high MSWD) is calculated excluding the three oldest points.

T01-29, T01-33, Figure S1). All these ages are comprised between 13.34 and 10.2 Ma, which together with our data yield an overall age range between 18.5 and $10.2 \mathrm{Ma}$ (Figure 9). Excluding only one outlier (T5D10 biotite that happens to be the less reliable) out of the eleven available data restrains the age range to $13.7-10.2 \mathrm{Ma}$ and yield average ages of $10.72 \pm 0.73 \mathrm{Ma}$ for the biotites and $12.1 \pm$ 2.4 Ma for the muscovites (Figure 9). Muscovites and biotites have nearly the same age suggesting a very rapid cooling at medium temperatures. This event is $\sim 2$ Myr younger than the 

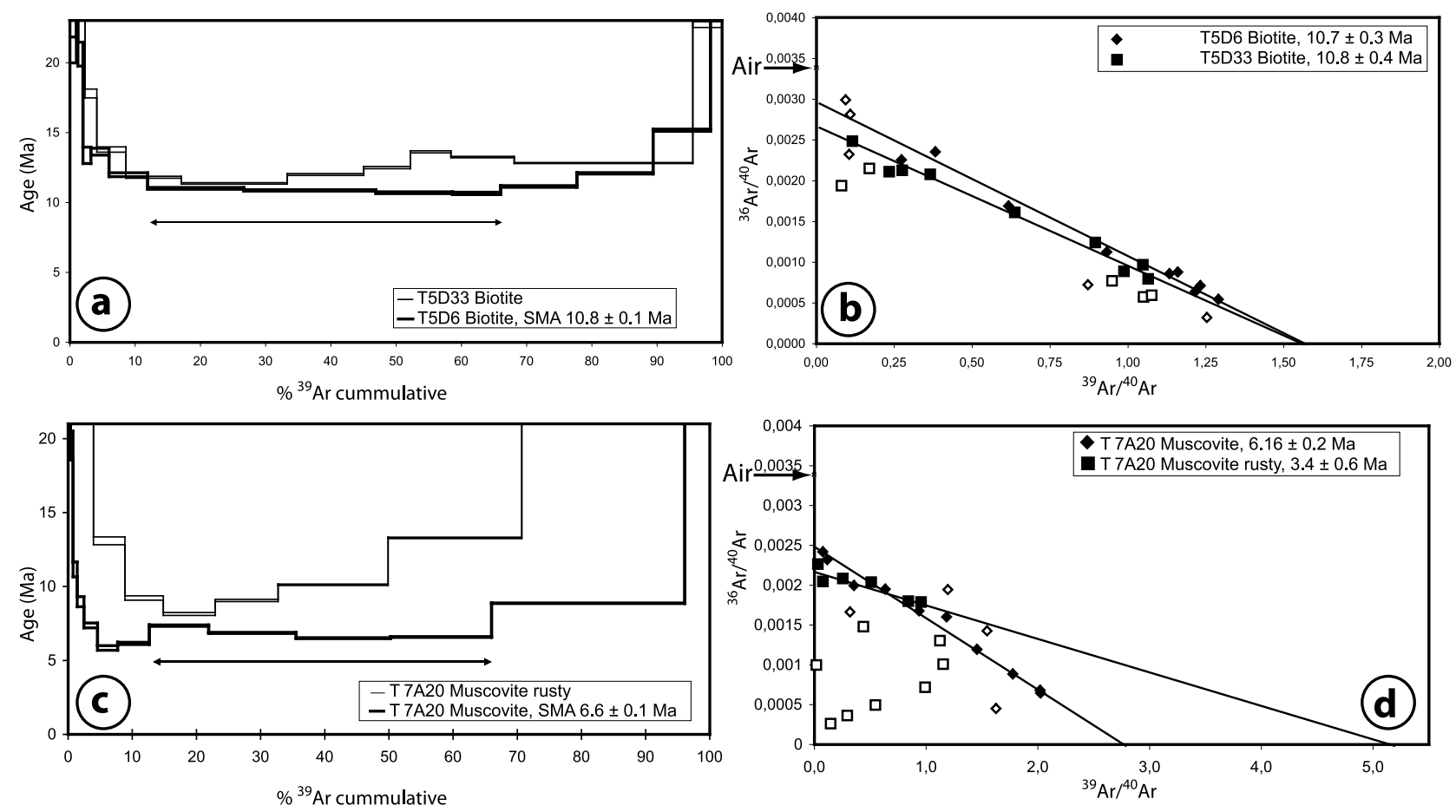

Figure 8. Examples of argon data from the Ama Drime range. Other data are plotted in Figure S2. All data are summarized in Table 3 and listed in Table S5. For inverse isochron plots, empty symbols where not used in the regression calculation. (a) T5D33 and T5D6 biotites age spectra. (b) T5D33 and T5D6 biotites inverse isochron plot. (c) T7A20 muscovites age spectra. Note that two populations (normal and rusty) have been distinguished. (d) T7A20 muscovites inverse isochron plot.

rapid cooling event observed in the STDSZ [Leloup et al., $2009,2010]$ and corresponds to the final age of crystallization of T5D5 (crosscutting dike).

\subsubsection{Kharta Shear Zone}

[62] On the western side of the Ama Drime range micas ${ }^{39} \mathrm{Ar} /{ }^{40} \mathrm{Ar}$ ages in the Kharta shear zone appear even younger than on the eastern flank.

[63] T7A19 biotites yield the oldest ages with a saddle age spectra, a pseudo plateau at $24.1 \pm 0.3 \mathrm{Ma}$ and an isochron age of $23.5 \pm 0.5$ (Figures S2a and S2b). T7A33 biotites show the same kind of age spectra with a $10.9 \pm 0.2 \mathrm{Ma}$ plateau and a isochron age of $10.1 \pm 0.9 \mathrm{Ma}$ (Figures S2a and S2b). The pseudo plateau age of T7A10 biotites is $8.5 \pm 0.2 \mathrm{Ma}$ and the isochron age is $8.5 \pm 0.3 \mathrm{Ma}$ (Figures S2c and S2d). T7A14 biotites show minimum ages around $10 \mathrm{Ma}$ and an ill-defined isochrone age of $6.2 \pm$ $0.8 \mathrm{Ma}$ (Figures S2c and S2d). All these biotites come from the ductile part of the Kharta normal fault, which deformation temperature encompasses the biotite closure temperature $\left(300 \pm 40^{\circ} \mathrm{C}\right)$. This suggests that the Kharta SZ was active in the time interval 10-6 Ma, while T7A19 was probably not reset from a previous thermal event (Figure 9). Indeed, T7A19 is a meta-arenite in which biotite, plagioclase, garnet and quartz detrital grains have only been partly recrystallized during shearing and chlorite-grade metasomatism within the Kharta SZ. We thus suggest that T7A19 biotites cooled below $\sim 300^{\circ} \mathrm{C}$ at $\sim 25$ Ma were eroded and deposited in a small basin later affected by the Kharta SZ.

[64] T7A20 sampled within the Kharta SZ less than $200 \mathrm{~m}$ away from T7A19 (Figure 2a) contains two generations of muscovite: big $(\sim 0.2 \mathrm{~mm})$ porphyroclasts and smaller minerals aligned within the foliation and shear zones. Two populations of muscovite have also been distinguished during the separation process on their clear or rusty appearance. The two populations have been dated separately. The clear one shows a pseudoplateau at $6.6 \pm 0.1 \mathrm{Ma}$ and an inverse isochron at $6.2 \pm 0.2 \mathrm{Ma}$ (Figures $8 \mathrm{c}$ and $8 \mathrm{~d}$ ), while the rusty one is associated with a saddle age spectrum and an ill-defined isochron age of $3.4 \pm 0.6 \mathrm{Ma}$ (Figures $8 \mathrm{c}$ and $8 \mathrm{~d}$ ).

[65] T7A48 comes from the north part of the Ama Drime range in the hanging wall of the fault linking the Kharta and Sangkar active faults (Figure 2a). There, cataclastic quartzites outline NNW trending normal faults (see section 3.2.3). The sample yielded two generations of muscovite: clear porphyroclasts within the foliation of the cataclasite, and rusty muscovites that, together with chlorobiotite, fill vertical late fractures. The porphyroclasts yield ages close to those of most muscovites from the Dinggye SZ [Zhang and Guo, 2007] (Figure 9), with a saddle pseudoplateau at $11.7 \pm 0.2 \mathrm{Ma}$ and an inverse isochrone at $12.2 \pm 0.2 \mathrm{Ma}$ (Figures S2e and S2f). The second muscovite generation gives a saddle age spectrum without any plateau and an illdefined isochron age of 3.3 $\pm 0.8 \mathrm{Ma}$ (Figures S2e and S2f). 


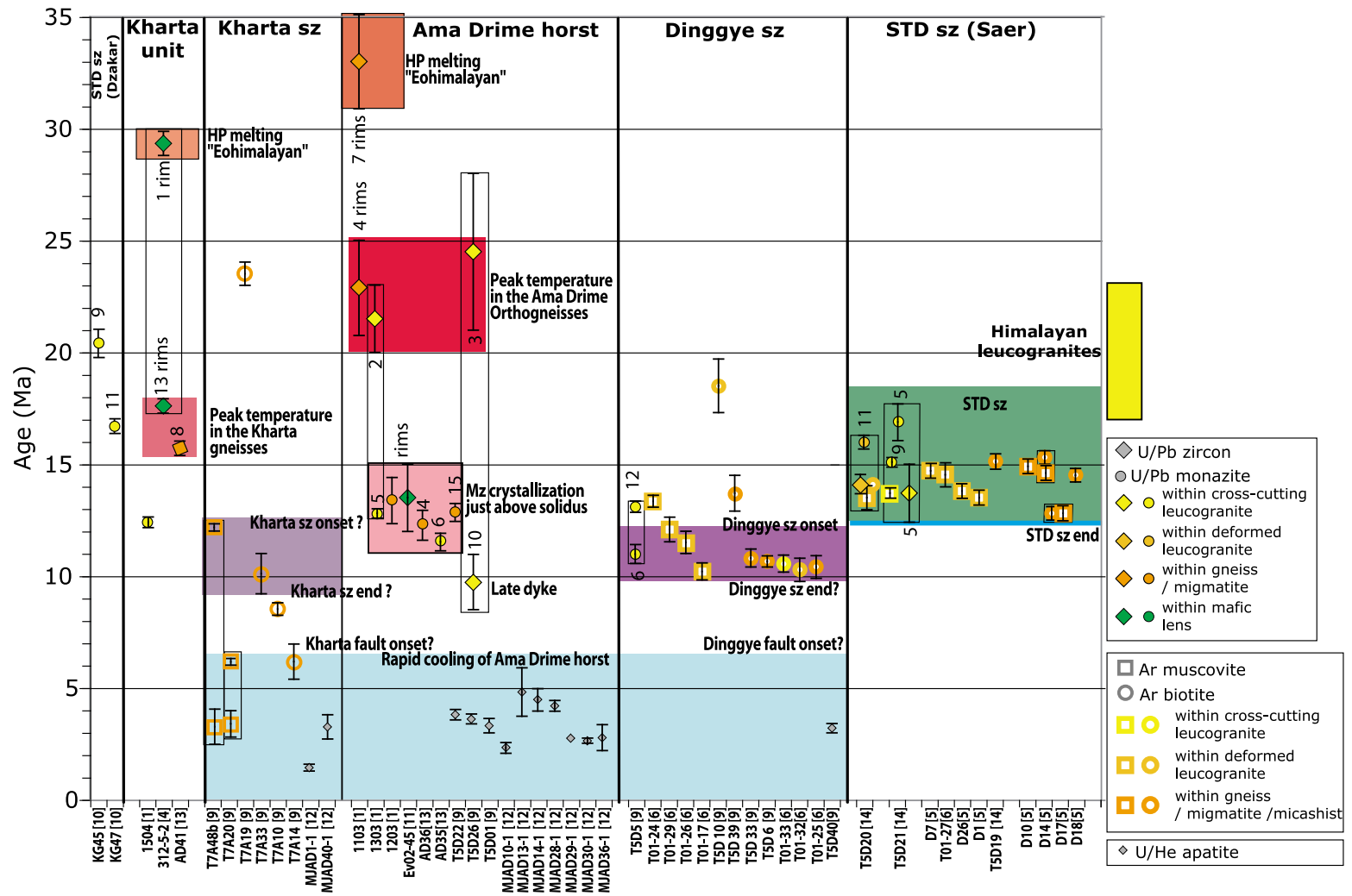

Figure 9. Geochronologic ages synthesis. Geochronologic ages of Ama Drime area from bibliography and this study. Samples are labeled at the bottom of the graph and organized by tectonometamorphic units presented from west to east. Symbols correspond to mineral and techniques, and colors relate to rock types. References are [1] Liu et al. [2007]; [4] Li et al. [2003]; [5] Hodges et al. [1994]; [6] Zhang and Guo [2007]; [9] this study; [10] Cottle et al. [2007]; [11] Rolfo et al. [2005]; [12] Jessup et al. [2008]; [13] Cottle et al. [2009]; and [14] Leloup et al. [2009, 2010]. The age range of Higher Himalayan leucogranites is plotted for comparison [Harrison et al., 1998]. Main tectonometamorphic events are outlined by color boxes.

\subsubsection{Apatite U-Th/He Results}

[66] In order to constrain the timing of the latest stages of exhumation of the Ama Drime massif in the footwall of the Dinggye normal fault, apatite (U-Th)/He dating was performed on three samples from the valley south of the Nyonno Ri (T5D01, 22 and 26) spanning in elevation between 5217 and $5419 \mathrm{~m}$, and one sample collected east of the Sangkar Ri at $4270 \mathrm{~m}$ (T5D40) (Figure 2a). Samples are orthogneiss (T5D01), migmatite (T5D22) and granites (T5D26 and T5D40). Apatites have been analyzed at the Caltech Noble Gas Laboratory following the procedure of House et al. [2000]. As the samples were relatively poor in good quality apatite (i.e., inclusion free) we ran single grains and 1 (T5D01), 2 (T5D40) or 4 replicates (T5D22 and T5D26). The $1 \sigma$ error on age is taken as the standard deviation of the replicate analyses divided by $(n-1)^{1 / 2}$, where $n$ is the number of replicate analyses performed. Samples with multiple replicates gave good reproducibility, with a $1 \sigma$ error lower than $10 \%$ of the mean age. For the sample with only one replicate $(\mathrm{T} 5 \mathrm{D} 01)$ we use a conservative $1 \sigma$ error corresponding to $10 \%$ of the age.

[67] All ages range between 3.2 and $3.8 \mathrm{Ma}$ (average $3.4 \pm$ $0.4 \mathrm{Ma}$ ) (Table S6 and Figure 9). Altogether ages appear to correlate with elevation giving an apparent exhumation rate of $2.9 \mathrm{~km} / \mathrm{Myr}$ (Figure 10). However, this correlation rests on only four points, and the single point at an altitude significantly lower than the 3 others is located $\sim 35 \mathrm{~km}$ farther to the north (T5D40, Figure 2a). Other apatite (U-Th)/He ages have been obtained by Jessup et al. [2008] for samples (1) close to samples T5D01, 22, and 26, (2) from the western side of the Ama Drime massif next to the Kharta normal fault, and (3) in the core of the massif. All these samples are located between $28^{\circ} 4^{\prime} \mathrm{N}$ and $28^{\circ} 15^{\prime} \mathrm{N}$ (Figure S1). Altogether most of Jessup et al. [2008] apatite (U-Th)/He ages and our data for samples T5D01, 22 and 26 correlate with elevation (Figure 10) defining and apparent elevation rate of $\sim 1 \mathrm{~mm} / \mathrm{yr}$ for ages comprised between 1.4 and 4.2 Ma. The two samples (MJAD13 and MJAD14) from Jessup et al. [2008] with errors superior to $10 \%$ of the mean age, have been excluded from the age-elevation relationship as for these samples age replicates correlate negatively with grain size, which suggest He implantation, but that can also be related with zoning or presence of U-rich inclusions. Another sample (MJAD40) is significantly older than expected from the age-elevation relationship (Figure 10). This sample is located in the Kharta shear zone and was 


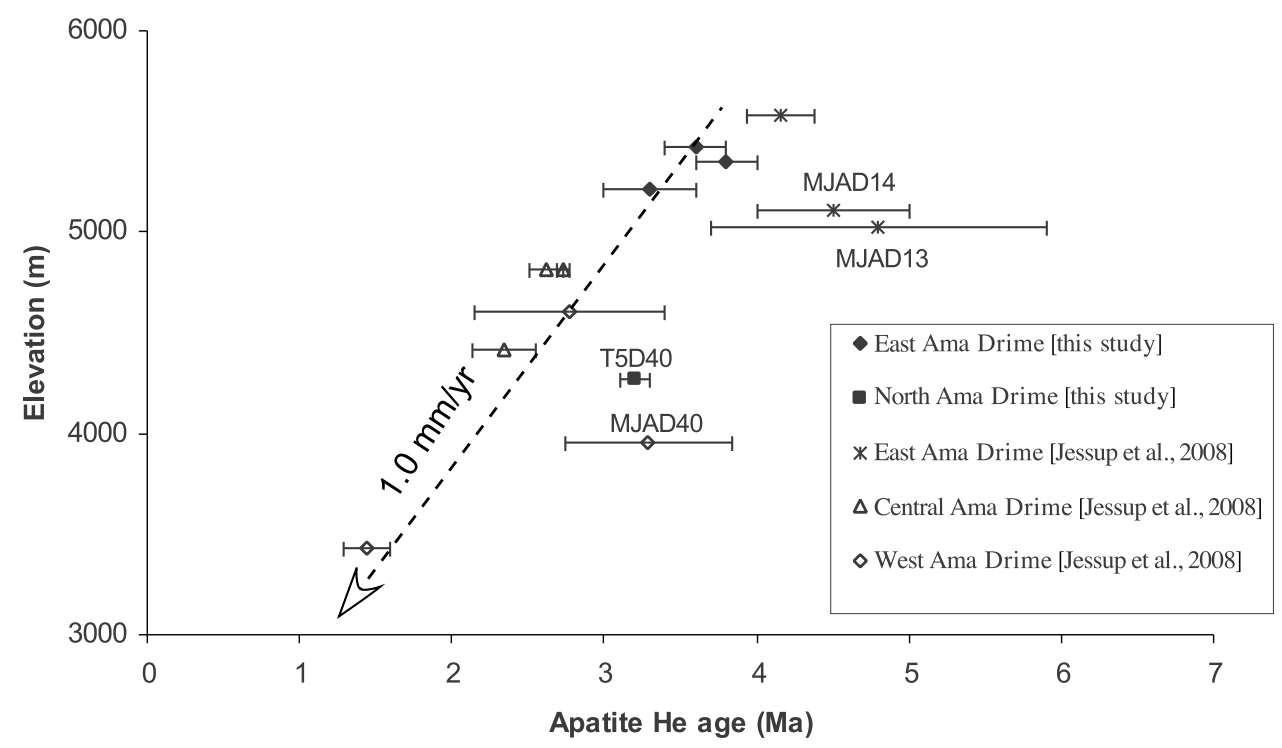

Figure 10. Plot of Ama Drime (U-Th)/He apatite ages versus elevation. Data from this study (Table S6) and Jessup et al. [2008]. This plot suggests that the Ama Drime range was vertically exhumed as a single block since at least $4 \mathrm{Ma}$ with a rate of about $1 \mathrm{~mm} / \mathrm{yr}$. See text for details.

then most probably less exhumed than the sample located in the range outside of the deformation zones explaining the relatively old measured age.

[68] The age-elevation relationship obtained (Figure 10) suggests that the part of the Ama Drime massif covered by Jessup et al. [2008] and our sampling (i.e., the central part between the Nyonno Ri and the Ama Drime peaks) was exhumed as a single block with no tilting between the Dinggye and the Kharta normal faults since at least 4.2 Ma. This implies that in this area, and since 4.2 Ma, the slip rate is the same on both normal faults. The relatively old age obtained for sample T5D40, located about $35 \mathrm{~km}$ north of the other samples could indicate a lower amount of exhumation toward the northern Ama Drime, where the normal faults terminate. This is coherent with the decrease of the crest elevation $(\sim 6000 \mathrm{~m}$ in the central part and $\sim 5500$ in the northernmost part), together with the decrease of the height of the triangular facets $(700-800 \mathrm{~m}$ in the central part and 400-500 in the northernmost part), both suggesting a decrease of the throw and/or rate of the active faults toward the north.

\section{Discussion: Structural Evolution of the Ama Drime Area}

[69] In the central and eastern Himalayan range, amphibolitic and granulitic rocks recording peak pressure between 1.2 and 1.0 GPa have been observed close to the MCTl [Guillot, 1999; Kohn et al., 2001; Harris et al., 2004]. Farther north, in the HCS, between the MCTl and the STD shear zone peak pressure is usually comprised between 0.7 and 1.0 GPa [Vance and Mahar, 1998; Searle et al., 1999; Vannay et al., 1999; Goscombe and Hand, 2000; Borghi et al., 2003; Dasgupta et al., 2004; Kohn et al., 2004]. So far pressures higher than 1.4 GPa are only found in the Ama Drime range.

[70] P-T-t path reconstructions of the amphibolitic and granulitic events of the HCS evidence that two main tectonometamorphic events occurred all across the Himalaya. One Eo-himalayan event, between 50 and $30 \mathrm{Ma}$, probably associated to burial and subsequent thermal reequilibration (see Hodges [2000] and Kohn et al. [2005] for reviews) and one HT event at 25-20 Ma related to leucogranite formation [Simpson et al., 2000]. P-T path reconstruction, away from the STD shear zone, indicates that this HT event is generally coeval to a slight $\mathrm{T}$ increase $\left(50-100^{\circ} \mathrm{C}\right)$ and a strong decompression [Guillot, 1999; Searle et al., 1999; Goscombe and Hand, 2000; Harris et al., 2004]. This HT event is generally considered as contemporaneous with thrusting along the MCT1 [Hodges et al., 1996; Catlos et al., 2004].

[71] We discuss below if, and how, the Ama Drime area rocks conform with, or depart from this general pattern, and what constraints their P-T-D-t path brings on orogenic models.

\subsection{P-T-t Path of Ama Drime Rocks During the Himalayan Orogeny}

[72] Comparison of the P-T paths of the various units and compilation of more than 60 radiochronologic data (Figure 9 and Tables 2 and 3), allow us to propose a coherent scenario for the timing and duration of the metamorphism and exhumation phases of the Ama Drime rocks during the Himalayan orogeny.

[73] $\mathrm{U}-\mathrm{Th} / \mathrm{Pb}$ zircon and monazite dating of the Ama Drime orthogneissic unit, in orthogneisses, paragneisses, metabasites as well as undeformed leucocratic dikes and granites, yield Cambrian to Precambrian inherited ages as well as numerous Cenozoic ages between 33 and $10 \mathrm{Ma}$ 


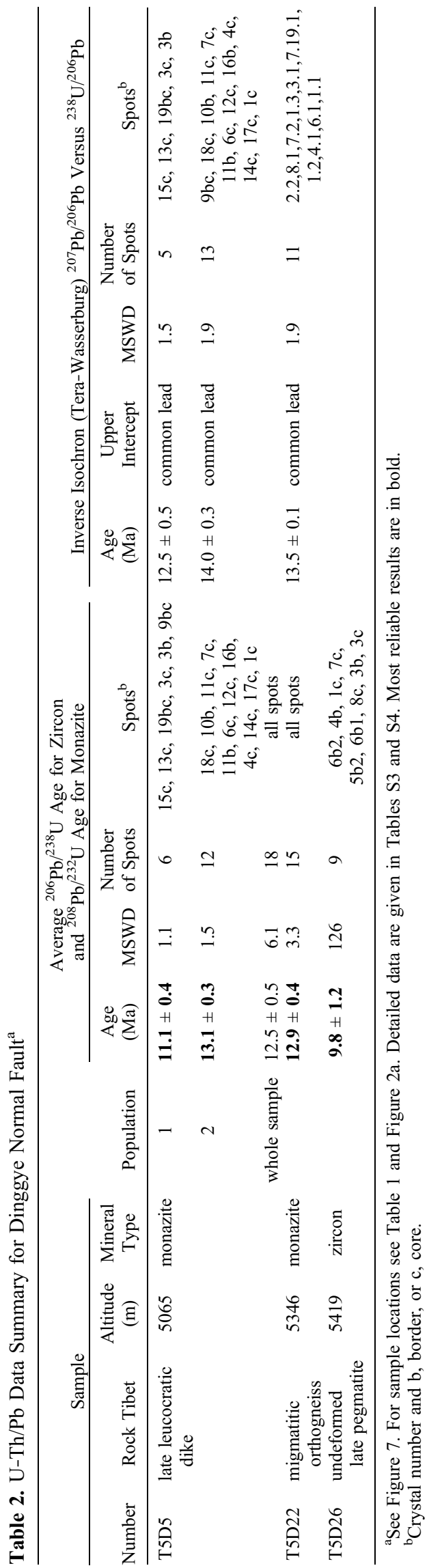

(Figure 9). The Cambrian ages are characteristic of Himalayan Crystalline Series [Richards et al., 2005, and reference therein].

[74] The Cenozoic ages indicate that the high-temperature and high-pressure, metamorphic event is Oligo-Miocene and relates to the Himalaya building, not to a previous metamorphic episode. However, the detailed interpretation of these ages is not always straightforward. The spread in age results from the variety of minerals and facies dated as well as from mechanisms inducing several age populations of a given mineral in a given sample.

[75] Published $\mathrm{U} / \mathrm{Pb}$ ages of the Ama Drime migmatitic paragneisses in the Ama Drime orthogneissic unit reveal two populations of metamorphic zircon at $33 \pm 2 \mathrm{Ma}$ and $23 \pm$ $2 \mathrm{Ma}$ (sample 1103 [Liu et al., 2007]) (Figure 9). In such amphibolitic to granulitic facies rocks metamorphic zircon are only formed during anatexis [Schiotte et al., 1989; Vavra et al., 1999]. In this environment overgrowth mostly occurs during two phases (1) subsolidus growth at the onset of partial melting and (2) at peak temperature and during subsequent cooling [Roberts and Finger, 1997; Schaltegger et al., 1999; Vavra et al., 1999; Rubatto et al., 2001; Kelsey et al., 2008]. In metapelitic system partial melting temperature is dependant of the bulk composition. Based on granite chemistry and our pseudosection, partial melting is related with vapor-absent melting by mica breakdown [Visonà and Lombardo, 2002]. Combining data from experimental petrology at $\sim 1.4-1.8 \mathrm{GPa}$ [Vielzeuf and Holloway, 1988; Vielzeuf and Clemens, 1992; Vielzeuf and Montel, 1994; Patiño-Douce and Beard, 1996; Castro et al., 2000; Auzanneau et al., 2006] as well as pseudosection calculation [Harris et al., 2004; Indares et al., 2008], pelites, granites and graywackes partial melting initiate between $800^{\circ} \mathrm{C}$ and $900^{\circ} \mathrm{C}$. We propose that the $33 \pm 2 \mathrm{Ma}$ age corresponds to the onset of partial melting most probably occurring during the isobaric temperature increase, and the $23 \pm 2 \mathrm{Ma}$ age to the peak $\mathrm{T}$ and start of the subsequent cooling $(1.0-0.5 \mathrm{GPa}$ and $\sim 800-850^{\circ} \mathrm{C}$ (Figure $5 \mathrm{~b}$ ). We note that zircons of similar ages have been found in undeformed granites and leucogranitic dikes of the Ama Drime (samples 1033 of Liu et al. [2007] and T5D26 of this study; Figure 9) where they are probably inherited from this high-temperature event.

[76] Monazites ages obtained from similar migmatitic gneisses are all comprised between 13 and $12 \mathrm{Ma}$ [Liu et al., 2007; Cottle et al., 2009; this study] (Figure 9). As monazite is easily dissolved during partial melting, inherited or prograde grains are usually not preserved, and $\mathrm{U}-\mathrm{Th} / \mathrm{Pb}$ ages most likely correspond to cooling close to the solidus [Kelsey et al., 2008]. Based on a detailed study on various bulk rock compositions in the NCKFMASH system, monazite crystallization occurs between 650 and $850^{\circ} \mathrm{C}$ for pressure below $0.7 \mathrm{GPa}$ [Kelsey et al., 2008].

[77] We propose that the $12-13 \mathrm{Ma}$ monazite ages correspond to $\mathrm{P}-\mathrm{T}$ conditions of $0.3-0.4 \mathrm{GPa}$ and $650-750^{\circ} \mathrm{C}$ occurring during the cooling event following the adiabatic decompression (Figure 5b).

[78] Within metabasic rocks of the same Ama Drime orthogneissic unit, Rolfo et al. [2005] obtained 12-15 Ma U/ $\mathrm{Pb}$ ages on metamorphic zircons. In such rocks zircon 


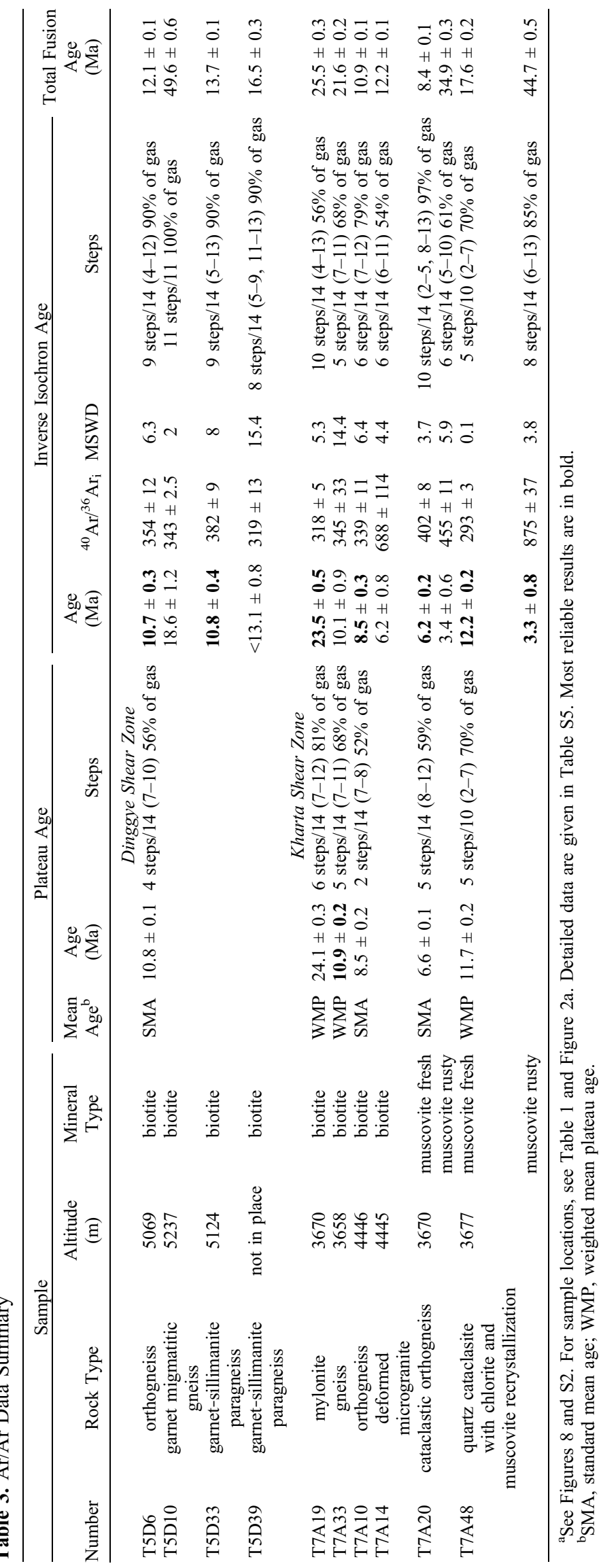


growth is rather related with garnet and/or hornblende breakdown than anatexis [Fraser et al., 1997]. Thus, coupling these ages with their petrogenetic grid, Groppo et al. [2007] proposed that $12-15$ Ma zircon growth most probably occurred at $0.7-0.4 \mathrm{GPa}$ and $750-840^{\circ} \mathrm{C}$ near the end of the nearly adiabatic decompression event. Such timing matches well our interpretation of the monazites and zircons ages in the migmatitic orthogneiss (Figure 5b).

\subsection{P-T-t Paths of the Kharta-Saer Unit}

[79] East of the Ama Drime, the $15.09 \pm 0.11 \mathrm{Ma} \mathrm{U}-\mathrm{Th} / \mathrm{Pb}$ age of a crosscutting granite (T5D21) suggest that deformation stopped in the STDSZ at $\sim 15$ Ma east of Saer [Leloup et al., 2009, 2010] (Figure 9). Muscovite and biotite argon ages further suggest rapid cooling between 15 and $13.5 \mathrm{Ma}$ and that temperature dropped below $\sim 300^{\circ} \mathrm{C}$ at $\sim 13.5 \mathrm{Ma}$ (Figures 5 and 9). Brittle motion could have carry on along the STD after that date. However, the STD is offset by the Dinggye shear zone, which was active before $\sim 11 \mathrm{Ma}$, because T5D5 dike dated at $11 \pm 0.4 \mathrm{Ma}$ (Figures 7a and 7c and Table 2) crosscuts the foliation. Motion on the STDS thus stopped between $\sim 13.5$ and $11 \mathrm{Ma}$ [Leloup et al., 2009, 2010]. Together with the P-T path, this indicates that rocks now outcropping in the STDSZ near Saer were at less than $0.1 \mathrm{GPa}$ pressure ( $\sim \mathrm{km}$ depth) at the end of motion along the STDS (Figure $5 \mathrm{c}$ ).

[80] West of the Ama Drime within the Kharta gneiss, $\mathrm{U} / \mathrm{Pb}$ zircon ages from a granulitic metabasite are mostly around $17.6 \pm 0.3 \mathrm{Ma}$ with two outliers at $29.5 \pm 0.4 \mathrm{Ma}$ and $1991 \pm 26 \mathrm{Ma}$ (sample 312-5-2 [Li et al., 2003]). If the last age is clearly inherited from the protolith, the Cenozoic ages provide constraints on the timing of Himalayan metamorphism. As previously discussed, in metabasic rocks, zircon most likely forms following garnet and/or amphibole breakdown [Fraser et al., 1997]. Breakdown of garnet into orthopyroxene + plagioclase has been clearly identified in the sample dated by Li et al. [2003], but in the absence of chemical data the position of the garnet and amphibole reactions in the $\mathrm{P}-\mathrm{T}$ space cannot be precisely reconstructed. Bearing in mind that the rock bulk composition strongly influences the position of these reactions, first-order estimates can be obtained by combining the petrogenetic grid of Groppo et al. [2007] with the P-T path of the Kharta-Saer unit proposed by Borghi et al. [2003]. Zircon formation may have occurred (1) by amphibole breakdown during either isobaric heating or adiabatic decompression, and/or (2) by garnet breakdown during early decompression (Figure 5a). We thus suggest that the $29.5 \pm 0.4$ Ma zircon rim developed during the isobaric heating (Figure 5a), while the $17.6 \pm$ $0.3 \mathrm{Ma}$ zircon formed during the adiabatic decompression (Figure 5a). Uranothorites within the melanosome of a migmatitic orthogneiss attributed to the Kartha gneisses and affected by deformation in the Kharta SZ (AD41, Figure S1), yield a concordant $\mathrm{U}-\mathrm{Pb}$ age of $15.8 \pm 0.2 \mathrm{Ma}$ (Figure 9) [Cottle et al., 2009]. Cottle et al. [2009] interpret this age as the timing of partial melting. Based on partial melting curve for $\mathrm{P}<1 \mathrm{GPa}$ for metapelitic, metagranite and metagreywacke (see Patiño-Douce and Harris [1998] for a review), such event may occur above $700^{\circ} \mathrm{C}$. Altogether, these data are compatible with high-temperature conditions around 17-15 Ma. It is, however, not possible to determine precisely to which pressure the obtained ages are associated.

\subsection{From P-T-t to P-T-D-t: Structures Accommodating the Exhumation}

[81] Structural studies have identified several structures that could have accommodated the exhumation of the Ama Drime rocks and surrounding units since $\sim 30 \mathrm{Ma}$. The first main structures are the MCTs (HHT/MCTu and MCT/MCTl) that do not outcrop in the Ama Drime area (Figure 1b), but that most probably prolongate below (Figure 1c). The STDS that lies immediately north of the investigated area may also have absorbed a significant part of the Ama Drime exhumation. Finally, N-S normal faults and shear zones on both side of the Ama Drime horst have absorbed the final exhumation of the Ama Drime rocks. A detailed analysis of the P-T paths and available geochronologic data allows deciphering of the timing and amount of exhumation linked with each structure.

\subsubsection{Differential Exhumations}

[82] All P-T paths of the Kharta area share a nearly isobaric heating prior to decompression. When timing constraints are available, this isobaric heating appears to starts at $\sim 30 \mathrm{Ma}$, corresponding to the Eo-Himalayan stage of metamorphism described elsewhere in the Himalayas. This event can be used as a reference for the relative exhumation amounts between the structural units of the Ama Drime area. For example the $\sim 0.2 \mathrm{GPa}$ pressure difference $(\sim 7.5 \mathrm{~km})$ observed between Saer and Kharta gives a first-order estimate of the differential exhumation absorbed within the Kharta-Saer unit below the STDSZ. Tibetan sedimentary series are epimetamorphic and have probably been exhumed by a very small amount since $12 \mathrm{Ma}$. Vertical exhumation linked with the STDSZ can thus be estimated from the STDSZ P-T path to be $\leq 0.6 \mathrm{GPa}(22 \mathrm{~km})$ at Saer (Figure 5c).

[83] The differential exhumation between the Ama Drime orthogneissic and paragneissic units appears very small, less than the uncertainty on the peak pressure of the ADO (Figures $5 \mathrm{~b}$ and $5 \mathrm{~d}$ ). There is thus no apparent motion on the Nyonno Ri boundary since more than $\sim 30 \mathrm{Ma}$.

\subsubsection{Exhumation Amounts at the Time of STDS Activity}

[84] As discussed previously (see section 5.2) motion along the STDS ended between 13.5 and 12 Ma near Saer [Leloup et al., 2009, 2010]. Such timing when compared with the P-T-t path of the Ama Drime orthogneissic unit implies that the adiabatic decompression, larger than $1.0 \mathrm{GPa}(37 \mathrm{~km})$ and most probably $\sim 1.3 \mathrm{GPa}(48 \mathrm{~km})$, occurred during normal motion on the STDS (Figure 5b). This interpretation differs significantly from that of Cottle et al. [2009], which relates the adiabatic decompression since $0.7-0.8 \mathrm{GPa}$ to normal motion on the Dinggye and Kharta shear zones. In our interpretation, the total exhumation linked to the Ama Drime horst is less than $0.4 \mathrm{GPa}(15 \mathrm{~km})$ (Figure 5b).

[85] The amount of exhumation linked with the STDS measured on the Ama Drime rocks P-T path is 0.2 to $0.7 \mathrm{GPa}$ higher than the $\leq 0.8 \mathrm{GPa}$ value obtained by summing 
the relative pressure differences from deformation below the STDSZ (0.2 GPa) and the STDSZ itself $(\leq 0.6 \mathrm{GPa}$, see section 5.3.1). This discrepancy may have several causes:

[86] 1. Vertical motion could have occurred at the base of the Kharta unit and above the Ama Drime orthogneissic unit for example on the Nyonno Ri Boundary. However, as discussed above, such motion, if any, is probably small.

[87] 2. Increase of the dip of the STDS (and MCT) toward the south could induce rotation of the HCS pile and larger uplift in the south than in the north. However, this last hypothesis is unlikely, as the STDS dips shallowly from the top of the Chomolangma to Rongbuk and appears to steepen, not flatten, farther north (Dzakar Chu section) (Figure 2a).

[88] 3. The differential estimates are only first order as they are based on global P-T path from whole units.

[89] 4. A combination of these causes.

[90] The amount of adiabatic decompression appears to increase away from the STD: $\sim 1.3 \mathrm{GPa}$ in the Ama Drime orthogneissic unit, 0.6 in the Ama Drime paragneisses, $0.5 \mathrm{GPa}$ in the Kharta gneiss and no adiabatic decompression in the STDSZ (Figure 5). This could be interpreted as a progressive decrease of the exhumation linked with the STDS together with the structural height, implying a distribution of down to the north deformation within the whole UHCS metamorphic pile. However, the end of the adiabatic decompression was reached at $\sim 16 \mathrm{Ma}$ in the Kharta unit (Figure 5a), at least $2 \mathrm{Ma}$ earlier than in the Ama Drime orthogneissc unit (Figure 5b). This is probably due to the fact that close to the surface $(\leq 0.4 \mathrm{GPa}$ or depths $\leq 15 \mathrm{~km})$ the thermal gradient is so steep, because temperature at the surface is low, that even fast exhumation cannot stay adiabatic but is necessarily accompanied by cooling. As a matter of fact, gneiss in the STDSZ never experienced adiabatic exhumation (Figure 5c) because they are located at the top of the metamorphic pile. It follows that most, of the exhumation (and cooling) of the Kharta unit occurred coevally with the STDS (Figure 5a), and that in the Ama Drime paragneissic unit, the amount of exhumation syn- and postSTDS are probably on the same order of the Ama Drime orthogneissic unit (Figure 5d).

[91] We estimate that, between $\sim 30$ and $12 \mathrm{Ma}, \leq 0.6 \mathrm{GPa}$ $(\leq 22 \mathrm{~km})$ of vertical exhumation occurred linked to brittle motion on the STD and ductile deformation in the STDSZ. This corresponds to exhumation rates on the order of $\leq 1.2 \mathrm{~mm} / \mathrm{yr}$ immediately below the STDS. This would correspond to $\leq 125 \mathrm{~km}$ of displacement and a shear rate of $\leq 7 \mathrm{~mm} / \mathrm{yr}$ on the STDS, assuming a regular dip of $10^{\circ}$ and simple shear in the STDSZ. During the same time span, units within the Ama Drime horst experienced the largest exhumation (1.0 to $1.5 \mathrm{GPa}, 37$ to $56 \mathrm{~km}$ ) corresponding to vertical rates of 2 to $3 \mathrm{~mm} / \mathrm{yr}$. Such exhumation occurred while HCS rocks, at the exclusion of amphibolite levels, were partially molten following a phase of isobaric heating. 5.3.3. Exhumation Mechanisms at the Time of STDS Activity

[92] Thrust imbrications, wedge extrusion and postthickening thermal reequilibration have been proposed as the main mechanisms for burial, heating and exhumation of HCS rocks. For some, internal deformations within the Himalayan thrust system could explain the STDS geometry
[Webb et al., 2007]. Other consider a larger thrust wedge system whose shape may vary significantly from one author to the other, being a few tenth of kilometers [Burchfiel and Royden, 1985; Grujic et al., 1996] to more than $120 \mathrm{~km}$ long [Guillot and Allemand, 2002]. Alternatively other authors consider that HCS rocks have been expulsed from farther north, below the Tibetan Plateau, through ductile channel flow following crustal melting [Beaumont et al., 2001; Grujic et al., 2002; Jamieson et al., 2004].

[93] In all these models, exhumation of the HCS occurs coevally with normal motion along the STDS, but amount of motion on the STDS vary widely. In the thrust system hypothesis, motion on the STDS can be very small $(\leq 30 \mathrm{~km})$ and is localized in a narrow shear zone [Webb et al., 2007]. At the opposite, STDS amount of motion is much larger in the channel flow hypothesis, on the same order of magnitude as motion on the MCT (some hundreds of $\mathrm{km}$ ), but deformation could be distributed in all the upper half of the channel. Timing and throw estimates of the MCTs and STDS are thus crucial to decipher between the models.

[94] Given its dip to the north, the MCT is probably located only $220 \mathrm{~km}$ below Kharta (Figure 1c). Age of motion along the MCT (MCT1) and HHT (MCTu) has been constrained through dating of the metamorphic evolution of the HCS gneisses and migmatites affected by top-to-thesouth high-temperature thrusting [Hodges et al., 1996; Vance and Harris, 1999; Walker et al., 1999; Foster et al., 2000; Simpson et al., 2000; Johnson et al., 2001; Viskupic and Hodges, 2001; Catlos et al., 2001, 2002a, 2002b, 2004; Kohn et al., 2005; Martin et al., 2007]. Ages were obtained by $\mathrm{U}-(\mathrm{Th})-\mathrm{Pb}$ method on zircon in leucosome and on monazite in leucosome, matrix or as inclusion within garnet (see Kohn et al. [2005] for a review). Ages interpretation has been widely discussed, especially for monazite (see Catlos et al. [2004] and Kohn et al. [2005] for a review). Based on their Y and Th content and textural relationships, monazite age has been either associated with leucosome crystallization or crystal formation during garnet growth, this latter mostly occurring during temperature increase (prograde evolution). Considering the various published ages it appears that temperature increase of the HCS gneisses occurred between $\sim 40$ and $16 \mathrm{Ma}$ and that crystallization of melt produced during this temperature increase occurred between 18 and $10 \mathrm{Ma}$ [Hodges et al., 1996; Walker et al., 1999; Foster et al., 2000; Simpson et al., 2000; Johnson et al., 2001; Viskupic and Hodges, 2001; Catlos et al., 2001, 2002a, 2002b, 2004; Kohn et al., 2005; Martin et al., 2007]. Coupling these dating with the P-T evolution of the HCS gneisses and migmatites places some constraints on the age of their exhumation and thus on the extrusion between the MCTl and or MCTu and the STDS. The P-T evolution is characterized by a strong decompression starting at $\sim 1 \mathrm{GPa}$ [Vance and Mahar, 1998; Guillot, 1999; Searle et al., 1999, Vannay et al., 1999; Goscombe and Hand, 2000; Kohn et al., 2001; Borghi et al., 2003; Dasgupta et al., 2004; Harris et al., 2004]. During this event the rocks keep heating as the thickened Indian continental crust has not yet reached thermal equilibrium and exhumation rate are slow enough [Thompson and Connolly, 1995]. Consequently, monazite crystallization might still occur during exhumation, especially if the mus- 
covite dehydration melting reaction is reached which is the case during decompression and heating for the migmatitic samples [Guillot, 1999; Searle et al., 1999, Goscombe and Hand, 2000; Borghi et al., 2003; Dasgupta et al., 2004; Harris et al., 2004]. Actually, petrogenetic modeling by Harris et al. [2004] evidences that significant garnet crystallization occurred when this reaction was reached. Thus, the ages of the prograde monazites are an upper bound for the exhumation of the HCS, i.e., between 40 and $16 \mathrm{Ma}$. Coupling the age of the prograde evolution and of the melt crystallization gives an interval for the age of melting. Detailed study by Kohn et al. [2005] in central Nepal (Langtang area) suggests that this event took place at $20 \pm$ 2 Ma for the northern part of the HCS, between the STDS and the Langtang thrust, the possible westward prolongation of the Barun thrust (HHT or MCTu), and at $15 \pm 2 \mathrm{Ma}$ for the southern part, between the MCTu and the MCTl. Similar age pattern was also evidenced by Catlos et al. [2004] in NE India (Sikkim). Altogether this suggests that the MCTu was active at and before $20 \pm 2 \mathrm{Ma}$ and the MCTl at and before $15 \pm$ $2 \mathrm{Ma}$. Consequently, MCTl and MCTu are most probably active during the adiabatic decompression event recorded by the Ama Drime rocks (see section 5.2) as well as during STDS activity.

[95] Cessation of top-to-the-south thrusting within the HCS gneisses and migmatites and of significant motion along MCTl and MCTu is indirectly constrained by the age of the top-to-the-south thrusting in the Lesser Himalaya unit, below the MCTl, associated with Main Boundary Thrust (MBT) activation. This shift is supposed to occur around 8-12 Ma [Harrison et al., 1997; Catlos et al., 2001, 2002a, 2002b; Daniel et al., 2003; DeCelles et al., 2001; Kohn et al., 2004] coevally with MBT activation at $\sim 11 \mathrm{Ma}$ [Meigs et al., 1995]. This southward migration of deformation localization is also supported by the detrital record in the Nepalese Siwalik, suggesting a change of sediment provenance indicating erosion of the Lesser Himalayan at 10-12 Ma [Szulc et al., 2006]. Thus, the cessation of thrusting along MCTl seems to be coeval with the end of most of the STDS deformation. Note that possible Pliocene reactivation of the $\mathrm{MCTl}$ in central Nepal was proposed by Macfarlane [1993] and Catlos et al. [2001].

[96] Throw on the MCTl in Nepal has been estimated to be between 140 and $210 \mathrm{~km}$ [Schelling and Arita, 1991; Schelling, 1992] or $200 \mathrm{~km}$ [Hauck et al., 1998]. More recently, DeCelles et al. [2001] have raised this estimate to $\sim 500 \mathrm{~km}$. Our estimate of the offset on the STDS of only $\leq 125 \mathrm{~km}$ appears significantly lower than thrusting on the $\mathrm{MCTl}$, even when neglecting possible thrusting on the $\mathrm{MCTu}$. This implies that either the whole HCS does not exhumed as a single coherent bloc or as proposed by Webb et al. [2007] that both the HCS and the Tethyan Series are transported southward over the MCT.

[97] Numerical models of channel flow in the Himalayan orogeny show that rocks initially buried at depth less than $1.35 \mathrm{GPa}$ can be brought to the surface above the MCTl [Jamieson et al., 2004]. This depth, which corresponds to the base of the horizontal ductile channel below Tibet, is broadly compatible with the metamorphic grade of the HCS near the MCTl, and thus appear to confirm the model
[Jamieson et al., 2004]. However, because the channel flattens to the north and is horizontal below Tibet, there is no reason to expect exhumation of deeper rock anywhere within the channel. Late exhumation in the Ama Drime horst has brought to the surface rocks that were at $15 \mathrm{~km}$ depth at the end of motion on the STDS (see section 5.3.3). This gives us access to the deep part of wedge/channel $\sim 140 \mathrm{~km}$ north of the emergence of the MCTl (Figure 1c). The Ama Drime orthogneissic unit has been buried to depth $\geq 52 \mathrm{~km}(\geq 1.4 \mathrm{GPa})$ and exhumed more than $1 \mathrm{GPa}(37 \mathrm{~km})$ below the STDS, while the overlying Ama Drime paragneissic unit has been buried to $1.6 \mathrm{GPa}(60 \mathrm{~km})$. Such depths would thus correspond to rocks from below the channel (i.e., below the MCTl). This would imply that most of the HCS rocks do not correspond to the channel and that the MCT1 and the whole channel would now be exposed above T5D33 locality, thus north of the Sangkar Ri. This corresponds to a maximum thickness of the channel of only 1.3 to $4 \mathrm{~km}$ (15 km distance for $10^{\circ} \pm 5^{\circ} \mathrm{dip}$ ) (Figure $2 \mathrm{a}$ ). Furthermore, most of the exhumation (37 to $48 \mathrm{~km}$ ) took place between the MCTI and STDS, that thus did not bound a horizontal channel at that time. It also appears that, even it has been largely migmatized, the Ama Drime orthogneissic unit represents a coherent unit as metabasite layers can be followed without interruption for distances of few kilometers (Figure 3e). The large-scale folds affecting these layers are more compatible with vertical thinning and/or N-S simple shear rather than with a partially molten medium that would have flowed for some hundreds of kilometers.

[98] It is logical that rocks sampled deeper in a given thrust slice have experienced higher-pressure conditions. In that case the maximum possible pressure corresponds to the minimum rooting depth of the thrust system, or thrust wedge, and the horizontal pressure gradient in a given thrust sheet may be used to evaluate the dipping angle of the underlying thrust system. In the case of the Ama Drime, this would imply that the MCT-MHT system roots at more than $52-63 \mathrm{~km}$ depth and dips $6-9^{\circ}$ to the north, which is in good accordance with the value proposed from geophysical evidences [e.g., Makovsky et al., 1996].

\subsubsection{Final Exhumation of the Ama Drime Horst}

[99] As previously discussed, deformation started prior to $\sim 11 \mathrm{Ma}$ in the Dinggye shear zone (age of T5D5 crosscutting dike, see sections 4.2 .1 and 5.2). The $\sim 0.4 \mathrm{GPa}$ of exhumation $(15 \mathrm{~km})$ of the Ama Drime unit orthogneissic unit that occurred during the last $\sim 12 \mathrm{Ma}$ are thus related to ductile and brittle motion along the N-S Kharta and Dinggye shear zones and the formation of the Ama Drime horst (Figure 5b). This estimate suggests an average exhumation rate of $\sim 1.2 \mathrm{~mm} / \mathrm{yr}$. The vertical offset of the STD is of 4.4 to $9.4 \mathrm{~km}$ at the northern tip of the Ama Drime (see section 3.2.1) (Figure 2a). This is coherent with a progressive decrease of the finite motion toward the northern tip of the Dinggye fault. Fifteen $\mathrm{km}$ of exhumation could have been sufficient to bring the MCTu at the surface, confirming that the Nyonno Ri Boundary could be an equivalent of the Barun thrust that separates the LHCS and the GHCS.

[100] (U-Th)/He apatite ages collected at various locations within the horst [Jessup et al., 2008; this study] appear to give a coherent picture corresponding to vertical exhuma- 


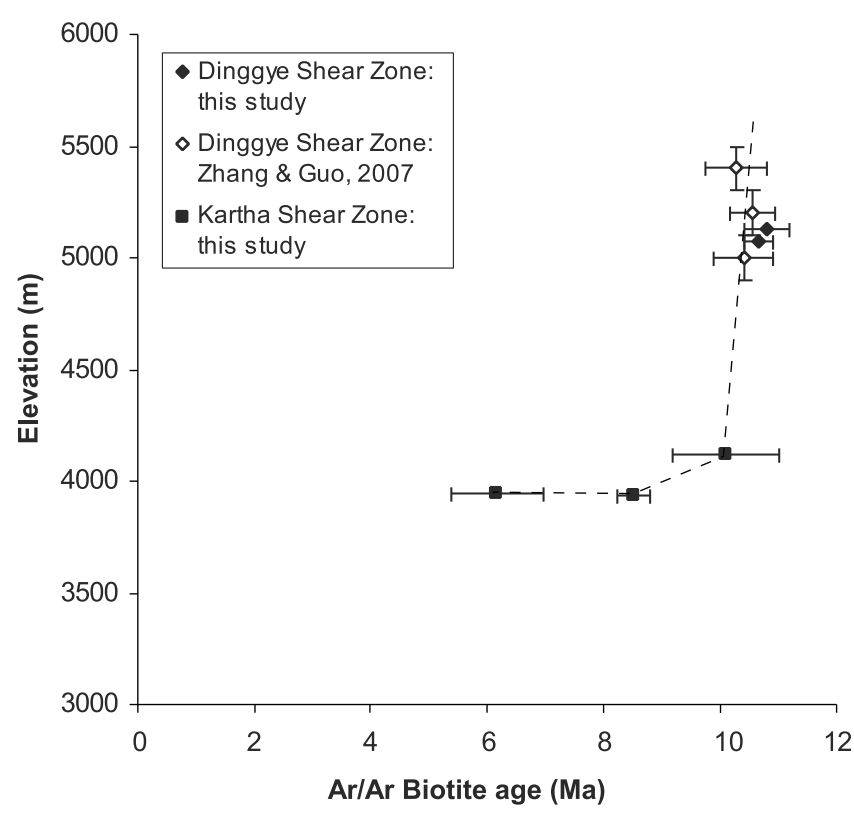

Figure 11. Plot of Ama Drime Ar/Ar biotite age versus elevation. Data from this study (Table 3), and Zhang and Guo [2007]. Elevation of Zhang and Guo [2007] samples has been inferred from SRTM digital elevation model and was attributed a conservative $1 \sigma$ uncertainty of $100 \mathrm{~m}$. This plot suggests that exhumation rate was very fast at $\sim 10 \mathrm{Ma}$ and then significantly slowed down at least until $6 \mathrm{Ma}$. See text for details.

tion at about $1 \mathrm{~mm} / \mathrm{yr}$ since at least $4.2 \mathrm{Ma}$ (see section 4.2.4, Figure 10). This corresponds to $\sim 4 \mathrm{~km}$ of vertical exhumation. All (U-Th)/He data fit in the same trend suggesting that there is no differential exhumation across the horst. The straightforward interpretation is that the two active faults bounding the horst are active since at least 4.2 Ma with vertical slip rates of $\sim 1 \mathrm{~mm} / \mathrm{yr}$.

[101] Both active faults exhibit ductile shear zones in their footwall. The fact that the motion direction on the ductile mylonites and brittle faults are the same (Figure 4) favors the interpretation of one continuous phase of deformation, as it is classically interpreted in metamorphic core complexes. In that case, initial exhumation related to ductile deformation would have started at a fast rate of at least $1.4 \mathrm{~mm} / \mathrm{yr}$ and would have slowed down to $\sim 1 \mathrm{~mm} / \mathrm{yr}$ in the last $4 \mathrm{Ma}$ in order to reach an average rate of $\sim 1.2 \mathrm{~mm} / \mathrm{yr}$. [102] Total exhumation of $\sim 15 \mathrm{~km}$ would correspond to $\sim 21 \mathrm{~km}$ displacement on the Dinggye shear zone (dip $\sim 45^{\circ}$ ), and $\sim 30 \mathrm{~km}$ on the Kharta one (dip $\sim 30^{\circ}$ ). This implies that $41 \mathrm{~km}$ (measured horizontally, parallel to the motion direction) of the hanging plates would have been eroded. Following the interpretation that part of the Ama Drime orthogneissic unit adiabatic decompression is contemporaneous with E-W extension, and not with the STDS, would increase the vertical exhumation to $24 \pm 2 \mathrm{~km}$ [Cottle et al., 2009]. The amount of removed upper plate would thus rise to 60 to $71 \mathrm{~km}$. Such estimates are problematic as the two faults are only $28 \mathrm{~km}$ away from each other, leaving place for a maximum $28 \mathrm{~km}$ of removed upper plate. In order to stay compatible with $15 \mathrm{~km}$ of exhumation both faults should dip by $47^{\circ}$ to $52^{\circ}$, and join at the surface at the onset of deformation. Conversely, maximum possible exhumations for faults dipping $30^{\circ}$ and $45^{\circ}$ are $14 \mathrm{~km}$ and $8 \mathrm{~km}$, respectively. It thus appears that the structural history of the Ama Drime horst is more complicated, either that the fault have not been synchronous and/or that their dip was significantly larger than the present dip of the mylonites.

[103] Ductile deformation in the Dinggye shear zone started prior to $\sim 11 \mathrm{Ma}$ and stopped at $\sim 10 \mathrm{Ma}$, as temperature had dropped below $\sim 300^{\circ} \mathrm{C}$ according to the biotite and muscovite argon ages (Figure 9). The age of the Kharta shear zone is much less well constrained. The fact that all leucocratic dikes are deformed in the Kharta SZ while many of them crosscut the Dinggye SZ (Figure 2b) could suggest that ductile deformation initiate later, or lasted longer, on the western side than on the eastern one. Such dikes are dated between $12.8 \pm 0.2$ and $9.8 \pm 1.2 \mathrm{Ma}$ (Figure 9), suggesting that the main ductile deformation event could have occurred prior to $\sim 10 \mathrm{Ma}$ in the Dinggye SZ and after that date in the Kartha SZ. On the other hand, $\sim 12$ Ma muscovite and $\sim 10$ Ma biotite ${ }^{39} \mathrm{Ar} /{ }^{40} \mathrm{Ar}$ ages could suggest that ductile deformation was active in the Kharta shear zone in the 12$10 \mathrm{Ma}$ interval coevally with the Dinggye SZ. However, ${ }^{39} \mathrm{Ar} /{ }^{40} \mathrm{Ar}$ ages in the Kharta SZ span between 24 and $3 \mathrm{Ma}$ (Table 3 and Figure 9) and another interpretation can be proposed. T7A19 meta-arenite biotite ${ }^{39} \mathrm{Ar}{ }^{40} \mathrm{Ar}$ age $(23.5 \pm$ $0.5 \mathrm{Ma}$ ) is interpreted as inherited from the peak temperature

Figure 12. Speculative sketches of exhumation phases of the Ama Drime rocks. Schematic drawings depicting the main exhumation phases of the Ama Drime rocks. The burial stage (prograde metamorphism) is not depicted. Drawings have been oversimplified in order to highlight structures related to the exhumation of the Ama Drime. The topographic profiles are arbitrary for Figures 12a and 12b and based on SRTM data for Figure 12c. Shaded color above topography. ADO, Ama Drime orthogneissic unit; ADP, Ama Drime paragneissic unit. Figures 12a-12c show the main exhumation stages, with cross section(s) (left) and corresponding P-T path for the Ama Drime pragneisses (top right) and orthogneisses (bottom right). For Figures $12 \mathrm{~b}$ and $12 \mathrm{c}$, two cross sections are presented: NNE-SSW parallel to Figure $2 \mathrm{~b}$ but going through Ama Drime range (left) and east-west across the south Ama Drime (middle). In each case the arrow corresponds to the path during the whole time interval. (a) Exhumation in the hanging wall of the lower MCT-MHT and in the footwall of the STDS, between $\sim 33$ and $12 \mathrm{Ma}$. This is the main exhumation phase during which both units are partially melted. Timing of exhumation initiation is not precisely constrained. The upper MCT-HHT is probably active only during a limited time. KT, Kangmar thrust; CT, counterthrust. (b) Exhumation in the footwall of the Kharta and Dinggye shear zones. The Dinggye shear zone was probably the master fault and is figured in bold. (c) Exhumation in the footwall of the Kharta and Dinggye faults. 


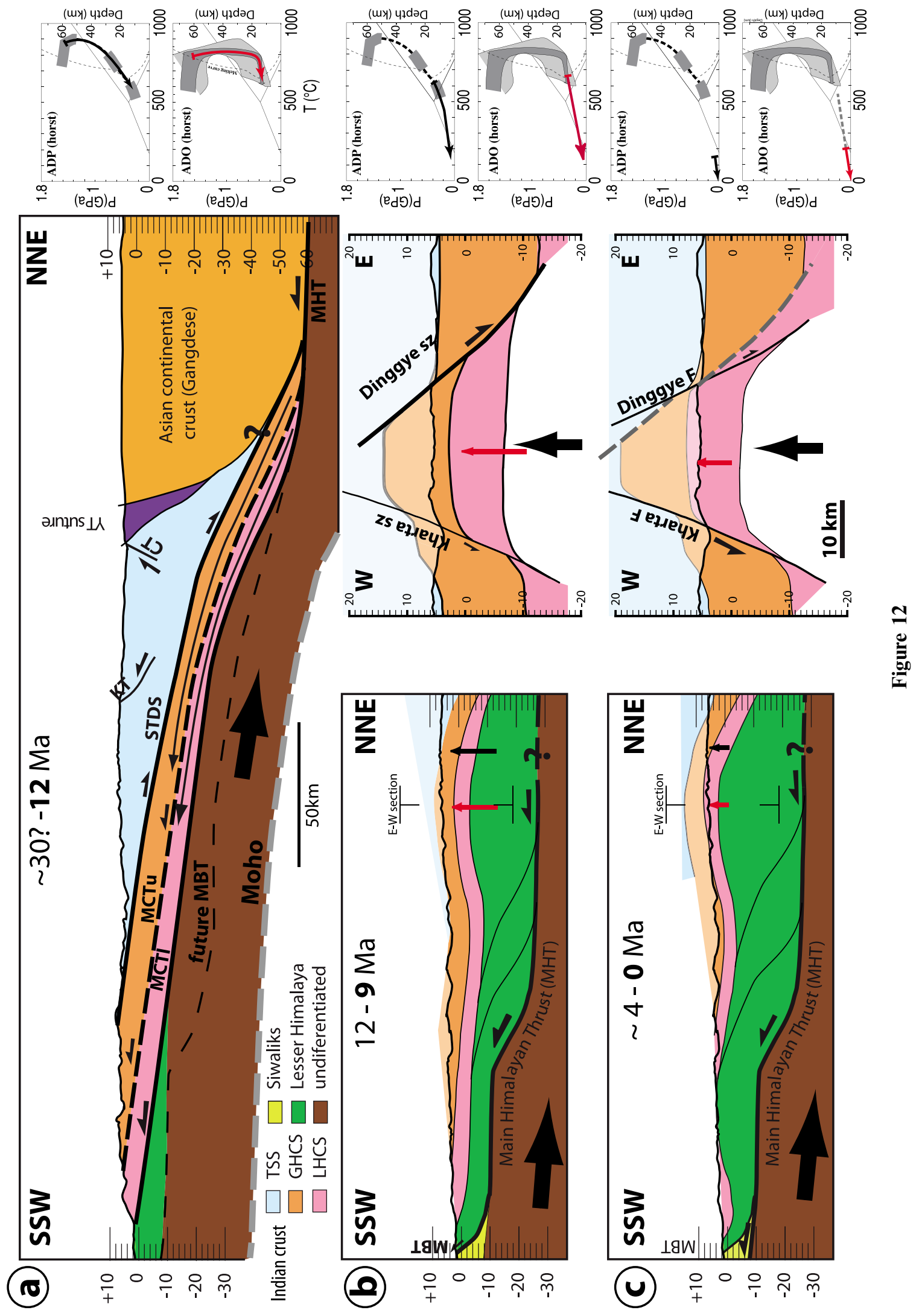


metamorphism in the Ama Drime series (see section 4.2.2). When plotted against elevation, the other ${ }^{39} \mathrm{Ar} /{ }^{40} \mathrm{Ar}$ biotite argon ages suggest a slow exhumation rate in the Kharta shear zone from $\sim 10$ to $\sim 6 \mathrm{Ma}$ (Figure 11). The same plot for the Dinggye shear zone confirms fast exhumation at $\sim 10.5 \mathrm{Ma}$. (Figure 11). Together with the (U-Th)/He data, this could imply two pulses of rapid cooling and exhumation for the Ama Drime horst: one at $\sim 10 \mathrm{Ma}$ and another since $\sim 4 \mathrm{Ma}$. In that case the biotite ages of the western flank would be interpreted as cooling ages and the muscovite ages as reflecting deformation phases at $\sim 12 \mathrm{Ma}$ and since $\sim 6 \mathrm{Ma}$ (Figure 9). In the Dinggye SZ the ${ }^{39} \mathrm{Ar} /{ }^{40} \mathrm{Ar}$ biotite and muscovite ages are the same (Figure 9) suggesting a major cooling and deformation phase between 13.7 and 10.2 Ma.

[104] We propose that two successive normal faulting events took place in the Ama Drime massif. At $\sim 12 \mathrm{Ma}, \mathrm{E}-\mathrm{W}$ extension immediately following the end of motion on the STDS induced the formation of the Dinggye shear zone and induced rapid cooling and exhumation $(\sim 4 \mathrm{~mm} / \mathrm{yr})$ on the eastern side of the range (Figure 12b). Exhumation (and cooling) was probably slower on the western side resulting in a more complex thermochronologic signal. This could indicate that the master fault was on the eastern side, a fact that could explain the bulge of the STD observed to the NW of the Ama Drime. By $10 \mathrm{Ma}$ temperature was below $300^{\circ} \mathrm{C}$ in the Dinggye shear zone. That deformation phase ended $\sim 9 \mathrm{Ma}$ ago, and induced 11 to $13 \mathrm{~km}$ of exhumation. Prior to $4 \mathrm{Ma}$ ago, probably at $\sim 6 \mathrm{Ma}$, two conjugate $\mathrm{N}-\mathrm{S}$ normal faults affected the Ama Drime range, inducing exhumation at a rate of $\sim 1 \mathrm{~mm} / \mathrm{yr}$, for a total of at least $4 \mathrm{~km}$ (Figure 12c). Hydrothermal circulation along brittle faults induced the crystallization of a second generation of muscovites near the Kharta fault (Figure 9). The late normal faults belong to the Xainza-Dinggye fault system and are contemporaneous with the major east-west extensional episode recognized in numerous localities in southern Tibet (e.g., Mahéo et al. [2007] for a review). This structural history, compatible with presently available data would need to be tested at the light of new data.

[105] In any case the onset of E-W extension appears to closely follow or to be contemporaneous with the time of the end of motion along the STDS and MCTl between 12 and $10 \mathrm{Ma}$. This brutal transition from $\mathrm{N}-\mathrm{S}$ to $\mathrm{E}-\mathrm{W}$ extension in south Tibet while $\sim \mathrm{N}-\mathrm{S}$ convergence still takes place between India and Eurasia has to be explained.

[106] In a context of $\sim \mathrm{N}-\mathrm{S}$ shortening, north south trending normal faults can be related (1) with east-west extension during orogen parallel midcrustal flow [Cottle et $a l ., 2009]$, (2) stress reorganization(s) related with kinematics and/or geometry change(s) of the underlying thrust system and (3) focused erosion of the Arun River [Jessup et al., 2008].

[107] Focused erosion of the Arun River can be ruled out as the river is not centered on the massif, where the deepest rocks outcrop, but flows in the half graben located along the western flank of the massif. Possible recent migration of the river from the core of the horst to its present-day location, is unlikely as (1) focused erosion implies deep incision incompatible with significant river migration, and (2) (U-Th)/
He data indicates constant exhumation with no significant tilting since at least $4 \mathrm{Ma}$.

[108] The exact distribution of the early (12-10 Ma) phases of $\mathrm{E}-\mathrm{W}$ extension is not yet well recognized. It starts to be documented in few localities through Tibet: in the Thakkhola graben [Garzione et al., 2003], in Tangra Yum Co [Dewane et al., 2006], Lopu fault [Arnaud et al., 2008] as well as in the Xainza Rift [Hager et al., 2006] in the northern prolongation of the Dinggye fault. In all these localities the exhumation seems to last less than $2 \mathrm{Myr}$ [Hager et al., 2006]. Some have proposed that, at the scale of Tibet, crustal flow toward the south (Himalaya) was followed by crustal flow toward the east (LongmenShan and Yunnan) that would still be active today [e.g., Royden et al., 1997]. In that context, the switch from N-S to E-W extension in the Ama Drime would correspond to the change in direction of the channel flow [Cottle et al., 2009]. However, the reason(s) for such radical change, and for the occurrence of two distinct phases of extension rather than a continuous one, would stay mysterious as the main boundary conditions driving channel flow (thermal state of the crust beneath Tibet and topography) do not appear to have radically changed at that time. Furthermore, the direction of extension in the Ama Drime area is neither perpendicular to the regional high topography nor directed toward the region where crustal flow is expected to leave Tibet north of the eastern syntaxis.

[109] On the other hand the timing of the end of motion along the MCTl appears closely related to the activation of the Main Boundary Thrust (Figures 12a and 12b). This corresponds to the propagation of surface expression of the deep main Himalayan thrust (MHT) toward the external part or the accretionary prism, as it is classically observed in many mountain belts. From plate kinematics reconstruction based on magnetic anomalies, Lee and Lawver [1995] infer a change in India-Eurasia convergence direction from $\sim \mathrm{N} 30$ to $\sim \mathrm{N} 13$ at $10-12 \mathrm{Ma}$ together with a slight increase in rate. Using a different plate circuit, Molnar and Stock [2009] infer a $\geq 40 \%$ rate decrease together with a direction change between 20 and $\sim 10 \mathrm{Ma}$. From their data, the change may have occurred gradually or abruptly near $11 \mathrm{Ma}$. The timing coincidence suggest that changes in the locus, direction and rate of thrusting at $\sim 11$ Ma may have annihilate the conditions favorable for slip of a passive roof fault (The STDS) along the top of the prism, and locally promoted $\sim \mathrm{E}-\mathrm{W}$ extension. We also note that the Molnar and Stock [2009] plate reconstruction shows a constant convergence rate since $\sim 10 \mathrm{Ma}$ but a marked change in direction between $\sim 5$ and $\sim 6 \mathrm{Ma}$ ago, at the time that we infer for the initiation of the still active $\mathrm{E}-\mathrm{W}$ extension phase that has been interpreted as directly related to India punch [Armijo et al., 1986; McCaffrey and Nabelek, 1998; Kapp and Guynn, 2004]. We thus propose that south Tibet Cenozoic extension phases kinematics are fundamentally drived by the direction and rate of India underthrusting.

\subsection{Conclusion and Summary}

[110] From the observations and interpretations presented above the structural and metamorphic evolution of the Ama 
Drime range can be summarized as follows. In the Ama Drime range, both the Ama Drime orthogneissic and paragneissic unit where buried to depth of 52 to $63 \mathrm{~km}$. Most of the exhumation corresponds to an adiabatic decompression of 37 to $48 \mathrm{~km}$, initiated after $33 \mathrm{Ma}$, between the MCTs and the STDS until $\sim 13.5 \mathrm{Ma}$ (Figure 12a). That phase ended when motion along the STDS switched to local E-W extension between 13.5 and $12 \mathrm{Ma}$. This timing is compatible with a contemporaneous end of the STDS and the MCTl motion at $\sim 12$ Ma. Vertical exhumation in the STDSZ and below the STD is smaller than $0.6 \mathrm{GPa}(22 \mathrm{~km})$, corresponding to $\sim 125 \mathrm{~km}$ of displacement and a rate of $\sim 7 \mathrm{~mm} / \mathrm{yr}$ on the STDS between $\sim 30$ and $\sim 12 \mathrm{Ma}$. During the same time span, further 0.3 to $0.7 \mathrm{GPa}(11$ to $26 \mathrm{~km})$ of exhumation occurred below the STDSZ probably above the MCTl. The coeval end of motion on the STDS and MCTl, and the fact that the HCS rocks were partially molten at the time of their exhumation appear compatible with the lower crustal flow hypothesis. However, the fact that motion on the STDS is much smaller than on the MCTl and that rocks have been exhumed from greater depths than those envisaged for the channel model are more compatible with a wedge extrusion or thrust system model. In that case, the change of direction of extension at the top of the belt was triggered by propagation of thrusting from the MCTl to the lower and more external MBT. While exhumation may have been continuous since $\sim 12 \mathrm{Ma}$, some clues suggest that it took place in two distinct phases: (1) The Dinggye normal shear zone was active until $\sim 9 \mathrm{Ma}$, accounting for 9 to $12 \mathrm{~km}$ of exhumation (Figure 12b), and (2) final exhumation of the Ama Drime horst along the Dinggye and Kharta normal faults from $\sim 6$ to $4 \mathrm{Ma}$ to present at a vertical rate of $\sim 1 \mathrm{~mm} / \mathrm{yr}$ (Figure 12c). The fact that the Arun River flows outside of the Ama Drime horst excludes that it may have played a major role in the exhumation of the range.

[111] Acknowledgments. We thank E. Deloule and the ion probe team of the CRPG, CNRS UPR 2300, Nancy, France, for their help in dating the zircons. Claude Merlet and the electronic microprobe team of Géosciences Montpellier, Université de Montpellier 2, France. We thank Paul Capiez for the whole rock X-fluorescence analysis at UMR 5570, Lyon, France. This paper benefited for constructive review by C. Groppo and one anonymous reviewer. The first field trip was financed by INSU DyETI grant to R. Lacassin and P.H.L. This project has benefited from the SinoFrench PRA program to D.L. and J.V.W.

\section{References}

Arita, K. (1983), Origin of the inverted metamorphism of the Lower Himalayas, central Nepal, Tectonophysics, 95, 43-60, doi:10.1016/0040-1951(83) 90258-5.

Armijo, R., P. Tapponnier, J. L. Mercier, and T. L. Han (1986), Quaternary extension in southern Tibet: Field observations and tectonic implications, J. Geophys. Res., 91, 13,803-13,872, doi:10.1029/ JB091iB14p13803.

Arnaud, N., J. C. Aitchison, P. H. Leloup, F. Valli, and S. Wilde (2008), Constraints on the initiation of normal faulting across the Yarlung Tsangpo suture zone, from the Lopu Gangri range, southern Tibet, Geophys. Res. Abstr., 10, EGU2008-A-00000.

Auzanneau, E., D. Vielzeuf, and M. W. Schmidt (2006), Experimental evidence of decompression melting during exhumation of subducted continental crust, Contrib. Mineral. Petrol., 152, 125-148, doi:10.1007/s00410-006-0104-5.

Baur, J. R. (2007), Seismotectonics of the Himalayas and the Tibetan Plateau: Moment tensor analysis of regional seismograms, Ph.D. thesis, $298 \mathrm{pp}$, Oreg. State Univ., Corvallis.

Beaumont, C., R. A. Jamieson, M. H. Nguyen, and B. Lee (2001), Himalayan tectonics explained by extrusion of a low-viscosity crustal channel coupled to focused surface denudation, Nature, 414 738-742, doi:10.1038/414738a.

Bollinger, L., J. P. Avouac, O. Beyssac, E. J. Catlos, T. M. Harrison, M. Grove, B. Goffe, and S. Sapkota (2004), Thermal structure and exhumation history of the Lesser Himalaya in central Nepal, Tectonics, 23, TC5015, doi:10.1029/2003TC001564.

Bordet, P. (1961), Recherches Géologiques dans l'Himalaya du Népal, Région du Makalu, 275 pp., Cent. Natl. de la Rech. Sci., Paris.

Borghi, A., D. Castelli, B. Lombardo, and D. Visona (2003), Thermal and baric evolution of garnet granulites from the Kharta region of S Tibet, $\mathrm{B}$ Himalaya, Eur. J. Mineral., 15, 401-418, doi:10.1127/0935-1221/2003/0015-0401.

Brunel, M. (1983), Etude Pétro-Structurale des Chevauchements Ductiles en Himalaya (Népal Oriental et Himalaya du Nord-Ouest), 395 pp., Univ. of Paris VII, Paris.

Burchfiel, B. C., and L. H. Royden (1985), North-south extension within the convergent Himalayan region,
Geology, 13, 679-682, doi:10.1130/0091-7613 (1985) $13<679: \mathrm{NEWTCH}>2.0 . \mathrm{CO} ; 2$.

Burchfiel, B. C., Z. Chen, K. V. Hodges, Y. Liu, L. H. Royden, C. Deng, and J. Xu (1992), The South Tibetan Detachment System, Himalayan Orogen: Extension contemporaneous with and parallel to shortening in a collisional mountain belt, Spec. Pap. Geol. Soc. Am., 269, 41 pp.

Burg, J. P., M. Brunel, D. Gapais, G. M. Chen, and G. H. Liu (1984), Deformation of leucogranites of the crystalline main central sheet in southern Tibet (China), J. Struct. Geol., 6, 535-542, doi:10.1016/ 0191-8141(84)90063-4.

Carosi, R., B. Lombardo, G. Molli, G. Musumeci, and P. C. Pertusati (1998), The South Tibetan Detachment System in the Rongbuk valley, Everest region. Deformation features and geological implications, J. Asian Earth Sci., 16, 299-311, doi:10.1016/ S0743-9547(98)00014-2.

Castro, A., L. G. Corretge, M. El-Biad, H. El-Hmidi, C. Fernandez, and A. E. P. Douce (2000), Experimental constraints on Hercynian anatexis in the Iberian Massif, Spain, J. Petrol., 41, 1471-1488.

Catlos, E. J., T. M. Harrison, M. J. Kohn, M. Grove, F. J. Ryerson, C. E. Manning, and B. N. Upreti (2001), Geochronologic and thermobarometric constraints on the evolution of the Main Central Thrust, central Nepal Himalaya, J. Geophys. Res., 106, 16,177-16,204, doi:10.1029/2000JB900375.

Catlos, E. J., L. D. Gilley, and T. M. Harrison (2002a), Interpretation of monazite ages obtained via in situ analysis, Chem. Geol., 188, 193-215, doi:10.1016/ S0009-2541(02)00099-2.

Catlos, E. J., T. M. Harrison, C. E. Manning, M. Grove, S. M. Rai, M. S. Hubbard, and B. N. Upreti (2002b), Records of the evolution of the Himalayan orogen from in situ $\mathrm{Th}-\mathrm{Pb}$ ion microprobe dating of monazite: Eastern Nepal and western Garhwal, J. Asian Earth Sci., 20, 459-479, doi:10.1016/ S1367-9120(01)00039-6.

Catlos, E. J., C. S. Dubey, T. M. Harrison, and M. A. Edwards (2004), Late Miocene movement within the Himalayan Main Central Thrust shear zone, Sikkim, north-east India, J. Metamorph. Geol., 22, 207-226, doi:10.1111/j.1525-1314.2004.00509.x.

Cattin, R., and J. P. Avouac (2000), Modeling mountain building and the seismic cycle in the Himalaya of
Nepal, J. Geophys. Res., 105, 13,389-13,407, doi:10.1029/2000JB900032.

Connolly, J. A. D. (1990), Multivariable phase-diagrams - An algorithm based on generalized thermodynamics, Am. J. Sci., 290, 666-718.

Cottle, J. M., M. J. Jessup, D. L. Newell, M. P. Searle, R. D. Law, and M. S. A. Horstwood (2007), Structural insights into the early stages of exhumation along an orogen-scale detachment: The South Tibetan Detachment System, Dzakaa Chu section, eastern Himalaya, J. Struct. Geol., 29, 1781-1797, doi:10.1016/j.jsg.2007.08.007.

Cottle, J. M., M. J. Jessup, D. L. Newell, M. S. A. Horstwood, S. R. Noble, R. R. Parrish, D. J. Waters, and M. P. Searle (2009), Geochronology of granulitized eclogite from the Ama Drime Massif: Implications for the tectonic evolution of the south Tibetan Himalaya, Tectonics, 28, TC1002, doi:10.1029/ 2008TC002256

Daniel, C. G., L. S. Hollister, R. R. Parrish, and D. Grujic (2003), Exhumation of the Main Central Thrust from lower crustal depths, eastern Bhutan Himalaya, J. Metamorph. Geol., 21, 317-334.

Dasgupta, S., J. Ganguly, and S. Neogi (2004), Inverted metamorphic sequence in the Sikkim Himalayas: Crystallization history, P-T gradient and implications, J. Metamorph. Geol., 22, 395-412, doi:10.1111/j.1525-1314.2004.00522.x.

DeCelles, P. G., D. M. Robinson, J. Quade, T. P. Ojha, C. N. Garzione, P. Copeland, and B. N. Upreti (2001), Stratigraphy, structure, and tectonic evolution of the Himalayan fold-thrust belt in western Nepal, Tectonics, 20, 487-509, doi:10.1029/ 2000TC001226.

Dewane, T. J., D. F. Stockli, C. Hager, M. Taylor, L. Ding, J. Lee, and S. Wallis (2006), Timing of Cenozoic E-W Extension in the Tangra Yum Co-Kung Co Rift, south-central Tibet, Eos Trans. $A G U, 87(52)$, Fall Meet. Suppl., Abstract T34C-04

Dewey, J. F. (1988), Extensional collapse of orogens, Tectonics, 7, 1123-1139, doi:10.1029/ TC007i006p01123.

Edwards, M. A., W. S. F. Kidd, J. X. Li, Y. J. Yu, and M. Clark (1996), Multi-stage development of the southern Tibet detachment system near Khula Kangri. New data from Gonto La, Tectonophysics, 260, 1-19, doi:10.1016/0040-1951(96)00073-X 
England, P., and G. Houseman (1989), Extension during continental convergence, with application to the Tibetan Plateau, J. Geophys. Res., 94, 17,56117,579, doi:10.1029/JB094iB12p17561.

Foster, G., P. Kinny, D. Vance, C. Prince, and N. Harris (2000), The significance of monazite $\mathrm{U}-\mathrm{Th}-\mathrm{Pb}$ age data in metamorphic assemblages: A combined study of monazite and garnet chronometry, Earth Planet. Sci. Lett., 181, 327-340, doi:10.1016/ S0012-821X(00)00212-0.

Fraser, G., D. Ellis, and S. Eggins (1997), Zirconium abundance in granulite-facies minerals, with implications for zircon geochronology in high-grade rocks, Geology, 25, 607-610, doi:10.1130/00917613(1997)025<0607:ZAIGFM >2.3.CO;2.

Garzione, C. N., P. G. DeCelles, D. G. Hodkinson, T. P. Ojha, and B. N. Upreti (2003), East-west extension and Miocene environmental change in the southern Tibetan Plateau: Thakkhola graben, central Nepal, Geol. Soc. Am. Bull., 115, 3-20, doi:10.1130/ 0016-7606(2003)115<0003:EWEAME $>2.0 . C O ; 2$.

Goscombe, B., and M. Hand (2000), Contrasting P-T paths in the Eastern Himalaya, Nepal: Inverted isograds in a paired metamorphic mountain belt, J. Petrol., 41, 1673-1719, doi:10.1093/petrology/ 41.12.1673.

Goscombe, B., D. Gray, and M. Hand (2006), Crustal architecture of the Himalayan metamorphic front in eastern Nepal, Gondwana Res., 10, 232-255, doi:10.1016/j.gr.2006.05.003.

Groppo, C., B. Lombardo, F. Rolfo, and P. Pertusati (2007), Clockwise exhumation path of granulitized eclogites from the Ama Drime range (Eastern Himalayas), J. Metamorph. Geol., 25, 51-75, doi:10.1111/j.1525-1314.2006.00678.x.

Grujic, D., M. Casey, C. Davidson, L. S. Hollister, R. Kundig, T. Pavlis, and S. Schmid (1996), Ductile extrusion of the higher Himalayan crystalline in Bhutan: Evidence from quartz microfabrics, Tectonophysics, 260, 21-43, doi:10.1016/0040-1951 (96)00074-1.

Grujic, D., L. S. Hollister, and R. R. Parrish (2002), Himalayan metamorphic sequence as an orogenic channel: Insight from Bhutan, Earth Planet. Sci. Lett., 198, 177-191, doi:10.1016/S0012-821X(02) 00482-X.

Guillot, S. (1999), An overview of the metamorphic evolution in central Nepal, J. Asian Earth Sci., 17, 713-725, doi:10.1016/S1367-9120(99)00045-0.

Guillot, S., and P. Allemand (2002), Two-dimensional thermal modelling of the early tectonometamorphic evolution in central Himalaya, J. Geodyn., 34, 7798, doi:10.1016/S0264-3707(02)00016-9.

Hager, C., D. Stockli, T. Dewane, and L. Ding (2006), Episodic Mio-Pliocene rifting in south-central Tibet. Thermochronometric constraints from the Xainza rift, Eos Trans. AGU, 87(52), Fall Meet. Suppl., Abstract T34C-02.

Harris, N. B. W., M. Caddick, J. Kosler, S. Goswami, D. Vance, and A. G. Tindle (2004), The pressuretemperature-time path of migmatites from the Sikkim Himalaya, J. Metamorph. Geol., 22, 249264, doi:10.1111/j.1525-1314.2004.00511.x.

Harrison, T. M., P. Copeland, W. S. F. Kidd, and O. M. Lovera (1995), Activation of the Nyainqentanghla Shear Zone: Implications for uplift of the southern Tibetan Plateau, Tectonics, 14, 658-676, doi:10.1029/95TC00608.

Harrison, T. M., F. J. Ryerson, P. LeFort, A. Yin, O. M. Lovera, and E. J. Catlos (1997), A late MiocenePliocene origin for the central Himalayan inverted metamorphism, Earth Planet. Sci. Lett., 146, E1E7, doi:10.1016/S0012-821X(96)00215-4.

Harrison, T. M., M. Grove, O. M. Lovera, and E. J. Catlos (1998), A model for the origin of Himalayan anatexis and inverted metamorphism, J. Geophys. Res., 103, 27,017-27,032, doi:10.1029/98JB02468.

Hauck, M. L., K. D. Nelson, L. D. Brown, W. J. Zhao, and A. R. Ross (1998), Crustal structure of the Himalayan orogen at $\sim 90^{\circ}$ east longitude from Project INDEPTH deep reflection profiles, Tectonics, 17, 481-500, doi:10.1029/98TC01314.
Heim, A., and A. Gansser (1939), Central Himalaya: Geological 999 observations of the Swiss expedition 1936, Mem. Soc. Helv. Sci. Nat., 1-245.

Hodges, K. V. (2000), Tectonics of the Himalaya and southern Tibet from two perspectives, Geol. Soc. Am. Bull., 112, 324-350, doi:10.1130/0016-7606 (2000) $112<0324$ :TOTHAS $>2.3 . \mathrm{CO} ; 2$

Hodges, K. V., W. E. Hames, W. Olszewski, B. C. Burchfiel, L. H. Royden, and Z. Chen (1994), Thermobarometric and ${ }^{40} \mathrm{Ar} /{ }^{39} \mathrm{Ar}$ geochronologic constraints on Eohimalayan metamorphism in the Dinggyê area, southern Tibet, Contrib. Mineral. Petrol., 117, 151-163, doi:10.1007/BF00286839.

Hodges, K. V., R. R. Parrish, and M. P. Searle (1996), Tectonic evolution of the central Annapurna Range, Nepalese Himalayas, Tectonics, 15, 1264-1291, doi:10.1029/96TC01791.

Holland, T. J. B., and R. Powell (1998), An internally consistent thermodynamic data set for phases of petrological interest, J. Metamorph. Geol., 16, 309 343, doi:10.1111/j.1525-1314.1998.00140.x.

House, M. A., K. A. Farley, and D. Stockli (2000), Helium chronometry of apatite and titanite using $\mathrm{Nd}-$ YAG laser heating, Earth Planet. Sci. Lett., 183 , 365-368, doi:10.1016/S0012-821X(00)00286-7.

Indares, A., R. W. White, and R. Powell (2008), Phase equilibria modelling of kyanite-bearing anatectic paragneisses from the central Grenville Province, J. Metamorph. Geol., 26, 815-836, doi:10.1111/ j.1525-1314.2008.00788.x.

Jamieson, R. A., C. Beaumont, S. Medvedev, and M. H. Nguyen (2004), Crustal channel flows: 2. Numerical models with implications for metamorphism in the Himalayan-Tibetan orogen, J. Geophys. Res., 109, B06407, doi:10.1029/2003JB002811.

Jessup, M. J., D. L. Newell, J. M. Cottle, A. L. Berger, and J. A. Spotila (2008), Orogen-parallel extension and exhumation enhanced by denudation in the trans-Himalayan Arun River gorge, Ama Drime Massif, Tibet-Nepal, Geology, 36, 587-590, doi:10.1130/G24722A.1

Johnson, M. R. W., G. J. H. Oliver, R. R. Parrish, and S. P. Johnson (2001), Synthrusting metamorphism, cooling, and erosion of the Himalayan Kathmandu Complex, Nepal, Tectonics, 20, 394 415, doi:10.1029/2001TC900005.

Kapp, P., and J. H. Guynn (2004), Indian punch rifts Tibet, Geology, 32, 993-996, doi:10.1130/ G20689.1.

Kapp, P., M. Taylor, D. Stockli, and L. Ding (2008) Development of active low-angle normal fault systems during orogenic collapse: Insight from Tibet, Geology, 36, 7-10, doi:10.1130/G24054A.1

Kelsey, D. E., C. Clark, and M. Hand (2008), Thermobarometric modelling of zircon and monazite growth in melt-bearing systems: Examples using model metapelitic and metapsammitic granulites, J. Metamorph. Geol., 26, 199-212, doi:10.1111/ j.1525-1314.2007.00757.x.

Kohn, M. J., E. J. Catlos, F. J. Ryerson, and T. M. Harrison (2001), Pressure-temperature-time path discontinuity in the Main Central Thrust zone, central Nepal, Geology, 29, 571-574, doi:10.1130/ 0091-7613(2001)029<0571:PTTPDI >2.0.CO;2

Kohn, M. J., M. S. Wieland, C. D. Parkinson, and B. N. Upreti (2004), Miocene faulting at plate tectonic velocity in the Himalaya of central Nepal, Earth Planet. Sci. Lett., 228, 299-310, doi:10.1016/j. eps1.2004.10.007.

Kohn, M. J., M. S. Wieland, C. D. Parkinson, and B. N. Upreti (2005), Five generations of monazite in Langtang gneisses: Implications for chronology of the Himalayan metamorphic core, J. Metamorph Geol., 23, 399-406, doi:10.1111/j.1525 1314.2005.00584.x

Lee, T. Y., and L. A. Lawver (1995), Cenozoic plate reconstruction of Southeast Asia, Tectonophysics, 251, 85-138, doi:10.1016/0040-1951(95)00023-2.

Le Fort, P. (1975), Himalayas-collided range-Present knowledge of continental arc, Am. J. Sci., A275, $1-44$.
Leloup, P. H., T. M. Harrison, F. J. Ryerson, W. J. Chen, Q. Li, P. Tapponnier, and R. Lacassin (1993), Structural, petrological and thermal evolution of a Tertiary ductile strike-slip shear zone, Diancang Shan, Yunnan, J. Geophys. Res., 98, 67156743, doi:10.1029/92JB02791.

Leloup, P. H., E. Kali, N. Arnaud, G. Mahéo, E. Boutonnet, Liu X., D. Liu, H. Li, and J. Liu-Zeng (2009), Miocene $(\sim 12 \mathrm{Ma})$ transition from E-W to N-S syn-convergence normal faulting in the central Himalayas (Ama Drime range), Geophys. Res. Abstr., 11, EGU2009-9690-2001.

Leloup, P. H., G. Maheo, N. Arnaud, E. Kali, E. Boutonnet, D. Liu, Liu X., and Li H. (2010), The South Tibet detachment shear zone in the Dinggye area: Time constraints on extrusion models of the Himalayas, Earth Planet. Sci. Lett., 292, 1-16, doi:10.1016/j.eps1.2009.12.035.

Li, D., Q. Liao, Y. Yuan, Y. Wan, D. Liu, X. Zhang, S. Yi, S. Cao, and D. Xie (2003), SHRIMP U-Pb zircon geochronology of granulites at Rimana (southern Tibet) in the central segment of Himalayan Orogen, Chin. Sci. Bull., 48, 2647-2650, doi:10.1360/03wd0080.

Liu, S. W., J. J. Zhang, G. M. Shu, and Q. G. Li (2005), Mineral chemistry, P-T-t paths and exhumation processes of mafic granulites in Dinggye, southern Tibet, Sci. Ch. Ser. Earth Sci., 48, 1870-1881.

Liu, Y., W. Siebel, H. J. Massonne, and X. C. Xiao (2007), Geochronological and petrological constraints for tectonic evolution of the central Greater Himalayan Sequence in the Kharta area, southern Tibet, J. Geol., 115, 215-230, doi:10.1086/510806.

Lombardo, B., and F. Rolfo (2000), Two contrasting eclogite types in the Himalayas: Implications for the Himalayan orogeny, J. Geodyn., 30, 37-60, doi:10.1016/S0264-3707(99)00026-5.

Lombardo, B., P. Pertusati, and A. Borghi (1993), Geology and tectono-magmatic evolution of the eastern Himalaya along the Chomolungma-Makalu transect, in Himalayan Tectonics, edited by P. J. Treloar and M. P. Searle, Geol. Soc. Spec. Publ., 74, 341-355.

Ludwig, K. R. (2003), Isoplot 3.00 a geochronological toolkit for Microsoft Excel, Spec. Publ. 4, Berkeley Geochronol. Cent., Berkeley, Calif.

Macfarlane, A. M. (1993), Chronology of tectonic events in the crystalline core of the Himalaya, Langtang National Park, central Nepal, Tectonics, 12, 1004-1025, doi:10.1029/93TC00916.

Mahéo, G., P. H. Leloup, F. Valli, R. Lacassin, N. Arnaud, J. L. Paquette, A. Fernandez, L. Haibing, K. A. Farley, and P. Tapponnier (2007), Post $4 \mathrm{Ma}$ initiation of normal faulting in southern Tibet: Constraints from the Kung Co half graben, Earth Planet. Sci. Lett., 256, 233-243, doi:10.1016/j. eps1.2007.01.029.

Makovsky, Y., S. L. Klemperer, L. Y. Huang, and D. Y. $\mathrm{Lu}$ (1996), Structural elements of the southern Tethyan Himalaya crust from wide-angle seismic data Tectonics, 15, 997-1005, doi:10.1029/96TC00310.

Martin, A. J., G. E. Gehrels, and P. G. DeCelles (2007), The tectonic significance of $(\mathrm{U}, \mathrm{Th}) / \mathrm{Pb}$ ages of monazite inclusions in garnet from the Himalaya of central Nepal, Chem. Geol., 244, 1-24, doi:10.1016/j. chemgeo.2007.05.003.

McCaffrey, R., and J. Nabelek (1998), Role of oblique convergence in the active deformation of the Himalayas and southern Tibet Plateau, Geology, 26, 691694, doi:10.1130/0091-7613(1998)026<0691: ROOCIT $>2.3 . \mathrm{CO} ; 2$.

Meier, K., and E. Hiltner (1993), Deformation and metamorphism within the Main Central Thrust zone, Arun tectonic Window, eastern Nepal, in Himalayan Tectonics, edited by P. J. Treloar and M. P. Searle, Geol. Soc. Spec. Publ., 74, 511-523.

Meigs, A. J., D. W. Burbank, and R. A. Beck (1995), Middle-late Miocene ( $>10 \mathrm{Ma}$ ) Formation of the Main Boundary Thrust in the western Himalaya, Geology, 23, 423-426, doi:10.1130/0091-7613 (1995)023<0423:MLMMFO>2.3.CO;2. 
Molnar, P., and J. Stock (2009), Slowing of India's convergence with Eurasia since $20 \mathrm{Ma}$ and its implications for Tibetan mantle dynamics, Tectonics, 28 , TC3001, doi:10.1029/2008TC002271.

Molnar, P., and P. Tapponnier (1978), Active tectonics of Tibet, J. Geophys. Res., 83, 5361-5373, doi:10.1029/JB083iB11p05361.

Monsalve, G., A. Sheehan, V. Schulte-Pelkum, S. Rajaure, M. R. Pandey, and F. Wu (2006), Seismicity and one-dimensional velocity structure of the Himalayan collision zone: Earthquakes in the crust and upper mantle, J. Geophys. Res., 111, B10301, doi:10.1029/2005JB004062.

Murphy, M. A., and T. M. Harrison (1999), Relationship between leucogranites and the Qomolangma detachment in the Rongbuk Valley, south Tibet, Geology, 27, 831-834, doi:10.1130/0091-7613 (1999) $027<0831$ :RBLATQ $>2.3 . C O ; 2$

Murphy, M. A., A. Yin, P. Kapp, T. M. Harrison, C. E. Manning, F. J. Ryerson, L. Ding, and J. H. Guo 2002), Structural evolution of the Gurla Mandhata detachment system, southwest Tibet: Implications for the eastward extent of the Karakoram fault system, Geol. Soc. Am. Bull., 114, 428-447, doi: $10.1130 / 0016-7606(2002) 114<0428$ : SEOTGM $>2.0 . \mathrm{CO} ; 2$.

Nelson, K. D., et al. (1996), Partially molten middle crust beneath southern Tibet: Synthesis of project INDEPTH results, Science, 274, 1684-1688, doi:10.1126/science.274.5293.1684.

Pan, Y., and W. S. F. Kidd (1992), Nyainqentanglha Shear Zone-A late Miocene extensional detachment in the southern Tibetan Plateau, Geology, 20, 775-778, doi:10.1130/0091-7613(1992) $020<0775$ :NSZALM $>2.3 . \mathrm{CO} ; 2$.

Pandey, M. R., R. P. Tandukar, J. P. Avouac, J. Lave, and J. P. Massot (1995), Interseismic Strain Accumulation on the Himalayan Crustal Ramp (Nepal), Geophys. Res. Lett., 22, 751-754, doi:10.1029/ 94GL02971.

Pandey, M. R., R. P. Tandukar, J. P. Avouac, J. Vergne, and T. Heritier (1999), Seismotectonics of the Nepal Himalaya from a local seismic network, $J$. Asian Earth Sci., 17, 703-712, doi:10.1016/S1367-9120 (99)00034-6.

Patiño-Douce, A. E., and J. S. Beard (1996), Effects of $\mathrm{P}, f(\mathrm{O}-2)$ and $\mathrm{Mg} / \mathrm{Fe}$ ratio on dehydration melting of model metagreywackes, J. Petrol., 37, 999-1024, doi:10.1093/petrology/37.5.999.

Patiño-Douce, A. E and N. Harris (1998), Experimental constraints on Himalayan anatexis, J. Petrol., 39, 689-710, doi:10.1093/petrology/39.4.689.

Powell, R., and J. A. Evans (1983), A new geobarometer for the assemblage biotite-muscovite-chloritequartz, J. Metamorph. Geol., 1, 331-336, doi:10.1111/j.1525-1314.1983.tb00278.x.

Reche, J., and F. J. Martinez (1996), GPT: An Excel spreadsheet for thermobarometric calculations in metapelitic rocks, Comput. Geosci., 22, 775-784, doi:10.1016/0098-3004(96)00007-6.

Richards, A., T. Argles, N. Harris, R. Parrish, T. Ahmad, F. Darbyshire, and E. Draganits (2005), Himalayan architecture constrained by isotopic tracers from clastic sediments, Earth Planet. Sci. Lett., 236, 773-796, doi:10.1016/j.eps1.2005.05.034.

Roberts, M. P., and F. Finger (1997), Do U-Pb zircon ages from granulites reflect peak metamorphic conditions?, Geology, 25, 319-322, doi:10.1130/00917613(1997)025<0319:DUPZAF $>2.3 . C O ; 2$

Robinson, D. M., P. G. DeCelles, P. J. Patchett, and C. N. Garzione (2001), The kinematic evolution of the Nepalese Himalaya interpreted from Nd isotopes, Earth Planet. Sci. Lett., 192, 507-521, doi:10.1016/S0012-821X(01)00451-4.

Rolfo, F., W. McClelland, and B. Lombardo (2005), Geochronological constraints on the age of the eclogite-facies metamorphism in the eastern Himalaya, in Geologie Alpine, Mem. H.S. 20th HimalayaKarakorum-Tibet Workshop, 44, 170.

Royden, L. H., B. C. Burchfiel, R. W. King, E. Wang, Z. L. Chen, F. Shen, and Y. P. Liu (1997), Surface deformation and lower crustal flow in eastern Tibet, Science, 276, 788-790, doi:10.1126/science.276. 5313.788

Rubatto, D., I. S. Williams, and I. S. Buick (2001), Zircon and monazite response to prograde metamorphism in the Reynolds Range, central Australia, Contrib. Mineral. Petrol., 140, 458-468, doi:10.1007/PL00007673.

Schaltegger, U., C. M. Fanning, D. Gunther, J. C. Maurin, K. Schulmann, and D. Gebauer (1999), Growth, annealing and recrystallization of zircon and preservation of monazite in high-grade metamorphism: Conventional and in-situ U-Pb isotope, cathodoluminescence and microchemical evidence, Contrib. Mineral. Petrol., 134, 186-201, doi:10.1007/s004100050478.

Schelling, D. (1992), The tectonostratigraphy and structure of the eastern Nepal Himalaya, Tectonics, 11, 925-943, doi:10.1029/92TC00213.

Schelling, D., and K. Arita (1991), Thrust tectonics, crustal shortening, and the structure of the far-eastern Nepal Himalaya, Tectonics, 10, 851-862, doi:10.1029/91TC01011.

Schiotte, L., W. Compston, and D. Bridgwater (1989), Ion probe $\mathrm{U}-\mathrm{Th}-\mathrm{Pb}$ zircon dating of polymetamorphic orthogneisses from northern Labrador, Canada, Can. J. Earth Sci., 26(8), 1533-1556, doi:10.1139/e89-131.

Schulte-Pelkum, V., G. Monsalve, A. Sheehan, M. R. Pandey, S. Sapkota, R. Bilham, and F. Wu (2005), Imaging the Indian subcontinent beneath the Himalaya, Nature, 435, 1222-1225, doi: 10.1038 /nature 03678 .

Searle, M. P. (2007), Geological map of the Mount Everest-Makalu region Nepal-South Tibet Himalaya, scale 1:100 000, Dep. of Earth Sci., Oxford Univ., Oxford, U. K

Searle, M. P., S. R. Noble, A. J. Hurford, and D. C. Rex (1999), Age of crustal melting, emplacement and exhumation history of the Shivling leucogranite, Garhwal Himalaya, Geol. Mag., 136, 513-525, doi:10.1017/S0016756899002885.

Simpson, R. L., R. R. Parrish, M. P. Searle, and D. J. Waters (2000), Two episodes of monazite crystallization during metamorphism and crustal melting in the Everest region of the Nepalese Himalaya, Geology, 28, 403-406, doi:10.1130/0091-7613(2000) $28<403$ :TEOMCD $>2.0 . \mathrm{CO} ; 2$.

Szulc, A. G., et al. (2006), Tectonic evolution of the Himalaya constrained by detrital ${ }^{40} \mathrm{Ar}^{39}{ }^{39} \mathrm{Ar}, \mathrm{Sm}-$ $\mathrm{Nd}$ and petrographic data from the Siwalik foreland basin succession, SW Nepal, Basin Res., 18, 375391, doi:10.1111/j.1365-2117.2006.00307.x.

Tapponnier, P., J. L. Mercier, R. Armijo, T. L. Han, and J. Zhou (1981), Field evidence for active normal faulting in Tibet, Nature, 294, 410-414, doi:10.1038/294410a0

Tapponnier, P., Z. Q. Xu, F. Roger, B. Meyer, N. Arnaud, G. Wittlinger, and J. S. Yang (2001), Geology-Oblique stepwise rise and growth of the Tibet Plateau, Science, 294, 1671-1677, doi:10.1126/science.105978.

Thompson, A. B., and J. A. D. Connolly (1995), Melting of the continental crust: Some thermal and petrological constraints on anatexis in continental collision zones and other tectonic settings, J. Geophys. Res., 100, 15,565-15,579, doi:10.1029/ 95JB00191.

Vance, D., and N. Harris (1999), Timing of prograde metamorphism in the Zanskar Himalaya, Geology, 27, 395-398, doi:10.1130/0091-7613(1999) $027<0395$ :TOPMIT $>2.3$.CO; 2 .

Vance, D., and E. Mahar (1998), Pressure-temperature paths from P-T pseudosections and zoned garnets:
Potential, limitations and examples from the Zanskar Himalaya, NW India, Contrib. Mineral. Petrol. 132, 225-245, doi:10.1007/s004100050419.

Vannay, J. C., Z. D. Sharp, and B. Grasemann (1999), Himalayan inverted metamorphism constrained by oxygen isotope thermometry, Contrib. Mineral. Petrol., 137, 90-101, doi:10.1007/s004100050584.

Vavra, G., R. Schmid, and D. Gebauer (1999), Internal morphology, habit and $\mathrm{U}-\mathrm{Th}-\mathrm{Pb}$ microanalysis of amphibolite-to-granulite facies zircons: Geochronology of the Ivrea Zone (Southern Alps), Contrib. Mineral. Petrol., 134, 380-404, doi:10.1007/ s004100050492.

Vielzeuf, D., and J. D. Clemens (1992), The fluidabsent melting of phlogopite + quartz: Experiments and models, Am. Mineral., 77, 1206-1222.

Vielzeuf, D., and J. R. Holloway (1988), Experimenta determination of the fluid-absent melting relations in the pelitic system, Contrib. Mineral. Petrol., 98, 257-276, doi:10.1007/BF00375178.

Vielzeuf, D., and J. M. Montel (1994), Partial melting of metagreywackes. Part I. Fluid-absent experiments and phase relationships, Contrib. Mineral. Petrol., 117, 375-393, doi:10.1007/BF00307272.

Viskupic, K., and K. V. Hodges (2001), Monazitexenotime thermochronometry: Methodology and an example from the Nepalese Himalaya, Contrib. Mineral. Petrol., 141, 233-247.

Visonà, D., and B. Lombardo (2002), Two-mica and tourmaline leucogranites from the Everest-Makalu region (Nepal-Tibet). Himalayan leucogranite genesis by isobaric heating?, Lithos, 62, 125-150, doi:10.1016/S0024-4937(02)00112-3.

Wager, L. R. (1937), The Arun River drainage pattern and the rise of the Himalaya, Geol. J., 89, 239-250.

Walker, J. D., M. W. Martin, S. A. Bowring, M. P. Searle, D. J. Waters, and K. V. Hodges (1999), Metamorphism, melting, and extension: Age constraints from the High Himalayan Slab of southeast Zanskar and northwest Lahaul, J. Geol., 107, 473495, doi:10.1086/314360.

Webb, A. A. G., A. Yin, T. M. Harrison, J. Celerier, and W. P. Burgess (2007), The leading edge of the Greater Himalayan Crystalline complex revealed in the NW Indian Himalaya: Implications for the evolution of the Himalayan orogen, Geology, 35, 955-958, doi:10.1130/G23931A.1.

Yin, A. (2000), Mode of Cenozoic east-west extension in Tibet suggesting a common origin of rifts in Asia during the Indo-Asian collision, J. Geophys. Res. 105, 21,745-21,759, doi:10.1029/2000JB900168.

Zhang, J. J., and L. Guo (2007), Structure and geochronology of the southern Xainza-Dinggye rift and its relationship to the South Tibetan Detachment System, J. Asian Earth Sci., 29, 722-736, doi:10.1016/j.jseaes.2006.05.003.

N. Arnaud, Géosciences Montpellier, Université de Montpellier 2, Cc.060, P1. E. Bataillon, F-34095 Montpellier CEDEX 05, France.

E. Boutonnet, P. H. Leloup, and G. Mahéo, LST, UMR 5570, Université de Lyon, ENS Lyon, UCB Lyon1, CNRS, bat Géode, 43 Bd du 11 Novembre 1918, F-69622 Villeurbanne CEDEX, France. (herve. leloup@univ-lyon1.fr)

E. Kali and J. Van der Woerd, Institut de Physique du Globe de Strasbourg, UMR 7516, CNRS, UDS/ EOST, 5 rue Rene Descartes, F-67084 Strasbourg, France.

J. Liu-Zeng and X. Liu, Institute of Tibetan Platea Research, Chinese Academy of Sciences, 18 Shuang Qing Rd., Beijing 100085, China.

H. Li and D. Liu, Laboratory of Continental Dynamics, Institute of Geology, CAGS, 26 Baiwanzhuang Rd., Beijing 100037, China. 